\title{
WestVirginiaUniversity
}

THE RESEARCH REPOSITORY @ WVU

Graduate Theses, Dissertations, and Problem Reports

2015

\section{Three Essays on Remittances, Institutions, and Economic Development}

\author{
Durga Gautam
}

Follow this and additional works at: https://researchrepository.wvu.edu/etd

Part of the Business Law, Public Responsibility, and Ethics Commons, Corporate Finance Commons, and the Finance and Financial Management Commons

\section{Recommended Citation}

Gautam, Durga, "Three Essays on Remittances, Institutions, and Economic Development" (2015).

Graduate Theses, Dissertations, and Problem Reports. 5651.

https://researchrepository.wvu.edu/etd/5651

This Dissertation is protected by copyright and/or related rights. It has been brought to you by the The Research Repository @ WVU with permission from the rights-holder(s). You are free to use this Dissertation in any way that is permitted by the copyright and related rights legislation that applies to your use. For other uses you must obtain permission from the rights-holder(s) directly, unless additional rights are indicated by a Creative Commons license in the record and/ or on the work itself. This Dissertation has been accepted for inclusion in WVU Graduate Theses, Dissertations, and Problem Reports collection by an authorized administrator of The Research Repository @ WVU.

For more information, please contact researchrepository@mail.wvu.edu. 


\title{
Three Essays on Remittances, Institutions, and Economic Development
}

\section{Durga Gautam}

\author{
Dissertation submitted \\ to the College of Business and Economics \\ at West Virginia University \\ in partial fulfillment of the requirements for the degree of \\ Doctor of Philosophy \\ in \\ Economics
}

\begin{abstract}
Feng Yao, Ph.D., Chair
Stratford Douglas, Ph.D.

Arabinda Basistha, Ph.D.

Andrew Young, Ph.D.

Philip Michelbach, Ph.D.

Department of Economics
\end{abstract}

Morgantown, West Virginia

2015

Keywords: Remittances, institutions, corruption, financial inclusion, business regulations, nonparametric regression, consumption expenditure, public goods

Copyright 2015 Durga Gautam 


\section{Abstract}

\section{Three Essays on Remittances, Institutions, and Economic Development}

\section{Durga Gautam}

Does the inflow of remittances affect the quality of institutions in the recipient countries? This question is important because economists have stressed that good economic institutions, particularly those in the public sector, are instrumental for economic development and growth. The literature on remittances, however, does not document a thorough analysis and compelling evidence of the relationship between these private financial transfers and institutional quality. Unlike other kinds of international capital flows, remittances inflows are not mediated by the government of recipient countries. Remittances are not taxed directly and so are not a source of revenue for the government. Then a natural question first arises, namely what mechanism explains the relationship, if any, between remittances and the quality of domestic governance?

Given the substantial size and impressive growth of remittances to many developing countries, we investigate the effects of these income transfers on domestic institutions. Studies show that remittances are most likely to influence the incentives faced by households and the government. So inflows of remittances can be a potential factor to affect institutional quality through their effects on private and public investment. In this dissertation, we examine the effects of remittances on political institutions, financial inclusion, and entrepreneurial environment in the recipient countries. We use either cross-sectional or panel data depending on the particular measure of institutional quality. Although we employ both parametric and nonparametric methods, we primarily focus on recently advanced kernel regression that allows nonlinearity and heterogeneity in partial effects of remittances. The results of our empirical study provide strong evidence of a causal relationship between remittances and the quality of domestic institutions. The rise in remittances, however, is not found to have a uniform impact on institutional quality across all countries or over time. 


\section{Acknowledgments}

First of all, I owe a debt of gratitude to Dr. Feng Yao for his guidance, patience, and supports throughout my dissertation and during my entire graduate coursework. He read virtually every section of my dissertation, usually at an early stage, and provided many valuable comments and suggestions. I have had no courses in nonparametric econometrics, but now I find myself competent in applying nonparametric methods and skills of R programming language to empirical research. Mastering these tools and their applications to my research were not possible without his assistance, encouragement, and strict supervision.

I am also indebted to Dr. Stratford Douglas for his great mentorship during my graduate studies. He reminded me the value of tolerance on the path to become an independent researcher and in the profession to feel a sense of purpose. Similarly, I would like to acknowledge my debt to Dr. Brian Cushing and Dr. Arabinda Basistha for their invaluable guidance regarding research and academic challenges.

I am grateful to Dr. Andrew Young for his constructive comments and suggestions that have materially improved the final version of my dissertation. I am thankful to Dr. Philip Michelbach for his useful comments. I would like to sincerely thank all professors in the Department of Economics at WVU who have taught me and provided guidance on my studies. Also, my deep appreciation goes to Dr. Clifford Hawley who provided me with ample opportunities for teaching. I am extremely grateful to Ms. Karen Smith for her great supports with administrative issues.

It is always wonderful to look back and see what I had during my graduate program at WVU. I would like to express my sincere thanks to Serkan Karadas, Zheng Tian, Jorida Papakroni, Tammy Schlosky, Kirill Temlyakov, Martin Montero, Hossein Radmard, and Hernan Botero for their significant assistance and guidelines on teaching and research.

At the center of this endeavor, I much owe to my wife, Tanka Dahal, for her precious supports in my graduate study by taking care of my two children, Sarthak and Sarika, and of all household affairs. Finally, I would like to offer this manuscript as a tribute to my parents who inspired me with honesty, faith, and compassion. 


\section{Contents}

$\begin{array}{ll}\text { Acknowledgments } & \text { iii }\end{array}$

Table of Contents $\quad$ iv

List of Figures $\quad$ vi

List of Tables

1 Introduction $\quad 1$

1.1 Remittances: A brief outline .................... . . 3

1.2 Theories on remittances and institutions . . . . . . . . . . . . . 5

1.3 An overview of the dissertation . . . . . . . . . . . . . 8

2 Remittances and Governance: Does the Government Free Ride? 11

2.1 Introduction . . . . . . . . . . . . . . . . . . . . . 11

2.2 Empirical methodology . . . . . . . . . . . . . . . . . 20

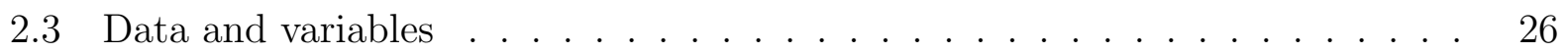

2.4 Empirical findings . . . . . . . . . . . . . . . . . . 28

2.4.1 Parametric estimates . . . . . . . . . . . . . . . . 28

2.4.2 Nonparametric estimates . . . . . . . . . . . . . . . . . 31

2.5 Concluding remarks . . . . . . . . . . . . . . . . . . . . . . . . 42

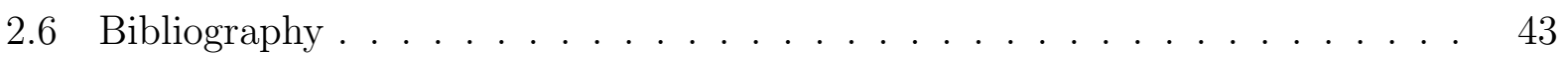

2.7 Appendix . . . . . . . . . . . . . . . . . . . . . . . 49 
3 Do Remittances Promote Financial Inclusion? 60

3.1 Introduction . . . . . . . . . . . . . . . . . . . . . . 60

3.2 Literature review . . . . . . . . . . . . . . . . . . . 63

3.3 Empirical methodology and data . . . . . . . . . . . . . 66

3.4 Empirical findings . . . . . . . . . . . . . . . . . . . . . . . . . . . . . . . 69

3.5 Concluding remarks . . . . . . . . . . . . . . . . 73

3.6 Bibliography . . . . . . . . . . . . . . . . . . . . . . 75

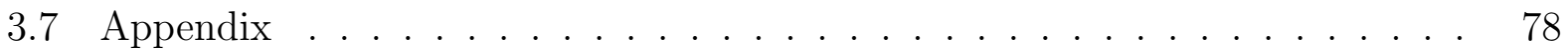

4 Do Remittances Enhance the Ease of Starting a Business? 94

4.1 Introduction . . . . . . . . . . . . . . . . . . . . 94

4.2 Literature review $\ldots \ldots \ldots \ldots$

4.3 Empirical methodology . . . . . . . . . . . . . . . . . . . . . . . 102

4.4 Interpretation of parameter estimates . . . . . . . . . . . . 105

4.5 Data and variables . . . . . . . . . . . . . . . . . . 107

4.6 Empirical findings . . . . . . . . . . . . . . . . . . . . . . . 108

4.7 Concluding remarks . . . . . . . . . . . . . . . . . . . . . . 111

4.8 Bibliography . . . . . . . . . . . . . . . . . . . . . . . . . . 112

4.9 Appendix . . . . . . . . . . . . . . . . . . . . . . . 114

5 Conclusion, Policy Implications, and Future Research $\quad 117$

5.1 Summary . . . . . . . . . . . . . . . . . . . . . 117

5.2 Policy implications . . . . . . . . . . . . . . . . . . . . . . . . 119

5.3 Future research . . . . . . . . . . . . . . . . . . . . 120 


\section{List of Figures}

1.1 Financial resources flows to developing countries . . . . . . . . . . . . 3

2.1 Remittances (\% of GDP, Remitgdp) and the ratio of household consumption expenditure to government consumption expenditure (Cratio, the upper panels). Consumption expenditures ratio (Cratio) and government control of corruption (Ccorrup, the lower panels), 2010-2012. . . . . . . . . . .

2.2 Remittances (\% of GDP, Remitgdp) and the ratio of household consumption expenditure to government consumption expenditure (Cratio) for a set of countries, 2002-2012. . . . . . . . . . . . . . . . 16

2.3 Consumption expenditures ratio (Cratio) and government corruption (Ccorrup) for the same set of countries as in Figure 2.2, 2002-2012. . . . . . . .

2.4 Kernel density plots of estimates using local constant estimator for the regression model of corruption. Note: 'Cratio' stands for the consumption expenditures ratio while some plots are excluded. . . . . . . . . . . . 


\section{List of Tables}

2.1 OLS and panel estimates for parametric specifications. . . . . . . . . . . . 49

2.2 Remittances and the quality of governance: parametric panel estimates. . . . 50

2.3 Parametric estimates with 3 -year average of explanatory variables. ${ }^{\dagger} \ldots$. . . 51

2.4 Remittances, household and government consumption expenditures, and consumption expenditures ratio: ${ }^{1}$ parametric panel estimates. . . . . . . . . . 52

2.5 Bandwidths for regressors in the model for the quality of governance. UB is the upper bound for a regressor. LC and LL represent local constant and local linear estimators respectively. . . . . . . . . . . . . . . .

2.6 Nonparametric local kernel estimates ${ }^{1}$ from the models of quality of governance. Estimates corresponding to the 25th, 50th, and 75th percentiles of the estimated parameter distribution are reported. (labeled as Q1, Q2, and Q3.)

2.7 Nonlinearity in remittances and consumption expenditures ratio. Nonapametric local kernel estimates ${ }^{1}$ for consumption expenditures ratio and remittances from the models of quality of governance. Estimates corresponding to the 25th, 50th, and 75th percentiles of the estimated parameter distribution are reported. (labeled as Q1, Q2, and Q3.) . . . . . . . . . 55

2.8 Remittances, household and government consumption expenditures, and consumption expenditures ratio: Nonparametric local kernel estimates ${ }^{1}$. Estimates corresponding to the $25 \mathrm{th}, 50 \mathrm{th}$, and 75 th percentiles of the estimated parameter distribution are reported. (labeled as Q1, Q2, and Q3.) . . . .

2.9 Nonparametric percentile estimates for remittances from regressions in Table 2.8 , but at some specific ranges of the coefficient distribution. . . . . . . 
2.10 Nonparametric partial estimates for remittances from the regression model of government consumption expenditure in Table 2.8, obtained by splitting remittances data values into four groups by its quartiles. Reported estimates, denoted by Q1, Q2, and Q3, are the quartile values for each of the four groups. 57

2.11 Local constant bandwidths ${ }^{1}$ for the instrumental variables (IV) estimation. 58

2.12 Partial effects estimates from the instrumental variables (IV) estimation ${ }^{1}$ for consumption expenditures ratio. Estimates corresponding to the 25th, 50th, and 75th percentiles of the estimated parameter distribution (labeled as Q1, Q2, and Q3) are reported. The partial effects are also presented by splitting the levels of the consumption expenditures ratio by its median value. . . . . 58

2.13 Summary Statistics . . . . . . . . . . . . . . . . . . 59

3.1 Description of the indicators of financial inclusion and other explanatory variables, and their data sources. . . . . . . . . . . . . . . . . 78

3.2 Semiparametric Partially Linear Model estimates. Dependent Variable is the composite index of financial inclusion, country-level. ${ }^{*}$. . . . . . . . . 79

3.3 Semiparametric Partially Linear Model estimates. Dependent Variable is the index of financial inclusion for account at a formal financial institution,

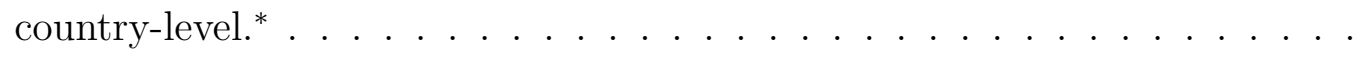

3.4 Semiparametric Partially Linear Model estimates. Dependent Variable is the index of financial inclusion for saved at a formal financial institution, country-

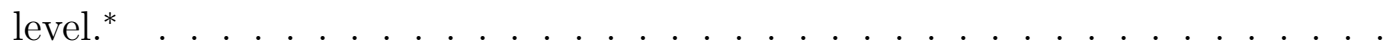

3.5 Semiparametric Partially Linear Model estimates. Dependent Variable is the composite index of financial inclusion, rural-sector.* . . . . . . . . . .

3.6 Semiparametric Partially Linear Model estimates. Dependent Variable is the index of financial inclusion for account at a formal financial institution, ruralsector. $^{*} \ldots \ldots \ldots \ldots \ldots \ldots \ldots$

3.7 Semiparametric Partially Linear Model estimates. Dependent Variable is the index of financial inclusion for saved at a formal financial institution, rural-

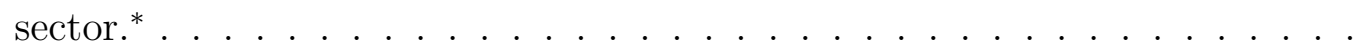


3.8 Semiparametric Partially Linear Model estimates. Dependent Variable is the composite index of financial inclusion, urban-sector. ${ }^{*} \ldots \ldots . . . .$.

3.9 Semiparametric Partially Linear Model estimates. Dependent Variable is the index of financial inclusion for account at a formal financial institution, urban-

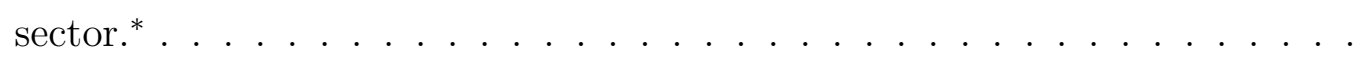

3.10 Semiparametric Partially Linear Model estimates. Dependent Variable is the index of financial inclusion for saved at a formal financial institution, urban-

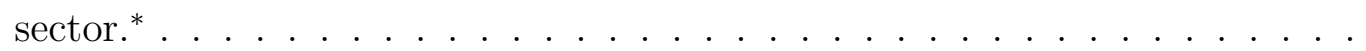

3.11 Remittances and financial inclusion: OLS estimates from linear parametric models (country-level). . . . . . . . . . . . . . . . . 88

3.12 Remittances and financial inclusion: OLS estimates from linear parametric models (rural-sector). . . . . . . . . . . . . . . . . 89

3.13 Remittances and financial inclusion: OLS estimates from linear parametric models (urban-sector). . . . . . . . . . . . . . . . . . 90

3.14 Remittances (in first-differences) and financial inclusion: OLS estimates from linear parametric models (country-level). . . . . . . . . . . . . . 91

3.15 Remittances (in first-differences) and financial inclusion: OLS estimates from linear parametric models (rural-sector) . . . . . . . . . . . . . . . . 92

3.16 Remittances (in first-differences) and financial inclusion: OLS estimates from linear parametric models (urban-sector). . . . . . . . . . . . .

4.1 Remittances and starting a business: Pooled OLS, Random-effects (RE), and Beta (ML) estimates. . . . . . . . . . . . . . . . . . 114

4.2 Remittances and time required to start a business: Pooled OLS and Randomeffects (RE) estimates. . . . . . . . . . . . . . . . 115

4.3 Summary Statistics ${ }^{\dagger} \ldots \ldots \ldots \ldots \ldots$ 


\section{Chapter 1}

\section{Introduction}

The massive increase in cross-border movement of nationals has led to a remarkable growth of global remittances over the last three decades. Remittances now exceed receipts from export earnings and financial inflows of foreign direct investment for many countries (World Bank, 2014). As a key resource of foreign capital in the balance of payments, remittances have outpaced official development assistance and remained more stable than private debt and portfolio equity flows over past several years (see Kapur and McHale, 2005; International Monetary Fund, 2010). Though the effects of global trade and international capital flows on domestic institutions and national policy choices have been studied extensively in the literature (e.g. Quinn, 1997; Rodrik, 1998; Garrett, 2001; Rudra, 2002; Sala-i-Martin and Subramanian, 2003; Rickard, 2012), no such scrutiny has been witnessed with regard to international remittance flows.

Recently, researchers have come to recognize remittances as one of the dominant sources

of income and foreign exchange for many developing countries. The growing importance of remittances has stimulated a great deal of discussion among scholars and policymakers. In particular, remittances studies have been taken up by the officials of multilateral institutions, by those working with non-governmental organizations and on behalf of migrant communities, and by social scientists including development economists and anthropologists (Grabel, 
2008). From macroeconomic perspective, new growth theories have profoundly altered the direction for research on the impact of remittances. While previous research was centered on the short-run effects, focus gradually shifted to long-run considerations, notably the role of remittances on recipient countries' economic growth and long-run performance (Rapoport and Docquier, 2004). With this new perspective, and since the positive effect of modern institutions on economic development has been an established empirical proposition, some researchers have begun to highlight and investigate the relationship between remittances inflows and domestic institutions in the context of developing countries. This dissertation research attempts to contribute to this aspect of literature on remittances.

There is no reason to disagree that remittances enhance the resource base for both recipient households as well as the recipient country government. Remittances can be expected to increase consumption as well as investment expenditure in the recipient countries. Several studies show that remittances reduce poverty, increase investment in education and healthcare, foster financial development and entrepreneurship, and boost economic growth. But given that remittances are purely private familial transfers, most of these favorable outcomes appear to come from the motivation and financial activities of households, and not directly from the enhanced role of the government in the economy.

Then, the crucial questions are the following: are the governments in the recipient countries induced to curtail their expenditures on public goods and services as households receive much in remittances? Do remittances deteriorate the quality of domestic institutions, including the ones in the public sector? As remittances are found to enhance financial resources of households, do they promote financial inclusion in the recipient economies? Furthermore, by effecting both suppliers and demanders of financial services, do remittances help prosper entrepreneurial environment? In this dissertation, we principally address these relevant but relatively ignored issues in the remittances literature. We do so by conducting empirical studies while we emphasize the use of recently advanced econometric approaches, including nonparametric kernel regression methods. 


\subsection{Remittances: A brief outline}

What makes remittances a matter of particular concern to policymakers? Why do these private transfers deserve scholarly attention? The idea that remittances have become a major form of international capital flows have fundamentally shifted academicians' attention from other forms of capital flights to remittances flows. Also, as remittances differ from other flows in key respects, their potential macroeconomic impacts on the recipient economies could be largely different. This is likely to add a new development perspective to the policy-making process in the context of developing countries.

We now briefly outline the major characteristics of remittances. The first impression one receives from remittances literature is of the large absolute size and growth of remittances during the last three decades. Remittances have become a significant source of external financing for developing countries, emerging as their second largest source of net financial flows over the past two decades. The total volume of remittances to developing countries in the mid-1990s was US\$50 billion. This size increased to US\$125.8 billion in 2004, to US $\$ 251$ billion in 2007, and to US $\$ 401$ billion in 2012. Remittances to developing countries are projected to reach US $\$ 454$ billion in 2015. Global remittances flows, including flows to higher-income countries, are expected to follow a similar pattern, rising from US $\$ 582$ billion in 2014 to US\$608 billion in 2015. (World Bank, 2008, 2014; McHale and Kapur, 2005).

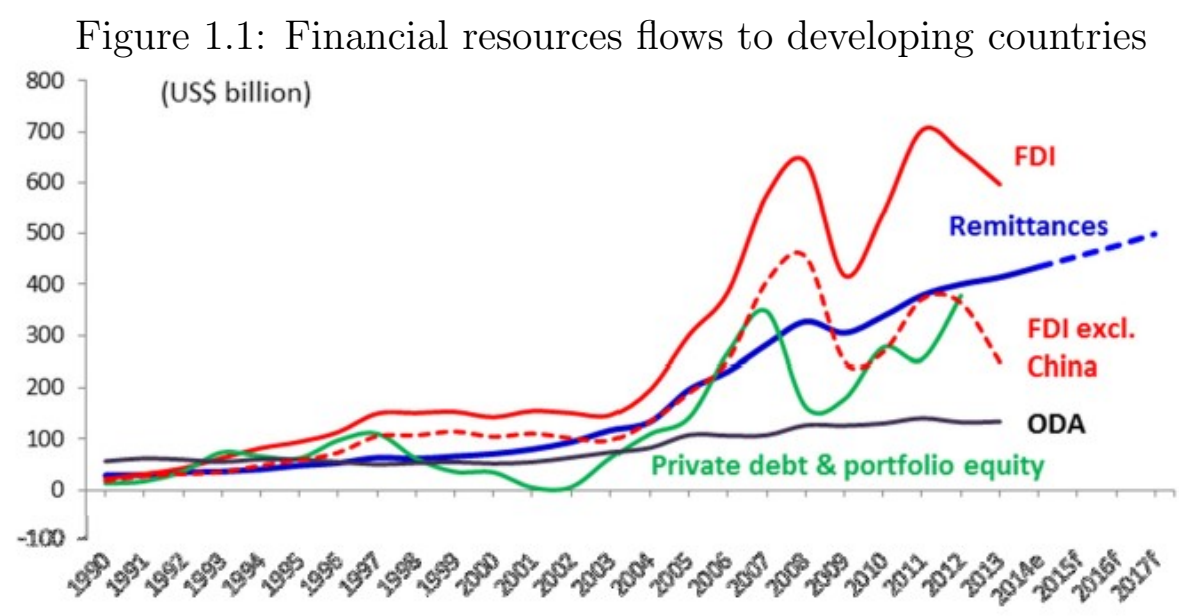

Source: Migration and Development Brief, 2014, World Bank 
In terms of their significance in the balance of payments, workers' remittances (a major part of aggregate remittances) exceed both official aid and non-FDI private capital inflows to developing countries. They are consistently trended up since 1998 up to date, except during 2006-2007. Figure 1.1 presents a comparative graphical picture of remittances and other international capital flows to developing countries for the last fifteen years. In 2013, remittances were more than three times larger than official development assistance (ODA). Moreover, workers' remittances have displayed much less variability than other balance of payments flows. Remittance flows are also significantly larger than total foreign direct investment to developing countries, excluding China. As remittances are a more stable component of receipts in the current account, they reliably bring in foreign currency that helps sustain the balance of payments and dampen gyrations (World Bank, 2008).

Overall, examination of the stylized facts based on the aggregate quantity of workers' remittances reveals remittances' relative global macroeconomic importance. Flows of workers' remittances have been growing consistently over time and now represent the second-largest balance of payments inflow to developing countries. Their relative stability versus that of other inflows to developing countries may provide additional macroeconomic benefits in terms of reduced volatility of output and consumption. These stylized facts hold with cross-country remittances data as well as with an aggregate series (Chami et al., 2008).

We have observed that remittances have grown rapidly in absolute terms, their growth is significant relative to other forms of financial flows, and they have emerged as the most stable source of financial flows that is proven to be unaffected by economic and political shocks. There are still other three characteristics of remittances that deserve special attention. First, remittances are "unrequited transfers" means that unlike other financial flows such as debt and equity flows, there are no counter claims by the sender, such as principal repayments and interest charges in the case of debt flows and profit repatriations in the case of equity flows. So, if one is interested in the financial bottom line, remittances were clearly the most important source of net foreign exchange flows to developing countries (Kapur and 
McHale, 2005). Second, remittances are counter-cyclical meaning that they tend to rise during economic downturns. This contrasts with other international private flows that tend to be strongly pro-cyclical. This makes remittances a form of self-insurance in developing countries. Finally, remittances are purely private non-market familial transfers that bypass the state and official aid bureaucracies. This attribute is particularly important to skeptics of the state and aid bureaucracies. As several controversies remain regarding other types of international capital flows, remittances flows are becoming an increasingly important part of the financial landscape of many developing countries (Grabel, 2008).

\subsection{Theories on remittances and institutions}

A survey of literature on remittances shows that most studies in remittances tend to be rather narrow and microeconomic in scope. These studies have remained unable to discern remittances within a broader political economy context. Only a few researchers have attempted to analyze the effects of remittances from a more macroeconomic perspective. In the 1970s and 1980s, this line of research was centered on the short-run effects of remittances, mainly within the framework of static trade models. But once new growth theories were advanced, the direction of research on the impact of remittances have been profoundly altered. The focus gradually shifted to long-run considerations, notably the role of remittances in dynamics of inequality, finance, entrepreneurship, and development (Djajic, 1986; Barham and Boucher, 1998; El-Sakka and McNabb, 1999; Woodruff and Zenteno, 2001; Ratha, 2003; Rapoport and Docquier, 2004; Grabel, 2008; Yang, 2011).

Researchers consider remittances as mostly altruistic in nature and take remittance transfers as gifts, grants or donations. The obvious motivation to remit is simply to care of those left behind: spouses, children, parents, and members of larger kinship and social circles (Rapaport and Docquier, 2004; United Nations Development Program, 2011). However, the government response to such philanthropic supports at national level can shrink the size 
of public services. Remittances may reduce the role of insurer of last resort often played by governments in developing countries (Ebeke, 2011). Kapur and Singer (2006) conduct an empirical analysis that explicitly shows that inflow of remittances reduces government spending in developing countries.

Some scholars consider the inflow of remittances as a form of economic rent (see Ross 2001; Kapur and McHale, 2005). Kapur and McHale argue that remittances constitute a form of rents at the national level. They discuss that governments may remain reluctant to devise institutional reforms in favor of growing remittance inflows. It is because exporting products requires painstaking effort to build the institutions and infrastructure but exporting people, on the other hand, occurs in most cases by default rather than by design.

The relationship between the receipt of worker' remittances and institutional quality is not as straightforward, and is considered as a complex and overlooked phenomenon. Political incentives in less democratic regimes tend to substitute resources from the provision of public goods to the supply of patronage (e.g. corruption) to derive greater utility (Ahmed, 2013). Ahmed shows that governments in less democratic, non-oil producing Muslim countries are found to optimally choose to reduce their provision of welfare goods as households receive more remittances. The results indicate that a one standard deviation increase in remittances raises corruption by 1.5 index points (on a 6-point scale), thereby deteriorating the quality of governance.

Regarding the impact of remittances on state behavior, Grabel (2008) opines that governments throughout the developing world have dismantled long-standing programs that provided at least some assistance to small firms and agriculturalists. State support for education and public health has also been curtailed radically. So it seems possible that remittances will allow countries to ignore the social and economic needs of their desperate regions and communities. It is, therefore, important to investigate whether remittances create a form of what we can term a "public moral hazard" on the part of developing country governments. 
Abdih at al. (2012) empirically verify that remittances are curse and cause a decline in the quality of political institutions. They develop a model of public goods provision in the presence of non-taxable remittances to show how remittances can lead to increasing share of funds for the government's own purposes diverted from public goods provision, even though remittances do not provide a direct source of revenue for the government. They argue that remittances act as a buffer between the government and its citizens and, therefore, give rise to a moral hazard problem. This leads the government to free ride and expropriate more resources for its own purposes, rather than channelizing these resources to the provision of public services.

Besides political institutions, there are few other institutional dimensions that remittance scholars have paid attention but to a little extent. These dimensions encompass financial inclusion, and business regulations and entrepreneurial environment in the recipient countries (Ashby and Seck, 2012; Anzoategui et al., 2013). Financial inclusion is the process that ensures people in a country have access to the financial services and products offered by the formal financial institutions. On the supply side, financial inclusion requires the existence of a sound financial system operated under an effective regulatory framework. In such environment, appropriate financial products and services could be collectively offered to all segments of the population within an economy. In most developing countries, however, financial services are only available to a minority of population. Mainstream for-profit financial institutions have largely ignored the segment of the market that includes the low income and poor households, as well as small- and medium-sized enterprises, often called the "missing middle"(United Nations, 2006).

The studies show that formal financial institutions in developing countries have turned their limited attention away from small business and agriculture and toward the kinds of speculative activities that have flourished in the era of financial liberalization. Therefore, formal financial institutions have also been released of their state-mandated obligations to provide support to small business and agriculture. It is likely that financial institutions 
may continue to ignore the social and economic needs of their most desperate regions and communities. On the other hand, it is also plausible that efforts to capture the blooming remittance market will eventually cause formal financial institutions to respond to their small customers (Grabel, 2008).

There is also no consensus regarding the effects of remittances on entrepreneurship, but no studies explicitly examine its impacts on business environment. Some empirical studies indicate a positive relationship between remittances and domestic investment (e.g., Woodruff and Zenteno, 2001) while others find a negative outcomes (e.g., Chami et al., 2003). A remittance-receiving country's state of financial development may cause remittance receipts to have an important influence on the domestic entrepreneurial activities. When a country's domestic financial system is poorly developed, a large number of households are rationed out of formal credit markets, because the cost of providing credit to them is prohibitively high. Such households are therefore unable to initiate business endeavors. The arrival of remittances allows them to undertake these projects (Chami et al., 2008).

In this dissertation, in addition to the impact of remittances on governance, we explore the relationship between remittances and financial inclusion, and between remittances and entrepreneurial environment. We investigate whether the inflow of remittances serve as a means to promote financial inclusion and whether it enhances the level of entrepreneurial environment in the recipient countries.

\subsection{An overview of the dissertation}

We begin the study of remittances and its potential impact on institutional quality by first addressing the following question: through what channel and to what extent does the inflow of remittances affect the quality of governance in the recipient countries? Recent studies suggest that a rise in remittances reduces public goods provision. Scholars generally agree that remittances increase consumption expenditure of the recipient households. In Chap- 
ter 2, we try to combine these two strands of literature and investigate whether inflows of remittances help or hurt the quality of domestic governance. This chapter identifies remittances as a potential factor to affect the incentives faced by households and the government in remittance-receiving economies. With respect to household behavior, our results indicate that a rise in remittances is associated with an increasing demand for private goods but a decreasing share of public goods in household consumption. Concerning government motivation, we find a significant negative association between remittances and government consumption expenditure. This critical result implies that remittances induce the government to substitute the provision of public goods for remittances. Our empirical study, therefore, provides the evidence of governmental free-riding on public goods provision in the presence of remittances. Using recently advanced kernel regression methods, we find that this substitution of resources occurs in a nonlinear fashion across countries; and leads to higher government corruption, deterioration of rule and law, and inferior regulatory quality; thereby causing a loss in public welfare.

In Chapter 3, we examine the impact of remittances on financial inclusion. The role of inclusive finance is crucial for development as the limited access to finance for the large segment of population prevents them from integrating into the economy. We analyze whether remittances affect the demand for deposit instruments and the extent of using deposit instruments in the recipient countries.

By using cross-sectional data for 2011 (for which the financial inclusion data is available), we estimate cross-country regression models by controlling key economic, social, and infrastructural characteristics. We employ semiparametric partially linear model (PLM) to allow nonlinearity and heterogeneity in partial effects of remittances on financial inclusion. We also present baseline results by estimating linear parametric versions of the PLMs in levels and in first-differences of remittances. The results show that remittances have a significant negative impact on the use of savings instruments, but have no impact on the demand for such instruments. These results continue to hold once the data are disaggregated at the 
rural level. Such findings do not hold for the urban sector, however. These findings clearly suggest that the rural sector has been facing the deficiency of financial infrastructures across countries, and most of the people who have been migrated from the rural regions are still unable to access and use financial products and services offered by the formal financial institutions. Instead, persistent remittances inflows may protect recipient households from financial risks by ensuring them against future income shocks, such as those generated from business cycles, political crisis, natural disasters or other domestic vulnerabilities, thereby causing a decline in savings.

Chapter 4 investigates the impact of remittances on entrepreneurial environment by employing beta regression model and using panel data including a group of 133 countries over the period 2004-2012. It has long been argued that small, entrepreneurial firms are an important source of innovation, jobs and economic growth for both developed and developing countries. Small businesses, however, face significant legal and regulatory hurdles to be set up. Several case studies suggest that remittances are an important source of investment capital for entrepreneurs in the recipient countries, but no studies have been performed to examine their impact on business regulations and entrepreneurial environment.

We investigate whether remittances enhance the ease of starting a business. The results provide the evidence that remittances can significantly contribute to entrepreneurial performance in the recipient economy via their favorable impact on financial institutions and business regulations. Our findings show that inflows of remittances are conductive to doing business in terms of the 'ease' and 'time' of starting a business. The results suggest that international money transfers generate positive incentives for both suppliers and demanders of financial services.

Finally, Chapter 5 concludes the dissertation by summarizing the major findings and discussing some policy implications. We also highlight a number of potential avenues for future research. 


\section{Chapter 2}

\section{Remittances and Governance: Does}

\section{the Government Free Ride?*}

\section{$2.1 \quad$ Introduction}

The massive increase in cross-border movement of nationals has led to a remarkable growth of global remittances over the last three decades. Remittances now exceed receipts from export earnings and financial inflows of foreign direct investment for many countries (World Bank, 2014). As a key resource of foreign capital in the balance of payments, remittances have outpaced official development assistance and remained more stable than private debt and portfolio equity flows over past several years (see Kapur and McHale, 2005; International Monetary Fund, 2010). Though the effects of global trade and international capital flows on domestic institutions and national policy choices have been studied extensively in the literature (e.g. Quinn, 1997; Rodrik, 1998; Garrett, 2001; Rudra, 2002; Sala-i-Martin and Subramanian, 2003; Rickard, 2012), no such scrutiny has been witnessed with regard to international remittance flows.

${ }^{*}$ I would like to thank my advisor, Prof. Feng Yao, for his guidance throughout this research work. I am thankful to Prof. Stratford Douglas, Prof. Arabinda Basistha, Prof. Andrew Young, and Prof. Philip Michelbach for their constructive comments and suggestions. All remaining errors are mine. 
A range of empirical evidence indicates that the economic impacts of remittances vary across countries and over time (e.g. Glytsos, 1999; Rapoport and Docquier, 2004; Ahmed, 2013). This calls for a nonlinear analysis of the role remittances play across the recipient economies, with particular emphasis on the incentive effects of remittance inflows (Chami et al., 2008). We use the cross-country framework developed by La Porta et al. (1999) and extend the work of Abdih et al. (2012) to study the impact of remittance inflows on the quality of governance across countries and over time. Though we present our baseline results by employing parametric techniques, we primarily focus on nonparametric kernel regressions to analyze the data. These methods allow for uncovering the relevance and linearity of regressors, heterogeneity in partial effects, and endogenous regressors. We use the twostage local polynomial regression estimator developed by Su and Ullah (2008) to handle the endogeneity of remittances. We follow the innovative procedure adopted by Henderson et al. (2013) to select instruments in a nonparametric framework.

From the macroeconomic perspectives on studying the effects of remittances, the primary question arises whether remittances are used to increase consumption (see, e.g., Rempel and Lodbell, 1978; Adams and Page, 2005; Insights, 2006, Acosta et al., 2009) or to increase investment (see, e.g., Taylor and Wyatt, 1996; Ratha, 2003; Giuliano and Ruiz-Arrang, 2009; Aggarwal et al., 2012). These studies have recognized that remittances flows are used either for household consumption or for investment. The pieces of empirical evidence appear to be mixed and controversial. However, many researchers and policymakers claim that remittances contribute significantly to consumption expenditure in the home economies. Whether altruistically motivated or otherwise, an increase in remittances ultimately culminates in a rise in household income and consequently an increase in consumption (Acosta et al., 2009). In many developing countries, the bulk of remittances is spent on consumption (Kapur and McHale 2005). Thus, if remittances are declined, it will directly affect the domestic demand for manufactured goods (Shaffaeddin, 2009). In the context of non-taxable remittances, the share of remittances in private consumption is found to increase (Abdih et al., 2012). Remit- 
tances provide domestic residents insurance against future income shocks resulting in higher private consumption expenditures (see Kapur and Singer, 2006; Orozco, 2004, Chami et al., 2006).

If the inflow of remittances is sufficiently large, it does not only increase the purchasing power of recipient households, but also of the families that are not related to emigration (see Griffin, 1976; Djacjic, 1986). Besides, remittances may induce conspicuous consumption and discourage labor supply (Acosta et al., 2009; Rapoport and Docquier, 2004). When such "pecuniary culture" starts to grow; no class of society, even the most abjectly poor, foregoes all customary conspicuous consumption (Veblen, 1899). The phenomenon of demonstration effect may further raise the consumption expenditure of even non-remittance-recipient households, thereby increasing household consumption in aggregate. Awareness of consumption habits of others tends to inspire emulation of these practices (Duesenberry, 1949). Households in poor countries imitate consumers in rich countries in consumption behavior due to international demonstration that pushes up the propensity to consume in poor countries (Nurkse, 1953). The rapid pace of globalization and migration is a key factor that may intensify the international consumption externalities.

Our findings show that remittance inflows boost household consumption expenditure in the recipient economies relative to government consumption expenditure. As a precursor to our econometric results, looking at the macro level data, we in fact see that a rise in remittances is positively correlated to the rise in household final consumption expenditure relative to the government final consumption expenditure across countries and over time, 2010-2012 (see the upper panels, Figure 2.1). At the same time, for a group of countries that receives a larger size of remittances, this correlation is found to be strong and positive over time, 2002-2012 (see Figure 2.2). These findings are crucial because a large body of literature suggests that household and government consumption are substitutes. The key idea is that the response of economic aggregates to changes in government consumption depends on the relationship between government and private consumption. Public goods substitute while 
merit goods complement private consumption (Fiorito and Kollintzas, 2004). Other scholars have found substitutability between private and public consumption for the US and the UK (Kormendi, 1983; Aschauer, 1985; Bean, 1986; Ahmed, 1986).

Figure 2.1: Remittances (\% of GDP, Remitgdp) and the ratio of household consumption expenditure to government consumption expenditure (Cratio, the upper panels). Consumption expenditures ratio (Cratio) and government control of corruption (Ccorrup, the lower panels), 2010-2012.
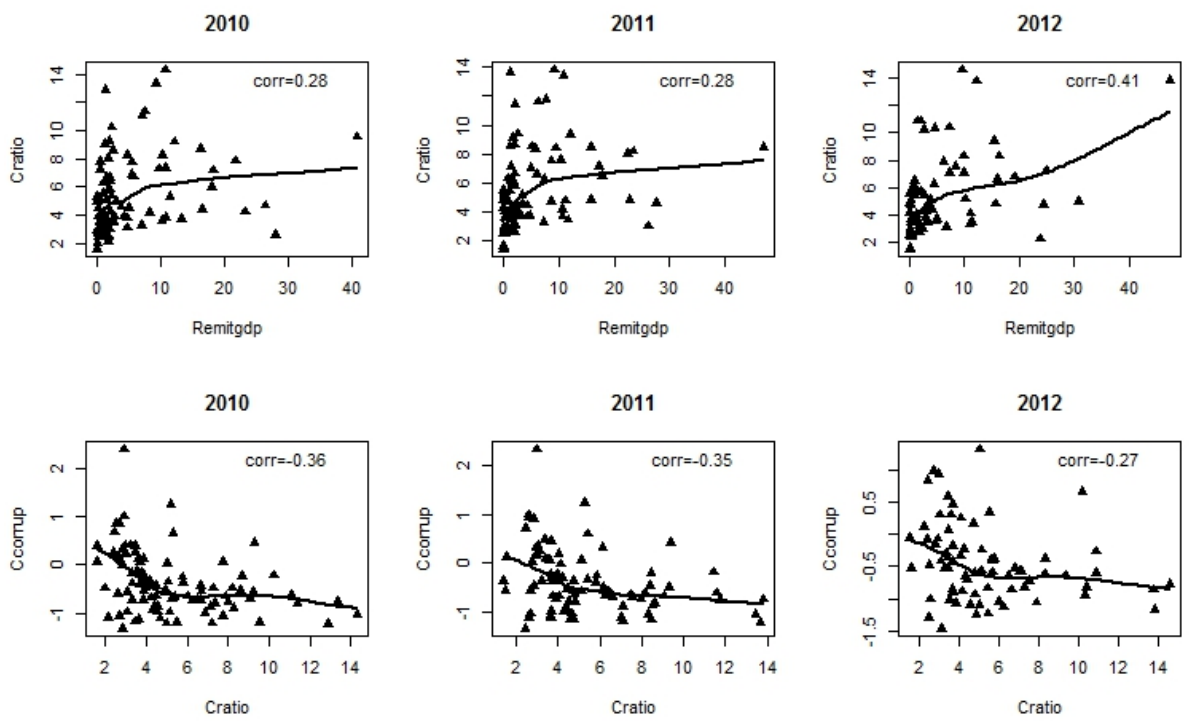

Scatter plots and local polynomial regression (Loess) smoothing. The sample correlation coefficients are also reported.

The substitutability between private and public goods can have important implications. Researchers consider remittances as mostly altruistic in nature and take remittance transfers as gifts, grants or donations. The obvious motivation to remit is simply to care of those left behind: spouses, children, parents, and members of larger kinship and social circles (Rapaport and Docquier, 2004; United Nations Development Program, 2011). However, the government response to such philanthropic supports at national level can shrink the size of public services. Becker and Lindsay (1994) show a dollar-for-dollar crowding-out of public funding by private philanthropic donations for higher education. They get evidence for such government behavior by studying the state-level data for the U. S. economy. They argue that under certain conditions, even democratic governments have some defined tastes over 
the set of public goods produced by the economy so that substitution is a sensible response to changing marginal conditions.

Recent cross-country studies show the evidence that inflow of remittances leads to a decline in the provision of public goods. Remittances reduce the role of insurer of last resort often played by governments in developing countries (Ebeke, 2011). The inflow of remittances does not only reduce government consumption, it also sets governments free from the political conditions; otherwise imposed by organizations such as the International Monetary Fund while borrowing funds or receiving aids (see Kapur and Singer, 2006). Political incentives in less democratic regimes tend to substitute resources from the provision of public goods to the supply of patronage (e.g. corruption) to derive greater utility. For example, governments of non-oil producing Muslim countries are found to optimally choose to reduce their provision of welfare goods as households receive more remittances (Ahmed, 2013). Motivated by narrow interests, the leaders may grant a certain groups the right to appropriate resources from themselves.

Abdih et al.(2012) argue that remittances are curse and cause a decline in the quality of domestic institutions. They develop a model of public goods provision in the presence of non-taxable remittances to show how remittances can lead to increasing share of funds for the government's own purposes diverted from public goods provision, even though remittances do not provide a direct source of revenues for the government. Though they discuss a channel through which remittances could incentivize governments to free ride on resources, they do not specify any channel of influence in their econometric model. They argue that the share of resources for the government's own purposes diverted from public good provision (i.e., corruption) is increasing in remittances relative to the GDP. We take their model up to derive and show that such diversion of resources is positively associated with the ratio of household consumption expenditure to government consumption expenditure (we label this as "consumption expenditures ratio"), which in turn is increasing in the level of remittances relative to the GDP. If the model developed by Abdih et al.(2012) is consistent with the data, 
the consumption expenditures ratio should be one of the potential channels through which remittances affect government corruption. The first contribution of this paper is to provide the evidence for the operation of this channel by specifying consumption expenditures ratio variable explicitly in the econometric model. If remittances do not influence the consumption expenditures ratio, we may not expect the government pursuit to be similar.

Figure 2.2: Remittances (\% of GDP, Remitgdp) and the ratio of household consumption expenditure to government consumption expenditure (Cratio) for a set of countries, 20022012 .
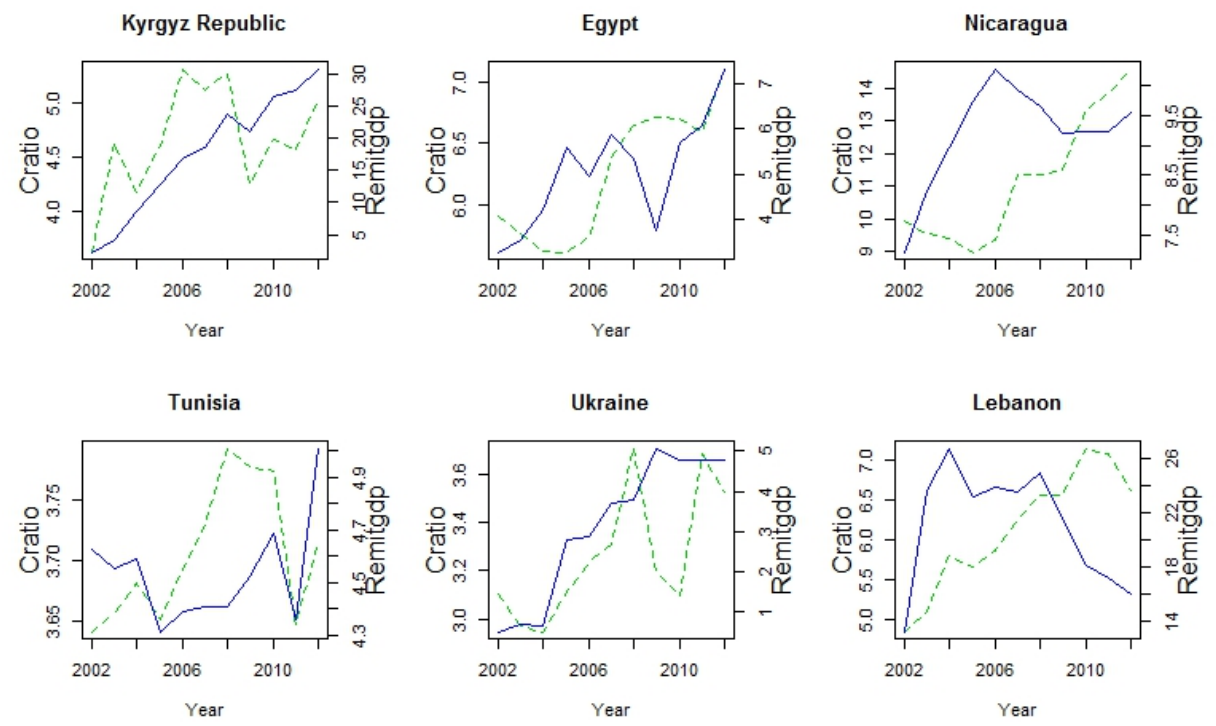

The broken line represents 'Cratio' and the solid line represents 'Remitgdp'.

As such, the lower panel of the scatter plots in Figure 2.1 indicates that there is a negative correlation between consumption expenditures ratio and the index of control of corruption across countries and over time (2010-2012). Also, this correlation is found to be negative and significant over time, 2002-2012 (see Figure 2.3) for the same group of countries receiving higher remittances as we had in figure 2.2. As the control of corruption is inversely related to the level of corruption, the rise in consumption expenditures ratio is positively associated with the rise in the level of corruption. Indeed, our proposition is not only consistent with the aforementioned model but is also in accord with several empirical studies in the literature. As discussed above, researchers show that a rise in remittances is related to a fall in 
Figure 2.3: Consumption expenditures ratio (Cratio) and government corruption (Ccorrup) for the same set of countries as in Figure 2.2, 2002-2012.
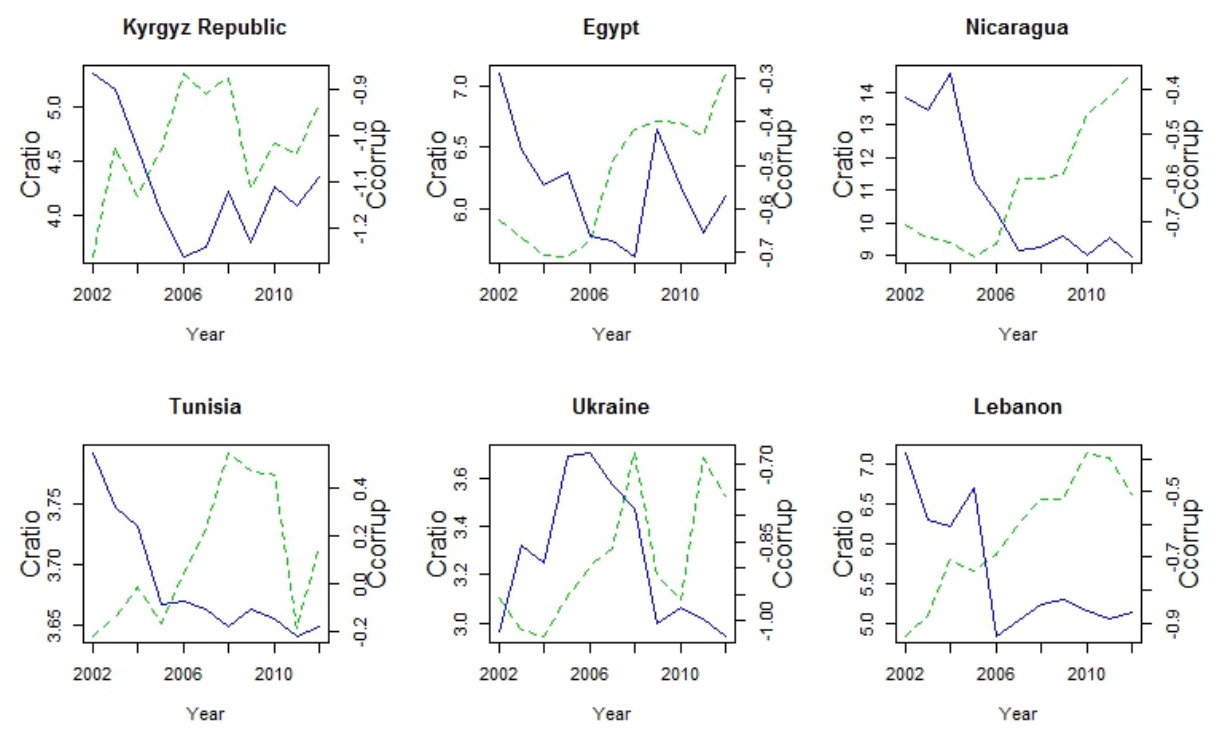

The broken line represents 'Cratio' and the solid line represents 'Ccorrup'.

government consumption expenditure. On the other hand, results from individual country analysis suggest that inflow of remittances is found to boost consumption expenditure in the economy. Such findings implicitly imply that the correlation between the inflow of remittances and the consumption expenditures ratio tends to be positive for the economy as a whole. In other words, households are using an increasing share of remittances to purchase private goods by lowering the quantity of public goods in their baskets, and non-remittancerecipient households are following this pattern as well. The lighter basket of public goods is likely to reduce households' incentives to monitor and hold the government accountable. This may, on the other hand, generate incentives for the government to intervene in the economy.

Akin to the idea of rent-seeking incentives generated by foreign aids (see Bauer, 1972; Bovard, 1986; Alesina and Weder, 2002) and by natural resources such as oil and minerals (see Sala-i-Martin and Subramanian, 2003), some scholars consider the inflow of remittances as a form of economic rent (see Ross 2001; Kapur and McHale, 2005). Kapur and McHale argue that remittances constitute a form of rents at the national level. They discuss that gov- 
ernments may remain reluctant to devise institutional reforms in favor of growing remittance inflows. It is because exporting products requires painstaking effort to build the institutions and infrastructure but exporting people, on the other hand, occurs in most cases by default rather than by design. Sala-i-Martin and Subramanian (2003) show that some windfalls such as revenues from oil and minerals lead to waste, corruption, and deterioration of institutional quality in countries with higher stock of natural resources. State interventions in the form of regulatory policies and fiscal imperatives are often used by the governments to create rents.

Unlike foreign aids or revenues from oil and minerals, governments neither receive remittances directly nor do they tax remittances income (see World Bank, 2006; de Luna Martinez, 2005, Chami et al. 2008). So it is apparent that governments are not benefited from such private familial transfers. However, when the trend and extent of remittance inflows is sufficiently bigger as a share of the country's GDP, the benefits it generates may go beyond recipient households. There are several positive externalities in household consumption in terms of higher standard of living, reduced poverty level, higher human capital via improved health conditions, for instance (see United Nations Development Program, 2011). We assume that most of these benefits generated by increased household consumption have public good qualities, and therefore financing of such consumption via remittances may be subject to government free riding.

Though households must reveal their preference in order to purchase private goods, they do not have such incentive in the case of public goods. There is a distinction between households' demand for public goods and the quantity of public goods they choose in the presence of remittances. Discovering the optimal level of production of public goods is problematic as households can be reluctant to reveal their valuations to the government (see Becker and Lindsay, 1994). On the other hand, if the substitutability of public and private goods holds as discussed earlier, the government will have no incentive to increase the size of public goods even though its marginal social benefits would outweigh the marginal social costs. It is, in fact, the political process that determines the supply of public goods rather 
than the cost-benefit analysis (Hubbard and O'Brien, 2010). The government tendency is to adjust downward the amount of most public goods as it may consider remittances as a "windfall" to households. So the output of public goods is not economically efficient in the presence of remittances. Consequently, the reduced incentives for households to monitor accountability of the government pose a salient question of 'inefficiency' regarding the role of the government. The politicians, however, focus on redistribution rather than efficiency. Political theories hold that policies and institutions are shaped by those in power to stay in power and to transform resources to themselves (La Porta et al., 1999). We therefore conjecture that remittances induce the government itself to free ride on the provision of public goods.

Subsequently, the greater latitude of state interventions is likely to increase the expected benefits for a rational public official from illegitimate transactions with a private partner relative to the likelihood costs or consequences of being caught up in corruption (see Treisman, 2000). Treisman argues that a public official tempts to use the powers of office to create the super-normal profits or "rents" for his partner by intervening in the market by designing certain regulatory or taxation measures to give the partner advantages over rivals in the market. Or the partner may be directly transferred state property under the official's control. In return, the private partner pays the official part of the gain.

To quote Fiorito and Kollingtzas (2004), "the response of economic aggregates to changes in government consumption depends on the relationship between government and private consumption". In effect, the higher the consumption expenditures ratio driven by remittances, the higher is the rent-seeking incentives for the government to intervene in the market to appropriate resources rather than employing them for the provision of public goods and services. The anticipated outcomes are inefficient bureaucracy and the increasing use of public office for personal gains. Our empirical findings strongly support this proposition. We find that the consumption expenditures ratio is positively correlated with the informal payments (i.e., rents) paid to the government officials by the country's firms to get things 
done. The various measures of the quality of governance including the indices of control of corruption, rule of law, and regulatory quality are found to be declining with the rise in consumption expenditures ratio driven by the inflow of remittances.

This chapter is organized as follows. We present our empirical approach in section 2.2 where we also derive key equations for the analysis while being consistent with the model developed by Abdih et al. (2012). A short description of the data and variables is provided in section 2.3. This will follow by a brief outline of parametric results and then the details of nonparametric analysis in section 2.4. Section 2.5 concludes.

\subsection{Empirical methodology}

The local constant kernel estimator for a nonparametric panel specification that treats individual (country) identifier and time as additional categorical explanatory variables is now common practice in applied research (e.g., Henderson et al., 2013; Czekaj and Henningsen, 2013). In such specification, time can also be considered as a continuous variable (Li and Racine, 2007). The bandwidths for the explanatory variables in a mix of continuous and categorical variables are selected via generalized product kernel functions (see Racine and Li, 2004).

Let us consider the following nonparametric panel data regression model (see Racine, 2008):

$$
y_{i t}=g\left(x_{i t}\right)+u_{i t} ; \quad i=1,2, \cdots, N ; \quad t=1,2, \cdots, T
$$

Where $y_{i t}$ is the observed regressand, $g($.$) is the unknown but smooth regression function,$ $x_{i t}=\left(x_{i t, 1}, \ldots, x_{i t, q}\right)$ is a vector of regressors of dimension $q, E\left(u_{i t} / x_{i t, 1}, \ldots, x_{i t, q}\right)=0, i$ represents individual unit, and $t$ represents time.

The unknown function $g($.$) in equation (2.1) can be estimated using the local constant$ kernel estimator as mentioned above. This estimation strategy is preferable to traditional parametric panel methods in several respects. The traditional approach allows heterogenity 
across countries and time by employing numerous country and year dummies in the specification resulting in the considerable loss of degrees of freedom. By including individual country identifier as a categorical variable and time as either a categorical or a continuous variable, the kernel approach does not only allow to control country fixed-effects and timespecific effects but also allow them to interact among the regressors. The kernel estimator does not suffer from the loss of observations because there is no data transformation or first-differencing. The inclusion of time as a continuous variable in the nonparametric specification is similar to one of the traditional approach that allows time variation by specifying a linear or quadratic time trend in the model.

The defining characteristic of this nonparametric approach is that the individual and time effects are non-additive and non-separable. This means that the level of the dependent variable 'intercept' and also the marginal effects of the explanatory variables on the dependent variable 'slopes' may differ between time periods and between individuals and the time effects may depend on the individual, while the individual effects may vary over time. Hence, the kernel method does not imply any restrictions on the models. Furthermore, the bandwidths of the explanatory variables can be selected using data-driven cross-validation methods. Thus, the overall shape of the relationship between the dependent variable and the regressors, the individual, and time is entirely determined by the data (Czekaj and Henningsen, 2013).

In this paper, we use the nonparametric specification (2.1) with time as a continuous variable and estimate it using the local constant estimator. However, we exclude the country identifier. This model choice is crucial for our analysis due to two reasons. First, the specification (2.1) allows parameter heterogeneity across country and time as mentioned in the previous paragraph. The structure of relationship between variables are determined nonparametrically by kernel methods that allow interaction among variables. Second, most of the explanatory variables in our model are time-invariant exogenous variables. Inclusion of exogenous explanatory variables in the model even make a pooled model appropriate for 
the analysis because they are not correlated to the country-specific component of the model error (see Ashley, 2012). As the included time-invariant exogenous variables take account of several country-specific characteristics, the omitted variable bias due to unobserved factors/attributes of the country is assumed to be negligible. So, it is less important to model other portion of variation in the expected value of $y_{i t}$ across countries which is not explained by the across-country variations in the explanatory variables. For example, if ethnic fractionalization of a country affects government corruption in 2002, it will also affect corruption in 2012. But once the ethnic fractionalization is taken into account, no further manipulation regarding its effect (or such fixed effects) is required in the model.

We employ several country-level fixed attributes in the specification such as legal origins, religious affiliation of the population, ethnic fractionalization, and geographical features including the country's latitude and topography. These variables are considered as exogenous to the quality of governance (La Porta et al., 1999). Had we chosen the fixed-effects model instead, the expected impacts of these time-invariant explanatory variables on the left-hand side variable were likely to be wiped-out. Thus, we argue that once the country-level heterogeneity is taken into account in terms of the included regressors (that are unique to individual country and capture individual heterogeneity), controlling for additional fixed-effects causes redundancy in our model. For comparison with the nonparametric analysis, however, we use OLS estimation of parametric panel versions of nonparametric model (2.1).

We employ the theoretical cross-country framework developed by La Porta et al.(1999)and extend it to panel studies as suggested by Ahdih et al.(2012) but will apply the nonparametric regression tools to identify the relevance and linearity of explanatory variables to emphasize the role of the data for selecting the appropriate models. Under our modeling procedure, the unknown function $g($.$) in model (2.1) can be interpreted as the conditional$ mean of the response variable $y$ given the vector of regressors $x$. One of the commonly employed nonparametric estimators is the local-constant (Nadaraya-Watson) kernel estimator of the conditional mean function $g($.$) which can be written as$ 


$$
\hat{g}(x)=\frac{\sum_{i=1}^{n} y_{i} \prod_{s=1}^{q} K\left(\frac{x_{s i}-x_{s}}{h_{s}}\right)}{\sum_{i=1}^{n} \prod_{s=1}^{q} K\left(\frac{x_{s i}-x_{s}}{h_{s}}\right)},
$$

Where, $\prod_{s=1}^{q} K\left(\frac{x_{s i}-x_{s}}{h_{s}}\right)$ is the product kernel and $h_{s}$ is the smoothing parameter (bandwidth) for a particular regressor $x_{s}$ (see Henderson et al., 2013). Similar to the minimization of sum of squared residuals in Ordinary Least Squares (OLS), the estimator (2.2) is the solution of the minimization (of the integrated mean squared error (IMSE) of the estimator) problem that uses a 'constant'to approximate the conditional mean function $g($.$) (or y$ ) in the neighborhood of regressors $x$ (see Li and Racine, 2007). In other words, the estimator (2.2) is the locally weighted average of $y$ by considering those values of $y$ which are within a small area in terms of the values taken by the explanatory variables, $x$. We can think this estimator as the smooth moving average of $y$. One could instead use a local linear kernel estimator to estimate $g($.$) to address the bias arising from asymmetry of kernel weights at$ the boundaries of the domain of regressors. However, given the specific regression function of slowly evolving institutional characteristics, we ignore this boundary issue and use the local constant estimator (2.2).

An important feature of the kernel regression is that it allows us to identify whether an explanatory variable is relevant to a model. It also indicates whether the relevant variable enters the model linearly. For exploratory purpose, we employ the fully data-driven cross-validation methods of bandwidths selection with time as a categorical variable. After selecting the explanatory variables to be included in the model, we use the 'rule-of-thumb' method for bandwidths selection for the regressors in estimation. This method of bandwidths selection is also employed by $\mathrm{Su}$ and Ullah (2008) to conduct their estimator's asymptotic properties. As our regression function is supposed to be flat that represents slowly evolving institutional characteristics conditional on several country-level fixed attributes, we assume all regressors enter to the regression function symmetrically. This is the major reason behind 
our choice of the rule-of-thumb method (see Li and Racine, 2007). We use the second order Gaussian kernel for continuous variables and Li and Racine kernel for ordered and unordered categorical variables in all estimation purposes.

Our choice of the kernel regression method is primarily based on its benefits of studying the heterogeneity in partial effects and handling of the endogenous regressors. A detail explanation of this approach in an empirical setting can be found in Henderson et al.(2013). As remittances may be potentially endogenous with the quality of governance, we use the two-stage local polynomial regression estimator developed by Su and Ullah (2008) to handle the endogeneity of remittances. We adopt the innovative procedure to select instruments in a nonparametric framework proposed by Henderson et al.(2013).

In the remaining of this section, we present our key propositions mathematically and consistently within the model developed by Abdih et al.(2012). Their key argument is that the resources diverted by the government for its own purposes is increasing in the level of remittances relative to GDP. We show below that the resource diversion is positively associated with the ratio of household consumption to government consumption expenditures and the ratio itself is increasing in the level of remittances relative to GDP.

Starting from equation (10) in Abdih et al., (see Abdih et al., 2012)

$$
\frac{\overline{s^{*}}}{\overline{g^{*}}}=\frac{\beta y+\beta R}{(t-\beta) y-\beta R}
$$

Where $\frac{\bar{s}^{*}}{\bar{g}^{*}}$ is the rate of resource diversion by the government (optimal level of resources diverted by the government as a ratio of total government spending), $\beta$ represents a measure of incentives for the government to divert resources to its own consumption such that $\beta>$ $0, R$ stands for the size of remittance inflows, and $y$ is the measure of the GDP. Now, substituting $R$ in (2.3) from the budget constraint equation in Abdhi et al.,

$$
\overline{\bar{s}^{*}}=\frac{\beta y+\beta R}{(t-\beta) y-\beta R}=\frac{\beta y+\beta\left(c+g^{*}-y+t y\right)}{(t-\beta) y-\beta R}
$$


Where $c$ is household consumption of private goods and $g^{*}$ is the households ${ }^{\prime}$ optimal demand for public goods. By simplification,

$$
\frac{\overline{s^{*}}}{\overline{g^{*}}}=\frac{\beta\left(c+g^{*}+t y\right)}{\overline{g^{*}}}=\frac{\beta\left(c+g^{*}\right)+\beta t y}{\overline{g^{*}}}=\frac{\beta t y}{\overline{g^{*}}}+\frac{\beta\left(c+g^{*}\right)}{\overline{g^{*}}}
$$

In equation $(2.5)$, the quantity $\frac{\left(c+g^{*}\right)}{g^{*}}$ or equivalently $\frac{\frac{c+g^{*}}{y}}{\frac{g^{*}}{y}}$ represents the ratio of optimal household consumption expenditure (\% of GDP) to the optimal government provision of public goods (\% of GDP) in an economy where remittances are non-taxable (see Ahdih et al., 2012). By approximating the government provision of public goods by the government consumption expenditure (\% of GDP), we get from (2.5):

$$
\frac{\overline{s^{*}}}{\overline{g^{*}}}=\frac{\beta t}{\overline{g^{*}} / y}+\beta * \text { Consumption expenditures ratio (Cratio) } ; \beta>0
$$

The "consumption expenditures ratio" stands for the ratio of household consumption expenditure (\% of GDP) to government consumption expenditure (\% of GDP). Expressing for the consumption expenditures ratio, using (2.3) and (2.6),

$$
\begin{aligned}
& \text { Cratio }=\frac{1}{\beta}\left[\frac{s^{*}}{\overline{g^{*}}}-\frac{\beta t y}{\overline{g^{*}}}\right]=\frac{1}{\beta}\left[\frac{\beta y+\beta R}{(t-\beta) y-\beta R)}-\frac{\beta t y}{(t-\beta) y-\beta R}\right] \\
& =\frac{1}{\beta}\left[\frac{\beta y+\beta R-\beta t y}{(t-\beta) y-\beta R}\right]=\frac{1}{\beta}\left[\frac{\beta(y+R-t y)}{(t-\beta) y-\beta R}\right]=\left[\frac{(y+R-t y)}{(t-\beta) y-\beta R}\right]
\end{aligned}
$$

Multiplying and dividing the last expression by $y$,

$$
\text { Cratio }=\left[\frac{(1-t+(R / y)}{(t-\beta)-\beta(R / y)}\right]
$$

Differentiating with respect to $R / y$,

$$
\frac{\partial(\text { Cratio })}{\partial(R / y)}=\frac{\partial}{\partial(R / y)}\left[\frac{1-t+(R / y)}{(t-\beta)-\beta(R / y)}\right]
$$


Applying the quotient rule in (2.7),

$$
=\frac{\frac{\partial[1-t+(R / y)]}{\partial(R / y)}[(t-\beta)-\beta(R / y)]-\frac{\partial[(t-\beta)-\beta(R / y)]}{\partial(R / y)}[1-t+(R / y)]}{[(t-\beta)-\beta(R / y)]^{2}}
$$

By simplification,

$$
\frac{\partial(\text { Cratio })}{\partial(R / y)}=\frac{t(1-\beta)}{[(t-\beta)-\beta(R / y)]^{2}}>0
$$

Now let us consider equations (2.6) and (2.8) together. Abdih et al. (2012) argue that resource diversion by the government is increasing in the level of remittances relative to GDP. We have shown that the resource diversion is positively associated with the ratio of household consumption expenditure to government consumption expenditure (i.e., consumption expenditures ratio) at their optimal levels (\% of GDP) as shown by equation (2.6), and the consumption expenditures ratio itself is increasing in the level of remittances relative to GDP as shown by equation (2.8). The main contribution of this paper is to test these propositions empirically in the following sections by including both variables, i.e., remittances and consumption expenditures ratio in the model specification. As these two variables are potentially correlated, if the consumption expenditures ratio is excluded from the model (as in Abdih et al., 2012), the coefficient estimates will suffer from the omitted variable bias or endogeneity. We argue that it is the consumption expenditures ratio channel through which the inflow of remittances drives the government to be a free rider. We show our results to be very robust and stable across estimation techniques.

\subsection{Data and variables}

Our data comes from three major sources: the World Bank databases (Worldwide Governance Indicators (WGI) and World Development Indicators (WDI)), the Heritage Foundation, and the Center for International Development at Harvard University (CID). Our primary measure of the quality of governance is the "control of corruption index" (Ccorrup) 
from WGI database. Other measures of governance quality include rule of Law (rulelaw), regulatory quality(regqua) (from WGI), and freedom from corruption index (frcorrup) from the Heritage Foundation database. These indicators from WGI are based on 32 individual data sources produced by a variety of survey institutes, think tanks, non-governmental organizations, international organizations, and private sector firms (WGI, the World Bank). We also use the informal payments to public officials (\% of firms) as one of our measures of government performance. This approximates the government's rent-seeking behavior, defined as the percentage of firms expected to make informal payments to public officials to "get things done" with regard to customs, taxes, licenses, regulations, services, and the like.

We proxy the household consumption by household final consumption expenditure (\% of GDP) and the government consumption by the general government final consumption expenditure (\% of GDP). The main variable of interest in our analysis is the ratio household final consumption expenditure (\% of GDP) to the general government final consumption expenditure (\% of GDP), and we label this as "consumption expenditures ratio" (Cratio). We include both consumption expenditures ratio and remittances (\% of GDP) in the econometric model. Remittances(Remitgdp) is defined as the sum of worker's remittances, compensation of employees, and migrant's transfers in the balance of payments. These variables come from WDI. Other explanatory variables from WDI include GDP per capita (constant 2005 US\$, Lgdppc); trade (sum of exports and imports (\% of GDP), Open); energy depletion (\% of GNI, Energy) defined as the ratio of the value of the stock of energy resources to the remaining reserve lifetime that covers coal, crude oil, and natural gas.

The remaining control variables proxy for the country level fixed characteristics such as legal origin variables (defined in terms of binary variables for British common law, Socialist/communist laws, and French, Germany, and Scandinavian commercial codes); religious affiliation of the population (defined as the percentage of the population of each country that belonged to Catholic, Muslim, Protestant, and other religious denominations (as per 1980 data)); and geographical variables including country's latitude (absolute value of the 
latitude of the country, scaled to take values between 0 and 1), and coastal area (defined as $\%$ of total land of a country within $100 \mathrm{~km}$ of coast, Lnd100km). These control variables are collected from the Center for International Development at Harvard University (CID). Also, the control for ethnic fractionalization (Ethnic, expressed as an index variable that measures "ethnicity" as a combination of racial and linguistic characteristics, see Alesina et al., 2003) comes from the official website of University of California Anderson School of Management. A summary statistics of all the variables used in the analysis can be found in Table 10 (see Appendix).

The period of analysis covers 2002 - 2012. Our cross-country time-series dataset forms an unbalanced panel consisting of 106 countries based on the availability of data that excludes the Group of Seven (G7) countries, Western European OECD countries, and Australia. The reason is that these countries are structurally different from the rest of the world regarding governance quality and their responses to remittances. The total number of country-year observations in the dataset is 1025 . The dataset is available from the author upon request.

\subsection{Empirical findings}

\subsubsection{Parametric estimates}

Table 2.1-2.4 present our parametric panel estimates for the model of the quality of governance. The index of control of corruption is the main dependent variable. However, we analyze the regression models with other measures of governance throughout the analysis. Following La Porta et al. (1999), we employ the cross-country framework with historical, political and social determinants of government performance as our control variables in the specification. We include our variables of interest: remittances and the consumption expenditures ratio in most of our model specifications.

We summarize our findings from the linear parametric models in Tables 1-4 (see Appendix). Table 2.1 presents the estimates for several versions of panel models. We pooled 
the data and include time trend in the first column. As most of our explanatory variables are time-invariant, the fixed-effects model is not an appropriate option for our analysis. In other words, it does not allow to study the impacts of time-invariant regressors on the dependent variable because the process of data transformation removes these variables from the models. As a complement to the fixed-effects model, we estimate between-effects panel models for some specifications. Between effects models are similar to the cross sectional analysis but the difference is that it averages the values for each regressor over the entire time periods and run the OLS to these averaged values. So we need to discard time variation in betweeneffects estimation. When we include both remittances and consumption expenditures ratio in the model, the coefficient on consumption expenditures ratio is negative and statistically significant. However, the coefficient on remittances is negative but not significant. This finding is consistent when we run random effects models in columns 4 and 5 with no time effects. However, when we include time-effects, the coefficient on remittances turn to be insignificant in column 6 . As random effects models allow the country specific-effects to be random, it also allows cross country variations to make influence on the dependent variables. In other words, the heterogeneity across countries may be the cause of the variation in the left-hand side variable and the random effects model takes this variation into account. As most of the regressors including historical, political and religious explantory variables are exogenous (see La Porta et al., 1999), these variables are not supposed to be correlated with the country-specific effects and the use of random effects model appears suitable in our analysis.

On the other hand, if the explanatory variables are correlated with the country-specific effects, random effects model will not provide consistent estimates. To take this into account, and to address the endogeneity of remittances on the regression of government corruption, we employ the Hausman-Taylor estimation. Under certain conditions, this provides the consistent estimation of even the time-invariant explanatory variables. The seventh and eighth columns of Table 2.1 presents the estimates from the Hausman-Taylor strategy. The 
results from this estimation show that the coefficient with the consumption expenditures ratio is negative and statistically significant at $1 \%$ level, but the coefficient on the remittances is not significant, though it retains negative sign.

The adverse impacts of the consumption expenditures ratio on government performance is further supported by the estimation results with other measures of governance as reported in Table 2.2. We use the rule of law, regulatory quality, and the informal payments to government officials (\% of firms) for rent-seeking purposes as our other measures of the quality of governance. Whereas the consumption ratio negatively affects first of these two measures, the coefficient with the third measure comes with positive sing and statistically significant magnitude (see the seventh column in Table 2.2). This implies that the rise in the consumption expenditures ratio as a result of remittance inflows increases the arbitrariness in the public administration and the bureaucracy. Our findings from the linear parametric models show that the rise in remittances and the resulting increase in the consumption expenditures ratio lead to the deterioration of the country's economic, social, and political institutions. We also assess the robustness of above findings by regressing corruption on 3-year average of explanatory variables in Table 2.3. We find that our previous results still hold, and with impressively significant coefficient estimates.

Before completing the outline of our results from this section, it is important to note that the correlation between the inflow of remittances and the consumption expenditures ratio is positive and statistically significant (see Table 2.4). The coefficient estimates on remittances is positive and statistically significant in the model with household final consumption expenditure, the case is not similar with the model where government final consumption is the dependent variable. These findings provide us strong supports for our hypothesis that the inflow of remittances rises household consumption relative to the government consumption in the recipient economies. While we mentioned our findings with grater emphasis on just two variables in this section, we see that the estimates with most of our control variables are consistent with the general findings in the literature. We will investigate these issues further 
below with the nonparametric econometric analyses.

\subsubsection{Nonparametric estimates}

We explore several benefits of nonparametric techniques to study the impacts of remittances on the quality of governance, and on corruption in particular. Using the fully data-driven cross-validation method of bandwidths selection, we examine whether an explanatory variable is relevant in the specification; and whether it enters the model linearly. We focus on the relationship between remittances and consumption expenditures ratio and their impacts on the dependent variable. We also present the estimates for each included regressor from our nonparametric models. These estimates shed light on the underlying partial effects of the particular regressor on the dependent variable across countries and over time. We address the bias and inconsistency problems arising from the endogeneity of remittances by employing instrumental variables strategy within the nonparametric framework.

\section{Irrelevant regressors}

The traditional approach in regression analysis is to specify a linear model with a known functional form and to use ordinary least squares to estimate the unknown parameters. Usually, a researcher uses his/her knowledge of economic theory whether or not to include a particular variable in the model specification. As the true regression functional form is rarely known in practice, the parameter estimates are likely to be inconsistent. The nonparametric kernel regression is an alternative for such deficiencies in the traditional methods.

Using cross-validation methods for bandwidths, we can detect whether a variable is relevant in the regression model. If so, it is considered to be a useful predictor of the left-hand side variable. Hall et al. (2007) show that with local constant estimator with least square cross-validation method, when the bandwidths on any regressor reaches its upper bound, the regressor is essentially 'smoothed out'in the sense that it does not play a role to explain any of the variation in the conditional mean of the dependent variable. As the upper bound turns 
to be at infinity, when the bandwidth exceeds a few standard deviations of the regressor, the variable is considered irrelevant in practice (Henderson et al., 2013). For our analysis, we consider the upper bound for a continuous variable as two times the standard deviation of the variable. For a categorical variable, the lower and upper bounds with Li and Racine kernel are 0 and 1.

We include all the explanatory variables in the regression specification as in the parametric models with religion variables. However, if we use legal variables in this exploration, the resulting bandwidths are equivalent. Table 2.5 presents the bandwidths from least squares cross-validation methods. The columns denoted by 'UB'represent the upper bound for the bandwidths for each regressor. The first three columns deal with control of corruption as the dependent variable. In this regression, the bandwidths from local constant (LC) estimator for both consumption expenditures ratio and remittances are smaller than their upper bounds. This suggests that both of them are relevant predictors of corruption. This supports our hypothesis that consumption expenditures ratio appears to be a potential channel of influence for government corruption.

The bandwidths selected via local constant estimator for GDP per capita, ethnolinguistic fractionalization, and Muslim religion are also less than their upper bounds. So they are relevant in the prediction of government corruption as suggested by economic theories. The bandwidth for economic openness variable is far greater than its upper bound implying that it is not a potential regressor in the corruption equation. This provides a support for La Porta et al. (1999) who did not specify economic openness variable in their framework. However, this idea is against many empirical studies that consider economic openness as a key factor to influence government behavior (e.g., Garrett, 2001; Ricard, 2012). However, the bandwidths for a country's latitude and Catholic religion indicate that they are not relevant in the model. In fact, our data set excludes many developed countries with higher scales of latitude. The implication is that a link between latitude and government performance is weakened in the sample. This may be the reason why Abdih et al. (2012) excluded latitude 
variable from the list of explanatory variables. A country's stock of natural resources, on the other hand, is not showing relevance in government corruption as the local constant bandwidth for energy variable is very large in comparison to its upper bound. This signals against the notion of natural resource course literature that larger stock of natural resources deteriorates governance and hinders growth (see Sala-i-Martin and Subramanian, 2003). A few number of oil-rich countries in our data sample may explain why this finding may arise due to sample selection bias.

The fifth column represents bandwidths for regressors for the model in which rule of law is the dependent variable. The bandwidth for consumption expenditures ratio is smaller than its upper bound, thereby making it a relevant predictor of a country's quality of contract enforcement, property rights, the police, and the courts. However, the local constant bandwidth for remittances is far greater than its upper bound. This non-relevance of remittances in the rule of law regression implies that remittance variable is not a factor responsible for any variation in the country's rule of law indicator. This is a strong support for our proposition that remittances itself does not affect government performance. It is the consumption expenditures ratio that possibly connects the influence of remittances inflows to the quality of governance across countries. In rule and law regression, Catholic religion appears to be a relevant variable. The bandwidths for the remaining variables are consistent with the bandwidths in second column.

Unlike bandwidths from local constant estimator for corruption and rule of law regressions, the bandwidth for consumption expenditures ratio is larger than its upper bound in regulatory quality equation. However, the size is not sufficiently bigger in comparison to the case of remittances in the rule of law equation. If we considered three times the standard deviation of a regressor for the upper bounds instead of two times, consumption expenditures ratio would appear as a relevant variable. As there are no such firm rules in these exploratory works, we will employ formal regression analyses to examine our propositions in the following sections. 


\section{Remittances and Cratio: Bandwidth results}

We claim that an increase in the inflow of remittances leads to a rise in the consumption expenditures ratio (Cratio). The bandwidths selected via local constant least squares crossvalidation method says that if the bandwidth for a regressor is smaller than its upper bound, the regressor is relevant; in the sense that it is a potential candidate for explaining the variation in the left-hand side variable. So it is important to look at the bandwidth for remittance variable in the regression of consumption expenditures ratio. The bandwidths for this regression are shown in the final two columns of Table 2.5. Under the same set of regressors, we see that the local constant estimator produces the bandwidth for the remittances which is much smaller than its upper bound. What this says is that remittances is a key factor to predict the variation in consumption expenditures ratio and so there is a potential correlation between these two variables. We must therefore specify not only remittances in a model for

the quality of governance, but we also need to include the consumption expenditures ratio to avoid misspecification of our econometric model, and to reduce the problems due to omitted variable bias. We will proceed in the direction of these bandwidth results.

\section{Identifying linearity}

The bandwidths for each regressor estimated via local linear kernel estimator using least squares cross-validation methods are presented in the third, sixth, and the ninth column of Table 2.5. These bandwidths show a fairly common picture of how each of our regressors enters the regression model. As the bandwidths for all regressors are relatively smaller than their upper bounds, their relationship with the dependent variable is a nonlinear process. We therefore can not assume a linear model for our empirical analysis. We conduct the Hasio et al. (2007) test for the regression models represented by Table 2.5 to examine whether a linear parametric model is a possibility, but reject the null of correct linear speicification at $1 \%$ level of significance. Thus, a linear model can not capture the true data generating process. The better performance of the nonparametric models lies on the fact that they allow 
for interactions among the explanatory variables. Uncovering the underlying heterogeneity in partial effects is the defining characteristic of the nonparametric kernel regression.

\section{Partial effects}

The study of bandwidths provided us indication whether our explanatory variables are relevant to the model. One or more of the regressors were not relevant in one regression model but they appeared relevant in another regression model(s) of the quality of governance. So, based on the modeling framework of La Porta et al. (1999) and inputs from the related literature, we include all the regressors in the nonparametric estimation as in the parametric models presented earlier. This also facilitates the comparison of the nonparametric estimates with their parametric counterparts.

Table 2.6 presents the local constant quartile coefficient estimates from our nonparametric models of the quality of governance. The estimates correspond to the $25 \mathrm{th}, 50 \mathrm{th}$, and 75 th percentiles (denoted by Q1, Q2, and Q3) of the estimated parameter distribution. These partial effect estimates for each variable are obtained by holding all other regressors at their median values. The first three columns show quartile estimates for the regression model where control of corruption is the dependent variable. These nonparametric results reveal some crucial features of our data. First, the estimates vary substantially from one quartile value to another quartile value for all regressors. This can be observed from the graphical plots of the estimated coefficients for some of the regressors in Figure 2.4. The implication of this finding goes against the homogeneity assumption or parameter stability in parametric linear models. The estimated kernel estimates simply indicate that heterogeneity among countries is a challenging issue and can not be avoided in studying the partial effects of a particular explanatory variable on the dependent variable. A careful reader will notice that the fit in nonparametric estimation is almost twice of that of parametric models. This further justifies the results from the Hasio et al. (2007) model specification test we conducted earlier. 
Figure 2.4: Kernel density plots of estimates using local constant estimator for the regression model of corruption. Note: 'Cratio' stands for the consumption expenditures ratio while some plots are excluded.
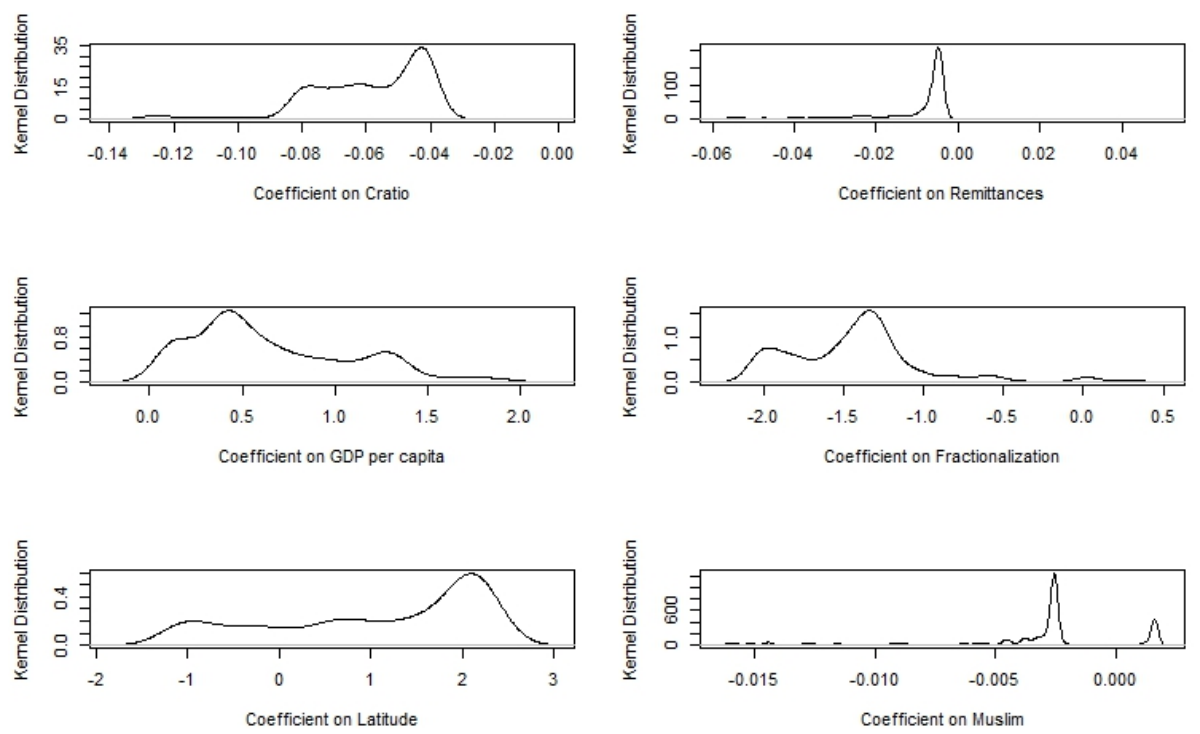

Second, the qualitative results from the nonparametric estimation do not change from their parametric counterparts presented in Table 2.1 and Table 2.2. In most cases, the estimates do not only have the same sign, but they also have equal magnitudes. The partial effect of the logarithm of real GDP is positive and significant at all quartiles. The partial effects of ethnolinguistic fractionalization and Muslim religion on government performance are negative and significant as found in the development economics literature (see La Porta et al. 1999, Alesina et al., 2003). Catholic denomination has similar negative impacts; but the partial effects of latitude are positive and significant on corruption. Again, this unexpected result may indicate the sample selection bias in our data set as we excluded most of the developed world from our data sample. The estimates with stock of natural resources come with negative sign but is not significant as was the case in parametric results. As we discussed, this biased outcome may arise due to the inclusion of only a few number of oil-rich countries in our sample. On the other hand, the economic openness appear to have a positive and significant impact on corruption. Though open economies are often found to abide by international norms and principles of good governance, excessively liberalized economies in 
the early stages of economic development may suffer from bureaucratic malfunctions.

Third, our main explanatory variables: consumption expenditures ratio and remittances come with negative coefficient estimates. For the consumption expenditures ratio, the partial effects are negative and strongly significant (see also Figure 2.4). Though the estimates for remittances are negative, they are insignificant. These results do not only confirm our findings from earlier analyses, but they also imply a potential mechanism about how the impacts of remittances occur on government performance. Remittances clearly show a negative association with government corruption, but the channel of influence is not as direct as in the econometric model of Abdih et al. (2012). The adverse impacts run through the substitutability relationship between household and government consumption expenditures. It is only when households use remittances to buy increasingly larger amount of private goods relative to public goods and services in their consumption, the government enters into the system via reduction of public goods provision. Government does so because there are several positive externalities in households' consumption due to increase in their disposable (remittance) income. The motive of government is to substitute public goods for remittances and to appropriate economic resources for its own political objectives as we discussed earlier. The macroeconomic consequences of the government intervention in the economy are the fragile bureaucracy, inefficient output of public goods and services, and deteriorating economic and political institutions.

In Table 2.6, we also perform robustness checks for our results from the control of corruption regression with other measures of the quality of governance. The other columns in Table 2.6 present the estimates when rule of law and regulatory quality are dependent variables respectively. The partial effect estimates from these models show it clearly that our claims in the preceding paragraph are not without justifications. The results provide strong supports for the government free riding over the provision of public goods and services. The partial effects of consumption expenditures ratio on both indicators of the quality of governance, viz., rule of law and regulatory quality are negative and statistically signif- 
icant. Again, though remittances affect these variables negatively, the coefficient estimates are not statistically significant as in the previous results. The partial estimates for all other regressors on these two indicators of governance are consistent with those from the regression model of corruption.

\section{Level effects}

It is crucial to examine how the partial impacts of remittances and consumption expenditures ratio vary across their levels. Our findings show that a rise in remittances causes a rise in consumption expenditures ratio. As the increase in consumption expenditures ratio adversely affects the quality of governance, we would like to explore how this impact changes with the rise in the levels of these variables across countries.

To carry out this analysis, we split the estimated partial estimates for consumption expenditures ratio and remittances into four disjoint groups by the data samples of these variables. The partial effect estimates are divided by the quartiles of remittances and consumption expenditures ratio. We then report the $25 \mathrm{th}, 50 \mathrm{th}$, and 75 th percentiles of the distribution of each group of estimates to see the level impacts of these variables on government performance. We present the results of this aspect of analysis in Table 2.7. In the first regression with control of corruption as a dependent variable, the median partial effects of consumption expenditures ratio rises when the level of consumption ratio increases from its lower quartile until it reaches to its third quartile value. The partial effects then decline. This finding is consistent with other measures of the government performance presented in Table 2.7. The implication is that when the rise in remittances leads to higher private consumption, the government characterizes the increase in housholds' (remittance) income as a windfall. Over the course of time, the government intensifies the downward adjustment of the size of provision of public goods and services to substitute them for remittances. 


\section{Remittances and Cratio: Nonparametric estimates}

In previous section, we presented our baseline results showing the relationship between remittances, household final consumption expenditure, and government final consumption expenditure using linear models. We found that remittances significantly explain the variation in both household final consumption expenditure and consumption expenditure ratio (Cratio). The coefficient estimates with remittances in both of these cases were found to be positive and highly significant. However, the relationship between remittances and government final consumption expenditure was not explicit. To examine these relationship further, we estimate the same set of models as in Table 2.4 but now employing kernel methods. The nonparametric estimates from this analysis are presented in Table 2.8 and Table 2.9. The quartile estimates with remittances in the model of household consumption are all positive with a large variation in the size of coefficients (see columns 2-4, Table 2.8). Importantly, the estimates at the range of upper quartile (Q3) and beyond are found to be statistically significant. The percentile estimates at this specific range of coefficient distribution are reported with corresponding bootstrap standard errors in the upper panel of Table 2.9. On the other hand, the quartile estimates with remittances are all negative in the model of government consumption which are presented in columns 5-7 in Table 2.8. In this model, most of the estimates at the range of lower quartile (Q1) and below are statistically significant. The percentile estimates at this range are presented with corresponding bootstrap standard errors in the central panel of Table 7a. Furthermore, in the model of consumption expenditures ratio, the quartile estimates with remittances are all positive (see columns 8-10, Table 2.8), whereas the estimates with the upper quartile and beyond are found to be statistically significant (see lower panel, Table 2.9.). These nonparametric coefficient estimates are depicted along with bootstrap standard errors in Table 2.10 , once we split the estimates by the quartiles data values on remittances. The estimates at the lower quartile, Q1, are significant irrespective of the group. Note that estimates in all groups and ranges are negative.

Instead of considering the single global parameter estimate from the strictly restricted 
linear parametric model as in Table 2.4, if we look at the heterogeneity in the partial effects of remittances on government consumption expenditure in Tables $2.8-2.10$, most of the nonparametric estimates bear negative sign with varying partial impacts. So we conclude this section with the claim that a rise in remittances is associated with a decline in the size of government consumption expenditures across countries, thereby revealing a case of governmental free-riding on the provision of public goods and services in the presence of remittances.

\section{Instrumental variables estimation}

In this subsection, we consider the regression model with government corruption as the dependent variable. We allow remittances to be endogenous. To isolate the potential causality from remittances to corruption, we introduce an instrumental variable, namely, the coastal area defined as the $\%$ of total land of a country within $100 \mathrm{~km}$ of coast. This variable have been commonly employed in empirical works in development economics literature. We examine the relevance and validity of our instrument via local constant cross-validation method of bandwidth selection. Table 2.11 presents the resulting bandwidths for the included regressors.

We follow Henderson et al.(2013) approach for selecting instruments in a nonparametric framework. From the second column in Table 2.11, we see that the coastal area variable is smoothed out of the regression because its bandwidth from local constant is far greater than its upper bound, and so it is not a relevant predictor of the left-hand-side variable, i.e., government corruption. However, this variable is found to be relevant in the regression of remittances as shown in the fourth column of Table 2.11 because the bandwidth for the coastal variable is much less than the upper bound. We argue in the corruption equation that the coastal variable does not influence government corruption but is highly correlated with remittances which we believe is potentially endogenous. This variable has been used as an instrument for remittances in some cross-sectional studies (see Abdih et al., 2012). From 
our analysis, we consider the coastal area of a country to be a relevant and valid instrument for remittances. As we have a single endogenous regressor and one instrument, our new model is just identified.

We apply Su and Ullah (2008) two-stage local polynomial estimator for estimating our new model. The Su and Ullah estimator provides a consistent estimation of nonparametric simultaneous equations models under certain conditions. There are three consecutive stages for applying $\mathrm{Su}$ and Ullah (2008) estimator to data. In the first stage, we regress the endogenous variable, that is, remittances on its instrument (coastal area) and all other exogenous explanatory variables. The GDP per capita could be endogenous with governance, so we have replaced it by initial GDP per capita (logarithm of GDP per capita for 2002). We employ the local constant estimator and use the rule-of-thumb method for bandwidths for the regressors. We extract the residual from the estimated model to be used in the second stage. In the second stage, as we have only continuous variables in the model, we again employ the local constant estimator to regress our response variable, control of corruption, on this residual, the endogenous variable, and other relevant explanatory variables. Finally, we employ the marginal integration technique to derive the marginal effects of our variables of interest on government corruption. The local constant nonparametric estimates for the consumption expenditures ratio from the third stage are presented in Table 2.12.

The results from the instrumental variables estimation are very close to the estimated partial effects obtained from the nonparametric estimation of the model as presented in Table 2.6. The estimates as presented in Table 2.12, retain the sign as in nonparametric partial effects and the magnitudes are also equivalent. This result provides a very convincing support for our hypothesis that the inflow of remittances adversely affects the quality of governance through the consumption expenditures ratio channel. The findings from our nonparametric instrumental variables estimation are very consistent to all of our previous results. 


\subsection{Concluding remarks}

In this essay, we have investigated the potential causality between inflow of remittances and the quality of governance across countries and over time. Our findings show that remittances do not directly affect government performance. This is because remittances represent private familial transfers and are not directly taxed. However, when the extent and growth of remittance inflows is sufficiently large in the share of the country's GDP, it can potentially affect the incentives faced by households and the government in remittance-receiving economies. Our results indicate that rise in remittances are associated with an increasing demand for private goods but a decreasing share of public goods in household consumption. Concerning government motivation, we find a significant negative association between remittances and government consumption expenditure. This implies that remittances induce the government to substitute the provision of public goods for remittances. Our empirical study, therefore, provide evidence of governmental free-riding on public goods provision in the presence of remittances. The econometric analysis suggests that substitution of resources occurs in a nonlinear fashion across countries; and leads to higher government corruption, deterioration of rule and law, and inferior regulatory quality; thereby causing a loss in public welfare.

The findings imply that public-private partnership can be an important mechanism to avoid potential misallocation of public resources in the presence of remittances. Such collaborative efforts can significantly contribute to productive investment, both in private and public sectors. Recently, international organizations, financial agencies, and many governments have increased their focus on how to channelize flows of remittances through formal financial institutions. The lessons from this analysis are expected to contribute to these global efforts to redirect remittances inflows from current uses toward empowering households and increasing their access to financial products and services. The use of remittances to this end can avoid the consequences of governmental free-riding on the provision of public goods and services, thereby materializing potential benefits from remittances by leveraging them for economic growth and development. 


\subsection{Bibliography}

1. Abdih, Y., Chami, R., Dagher, J., and Montiel, P. (2012), Remittances and Institutions: Are Remittances a Curse? World Development, Vol. 40, No. 4, pp. 657-666.

2. Adams R. H., and Page, J. (2005), Do International Migration and Remittances Reduce Poverty in Developing Countries? World Development, Vol. 33, No. 10, pp. 1645-1669.

3. Aggarwal, R., Demirguc-Kunt, A., and Peria, M. S. M. (2006), Do Workers' Remittances Promote Financial Development?, Journal of Development Economics, Vol. 96, pp. $255-264$.

4. Ahmed, S. (1986), Temporary and permanent government spending in an open economy, Journal of Monetary Economics 17, 197224.

5. Ahmed, F. Z. (2013), Remittances Deteriorates Governance, The Review of Economics and Statistics, Vol. 95, No. 4, pp. 1166-1182.

6. Alesian, A. (2003), Fractionalization, Journal of Economic Growth, 8, 155-194.

7. Aschauer, D. A. (1985), Fiscal policy and aggregate demand, American Economic Review $75(1), 117127$.

8. Ashley, R. A. (2012), Fundamentals of Applied Econometrics, Wiley, John Wiley and Sons, Inc.

9. Bean, C. R. (1986), The estimation of surprise models and the surprise consumption function, Review of Economic Studies 53, 497516.

10. Becker, E., and Lindsay, C. M. (1994), Does the Government Free Ride?, Journal of Law and Economics, Vol. 37, No. 1, pp. 277-296.

11. Chami, R., Barajas, A., Cosimano, T., Fullenkamp, C., Gapen, M., and Montiel, P. (2008), Macroeconomic Consequences of Remittances, International Monetary Fund, Washington DC. 
12. Czekaj, T., and Henningsen, A. (2013), Panel Data Specifications in Nonparametric Kernel Regression: An Application to Production Functions, IFRO Working Paper, Department of Food and Resource Economics,University of Copenhagen.

13. DJajic, S. (1986), International Migration, Remittances and Welfare in a Dependent Economy, Journal of Development Economics 21, 229-234. North-Holland.

14. Duesenberry, J., S. (1949), Income, Saving and the Theory of Consumption Behavior, Cambridge, Mass.: Harvard University Press.

15. Ebeke, C. H. (2011), Remittances, Countercyclicality, Openness and Government Size, International Monetary Fund, Washington DC.

16. Feinberg, R. M., and Hustead, T. A. (2011), Do States Free Ride in Antitrust Enforcement?, American University.

17. Fe-Rodriguez, E. (2009), Adaptive Instrumental Variable Estimation of Heteroskedastic Error Component Models, School of Social Sciences, The University of Manchester.

18. Fiorito, R., and Kollintzas, T. (2004), Public goods, merit goods, and the relationship between private and government consumption, European Economic Review, 48, 1367-1398.

19. Fomby T., and Hill, R. C. (2000), Applying Kernel and Nonparametric Estimation to Economic Topics, Jai press Inc. Stamford, Connecticut.

20. Garrett, G. (2001), Globalization and Government Spending around the World, Studies in Comparative International Development, Vol. 35, No. 4, pp. 3-29.

21. Giuliano, P. and Ruiz-Arranz, M. (2005), Remittances, Financial Development, and Growth, IMF Working Paper, WP/05/234, Research Department.

22. Glytsos, N. P. (2002), Dynamic Effects of Migrant Remittances on Growth: An Econometric Model with an Application to Mediterranean Countries, Centre of Planning and Economic Research, No 74 . 
23. Grabel, I. (2008), The Political Economy of Remittances: What Do We Know? What Do We Need to Know?, Working Paper Series, No 184, Political Economy Research Institute, University of Massachusetts Amherst.

24. Hardle, W., Muller, M., Sperlich, S., and Werwatz, A. (2004), Nonparametric and Semiparametric Models, Springer.

25. Hausman J. A., and Taylor, W. E. (1981), Panel Data and Unobservable Individual Effects, Econometrica, Vol. 49, No. 6, 1377-1398.

26. Henderson, D. J., Papageorgiou, C., and Parmeter, C. F. (2013), Who benefits from financial development? New methods, new evidence, European Economic Review, 63, 47-67.

27. Henderson D. J., and Maasoumi, E. (2012), Searching for Rehabilitation in Nonparametric Regression Models with Exogenous Treatment Assignment, IZA DP No. 6874.

28. Hsing, C. C. (1958), Capital Formation in Underdeveloped Countries, University of Ottawa, Ottawa, Canada.

29. Hubbard, R. G., and O'Brian A. P. (2010), Microeconomics, Third Edition.

30. Kapur, D., and McHale, J. (2005), Give Us Your Best and Brightest: The Global Hunt for Talent and Its Impact on the Developing World, Center for Global Development, Ideas to Action, Independent Research for Global Prosperity.

31. Kapur, D., and Singer, D. A., (2006), Remittances, Government Spending, and the Global Economy, Annual Meeting of International Studies Association, San Diego, CA, March 22-25.

32. Kormendi, R.C. (1983), Government debt, government spending and private sector behavior, American Economic Review 73 (5), 9941010.

33. La Porta, R., Lopez-de-Silanes, F., Shleifer, A., and Vishny, R. (1999), The Quality of Government, Journal of Law, Economics, and Organization, Vol. 15, Issue 1, pp. 222-279. 
34. Li, Q., and Racine, J. S. (2004), Cross-Validated Local Linear Nonparametric Regression, Statistica Sinica 14, 485-512.

35. Li, Q., and Racine, J. S. (2007), Nonparametric Econometrics, Theory and Practice, Princeton University Press, Princeton and Oxford.

36. Liu P., and Sun G. (2005), International Demonstration Effects and Domestic Division of Labour: A Simple Model, Discussion Papers, Department of Economics, Monash University, Clayton, Vic. 3800, Australia.

37. Marcel, M. (2012), Budgeting for Fiscal Space and Government Performance Beyond the Great Recession, OECD Better Policies for Better Lives.

38. McCormic, B., and Wahba, J. (2000). Overseas Employment and Remittances to a Dual Economy, The Economic Journal, Vol. 110, No. 463, pp. 509-534.

39. Migration and Remittances, Factbook 2011, The World Bank.

40. Nurkse, R. (1953) Problems of Capital Formation in Underdeveloped Countries, Blackwell, Oxford.

41. Parmeter, C. F. (2013), A Quick Guide on Nonparametric Density and Regression Estimation in $R$.

42. Pulpanova, L. V. (2013), Understanding Government Consumption, University of Economics, Prague, Czech Republic.

43. Quinn, D. (1997), The Correlates of Change in International Financial Regulation, American Political Science Review, Vol. 91, No. 3.

44. Racine, J. S., and Hayfield, T. (2013), The np Package: The Nonparametric Kernel Smoothing Methods for Mixed Data Types.

45. Racine, J. S. (2014), Package np FAQ.

46. Racine, J. S. (2008), Nonparametric and Semiparametric Methods in $R$. 
47. Rao, B. B., and Hassan, G. M. (2011), A panel data analysis of the growth effects of remittances, Economic Modelling, 28, 701-709.

48. Ratha, D. (2013), The Impacts of Remittances on Economic Growth and Poverty Reduction, Migration Policy Institute, Policy Brief, No. 8, Migration and Development, the World Bank.

49. Ratha, D. (2003), Leveraging Remittances for Development, Federal Reserve Bank of Dallas.

50. Rapoport, H., and Docquier, F. (2004), The Economics of Migrant's Remittances, Stanford Center for International Development, Working Paper No. 236.

51. Rempel, H., and Lobdell, R. A. (1977), The Role of Urabn-Rural Remittances in Rural Development, University of Manitoba.

52. Rickard, S. J. (2012), Welfare versus Subsidies: Governmental Spending Decisions in an Era of Globalization, The Journal of Politics, vol. 74, No. 4, pp. 1171-1183.

53. Rodrik, D. (1998), Why Do More Open Economies Have Bigger Governments?, Journal of Political Economy.

54. Ross, M. L. (2001), Does Oil Hinder Democracy?, World Politics 53, 325-61.

55. Rudra, N. (2002), Globalization and the Decline of the Welfare State in Less-Developed Countries, International Organization, Vol. 56, Issue 02, pp 411-445.

56. Sala-i-Martin X., and Subramanian A. (2003), Addressing the Natural Resource Curse: An Illustration from Nigeria, Working Paper 9804, National Bureau of Economic Research. 57. Segura-Ubiergo, A., and Kaufman, R. R. (2001), Globalization, Domestic Politics, and Social Spending in Latin America: A Time-Series Cross-Section Analysis, 1973-97, World Politics, Vol. 53, No. 4, pp. 553-587.

58. Su L., and Ullah A. (2008), Local polynomial estimation of nonparametric simultaneous equations models, Journal of Econometrics, 144, 193-218. 
59. Tanner, M. (2012), The American Welfare State: How We Spend Nearly $\$ 1$ Trillion a Year Fighting Poverty- and Fail?, Policy Analysis, CATO Institute.

60. Tibshirani R., and Wasserman, L. (2014), Nonparametric Regression, Statistical Machine Learning.

61. Treisman D. (2000), The causes of corruption: a cross-national study, Journal of Public Economics 76, 399-457.

62. Towards Sustaining Millennium Development Goals (MDG), Chapter 4 (Remittances), The United Nations Development Program (UNDP).

63. Veblen, T. (1899), The Theory of the Leisure Class, NY, Macmillan, pp. 64-70.

64. Wooldridge, J. M. (2003), Introductory Econometrics: A Modern Approach, Second Edition, Thomson, South-Western.

65. Wooldridge, J. M. (2010), Econometric Analysis of Cross Section and Panel Data, Second Edition, The MIT Press, Cambridge, Massachusetts, London.

66. Yang, D., (2011), Migrant Remittancs, Journal of Economic Perspectives, Volume 25, Number 3, Pages 129-152. 
Table 2.2: Remittances and the quality of governance: parametric panel estimates.

\begin{tabular}{|c|c|c|c|c|c|c|c|}
\hline \multirow[b]{3}{*}{ Variable } & \multicolumn{7}{|c|}{ Dependent variables: measures of the quality of governance ${ }^{1}$} \\
\hline & \multicolumn{2}{|c|}{ rule of law } & \multicolumn{2}{|c|}{ regulatory quality } & \multicolumn{2}{|c|}{ freedom from corruption } & \multirow{2}{*}{$\frac{\text { informal pay }}{\text { Between }}$} \\
\hline & Random & Haus-Taylor & Random & Haus-Taylor & Random & Haus-Taylor & \\
\hline Cratio & $\begin{array}{r}-0.01^{* *} \\
(0.00437)\end{array}$ & $\begin{array}{r}-0.009^{* *} \\
(0.00432)\end{array}$ & $\begin{array}{r}-0.015^{* * *} \\
(0.0048)\end{array}$ & $\begin{array}{l}-0.015^{* * *} \\
(0.00474)\end{array}$ & $\begin{array}{l}-0.499^{* * *} \\
(0.16192)\end{array}$ & $\begin{array}{l}-0.441^{* * *} \\
(0.16813)\end{array}$ & $\begin{array}{r}2.426^{* * *} \\
(0.85198)\end{array}$ \\
\hline Remitgdp & $\begin{array}{l}-0.0033^{* *} \\
(0.00146)\end{array}$ & $\begin{array}{r}-0.003^{*} \\
(0.00145)\end{array}$ & $\begin{array}{r}0.0009 \\
(0.00160)\end{array}$ & $\begin{array}{r}-0.00131 \\
(0.00159)\end{array}$ & $\begin{array}{r}0.0297 \\
(0.55227)\end{array}$ & $\begin{array}{r}0.1042^{*} \\
(0.05782)\end{array}$ & $\begin{array}{r}0.1202 \\
(0.25931)\end{array}$ \\
\hline Lgdppc & $\begin{array}{c}0.667^{* * *} \\
(0.7461)\end{array}$ & $\begin{array}{r}0.702^{* * *} \\
(0.8561)\end{array}$ & $\begin{array}{r}0.792^{* * *} \\
(0.08269)\end{array}$ & $\begin{array}{r}0.856^{* * *} \\
(0.09644)\end{array}$ & $\begin{array}{r}13.375^{* * *} \\
(1.7245)\end{array}$ & $\begin{array}{r}11.433^{* * *} \\
(2.5706)\end{array}$ & $\begin{array}{r}-3.324 \\
(6.2217)\end{array}$ \\
\hline Energy & $\begin{array}{l}-0.008^{* * *} \\
(0.00157)\end{array}$ & $\begin{array}{l}-0.007^{* * *} \\
(0.00158)\end{array}$ & $\begin{array}{r}-0.0024 \\
(0.00172)\end{array}$ & $\begin{array}{r}-0.0013 \\
(0.00174)\end{array}$ & $\begin{array}{l}-0.197^{* * *} \\
(0.05111)\end{array}$ & $\begin{array}{l}-0.170^{* * *} \\
(0.05888)\end{array}$ & $\begin{array}{r}0.888^{* *} \\
(0.32748)\end{array}$ \\
\hline Open & $\begin{array}{r}-0.0005 \\
(0.00042)\end{array}$ & $\begin{array}{r}-0.0003 \\
(0.00042)\end{array}$ & $\begin{array}{r}0.0003 \\
(0.00046)\end{array}$ & $\begin{array}{r}0.0002 \\
(0.0005)\end{array}$ & $\begin{array}{r}0.037^{* *} \\
(0.01509)\end{array}$ & $\begin{array}{r}0.031^{*} \\
(0.0161)\end{array}$ & $\begin{array}{r}0.0294) \\
(0.06599)\end{array}$ \\
\hline Ethnic & $\begin{array}{r}-0.2810 \\
(0.20554)\end{array}$ & $\begin{array}{r}-0.2246 \\
(0.25667)\end{array}$ & $\begin{array}{r}-0.3177 \\
(0.22886)\end{array}$ & $\begin{array}{r}-0.2631 \\
(0.29522)\end{array}$ & $\begin{array}{l}-7.517^{*} \\
(4.0522)\end{array}$ & $\begin{array}{r}-6.7215 \\
(6.7028)\end{array}$ & $\begin{array}{r}7.8634 \\
(12.0593)\end{array}$ \\
\hline Lat_abs & $\begin{array}{r}0.822^{* *} \\
(0.39263)\end{array}$ & $\begin{array}{r}0.7611 \\
(0.48632)\end{array}$ & $\begin{array}{r}0.0735 \\
(0.4370)\end{array}$ & $\begin{array}{r}-0.0059 \\
(0.55847)\end{array}$ & $\begin{array}{r}8.9922 \\
(7.8277)\end{array}$ & $\begin{array}{r}13.757 \\
(12.842)\end{array}$ & $\begin{array}{r}5.5907 \\
(21.3309)\end{array}$ \\
\hline Legor_UK & $\begin{array}{r}0.411^{* * *} \\
(0.10508)\end{array}$ & $\begin{array}{r}0.422^{* * *} \\
(0.13128)\end{array}$ & $\begin{array}{r}0.337^{* * *} \\
(0.11702)\end{array}$ & $\begin{array}{r}0.337^{* *} \\
(0.1507)\end{array}$ & $\begin{array}{l}5.453^{* * *} \\
(2.0548)\end{array}$ & $\begin{array}{r}5.474 \\
(3.41408)\end{array}$ & $\begin{array}{r}29.155^{* * *} \\
(8.63689)\end{array}$ \\
\hline Legor_SO & $\begin{array}{r}-0.2226 \\
(0.14197)\end{array}$ & $\begin{array}{r}-0.1982 \\
(0.17644)\end{array}$ & $\begin{array}{r}0.0915 \\
(0.15805)\end{array}$ & $\begin{array}{r}0.1144 \\
(0.20288)\end{array}$ & $\begin{array}{l}-6.980^{* *} \\
(2.8156)\end{array}$ & $\begin{array}{r}-7.492 \\
(4.62017)\end{array}$ & $\begin{array}{r}19.874^{* * *} \\
(7.11221)\end{array}$ \\
\hline Legor_GE & $\begin{array}{r}0.3216 \\
(0.44379)\end{array}$ & $\begin{array}{r}0.3382 \\
(0.55235)\end{array}$ & $\begin{array}{r}0.1261 \\
(0.49423)\end{array}$ & $\begin{array}{r}(0.1275) \\
(0.63566)\end{array}$ & $\begin{array}{r}-5.676 \\
(8.61901)\end{array}$ & $\begin{array}{r}-3.4921 \\
(14.3406)\end{array}$ & \\
\hline Intercept & $\begin{array}{r}-2.557^{* *} \\
(0.28289)\end{array}$ & $\begin{array}{l}-2.776^{* * *} \\
(0.34263)\end{array}$ & $\begin{array}{l}-2.666^{* * *} \\
(0.31387)\end{array}$ & $\begin{array}{l}-2.935^{* * *} \\
(0.38845)\end{array}$ & $\begin{array}{r}-8.4973 \\
(6.49953)\end{array}$ & $\begin{array}{r}-3.7995 \\
(9.96184)\end{array}$ & $\begin{array}{r}1.2976 \\
(26.9876)\end{array}$ \\
\hline Time & Yes & Yes & Yes & Yes & Yes & Yes & No \\
\hline Observations & 1025 & 1025 & 1025 & 1025 & 1025 & 1025 & 42 \\
\hline$R^{2}$ & 0.503 & $\mathrm{~N} / \mathrm{A}^{2}$ & 0.445 & $\mathrm{~N} / \mathrm{A}$ & 0.514 & $\mathrm{~N} / \mathrm{A}$ & 0.636 \\
\hline
\end{tabular}


Table 2.3: Parametric estimates with 3-year average of explanatory variables. ${ }^{\dagger}$

\begin{tabular}{|c|c|c|c|c|}
\hline & \multicolumn{4}{|c|}{ Dependent variable: freedom from corruption index } \\
\hline Variable & Pooled OLS & Random-effects & Random-effects & Haus-Taylor \\
\hline Cratio & $\begin{array}{r}-0.547^{* *} \\
(0.223)\end{array}$ & $\begin{array}{l}-0.531^{*} \\
(0.282)\end{array}$ & $\begin{array}{r}-0.535^{*} \\
(0.0802)\end{array}$ & $\begin{array}{r}-0.573^{*} \\
(0.3201)\end{array}$ \\
\hline Remitgdp & $\begin{array}{r}-0.296^{* * *} \\
(0.077)\end{array}$ & $\begin{array}{r}-0.0339 \\
(0.0898)\end{array}$ & $\begin{array}{r}-0.072 \\
(0.0901)\end{array}$ & $\begin{array}{r}0.0981 \\
(0.0990)\end{array}$ \\
\hline Lgdppc & $\begin{array}{r}12.454^{* * *} \\
(1.359)\end{array}$ & $\begin{array}{r}14.088^{* * *} \\
(2.107)\end{array}$ & $\begin{array}{r}13.583^{* * *} \\
(2.121)\end{array}$ & $\begin{array}{r}11.017^{* * *} \\
(3.753)\end{array}$ \\
\hline Energy & $\begin{array}{r}-0.323^{* * *} \\
(0.054)\end{array}$ & $\begin{array}{r}-0.268^{* * *} \\
(0.0759)\end{array}$ & $\begin{array}{r}-0.289^{* * *} \\
(0.075)\end{array}$ & $\begin{array}{r}-0.2688^{* * *} \\
(0.1001)\end{array}$ \\
\hline Ethnic & $\begin{array}{r}-6.684^{* *} \\
(2.823)\end{array}$ & $\begin{array}{l}-8.164^{*} \\
(4.895)\end{array}$ & $\begin{array}{l}-8.495^{*} \\
(4.709)\end{array}$ & $\begin{array}{r}-10.023 \\
(8.536)\end{array}$ \\
\hline Legor_UK & $\begin{array}{r}5.347^{* * *} \\
(1.338)\end{array}$ & $\begin{array}{l}5.389^{* *} \\
(2.400)\end{array}$ & $\begin{array}{l}5.2057 \\
(2.304)\end{array}$ & $\begin{array}{r}4.7804 \\
(3.9103)\end{array}$ \\
\hline Legor_SO & $\begin{array}{r}-8.371^{* * *} \\
(1.902)\end{array}$ & $\begin{array}{r}-7.478^{* *} \\
(3.345)\end{array}$ & $\begin{array}{l}-7.739 \\
(3.222)\end{array}$ & $\begin{array}{l}-8.453 \\
(5.406)\end{array}$ \\
\hline Legor_GE & $\begin{array}{r}-5.134 \\
(5.150)\end{array}$ & $\begin{array}{r}-5.235 \\
(9.859)\end{array}$ & $\begin{array}{r}-5.434 \\
(9.444)\end{array}$ & $\begin{array}{r}-3.483 \\
(16.232)\end{array}$ \\
\hline Time & No & No & Yes & Yes \\
\hline $\mathrm{R}^{2}$ & 0.518 & 0.513 & 0.521 & $\mathrm{~N} / \mathrm{A}$ \\
\hline Observations & 350 & 350 & 350 & 350 \\
\hline
\end{tabular}


Table 2.4: Remittances, household and government consumption expenditures, and consumption expenditures ratio: ${ }^{1}$ parametric panel estimates.

\begin{tabular}{|c|c|c|c|c|c|c|}
\hline \multirow[b]{2}{*}{ Variable } & \multicolumn{2}{|c|}{ household consumption } & \multicolumn{2}{|c|}{ government consumption } & \multicolumn{2}{|c|}{ consumption exp. ratio } \\
\hline & Random & Haus-Taylor & Random & Haus-Taylor & Random & Haus-Taylor \\
\hline Remitgdp & $\begin{array}{r}0.620^{* * *} \\
(0.04477)\end{array}$ & $\begin{array}{r}0.565^{* * *} \\
(0.04534)\end{array}$ & $\begin{array}{r}0.029^{*} \\
(0.01757)\end{array}$ & $\begin{array}{r}0.0265 \\
(0.01735)\end{array}$ & $\begin{array}{r}0.025^{* *} \\
(0.01057)\end{array}$ & $\begin{array}{r}0.023^{* *} \\
(0.01085)\end{array}$ \\
\hline Lgdppc & $\begin{array}{r}-16.392^{* * *} \\
(1.59638)\end{array}$ & $\begin{array}{r}-23.635^{* * *} \\
(2.62983)\end{array}$ & $\begin{array}{r}0.3198 \\
(0.81623)\end{array}$ & $\begin{array}{c}-2.2015^{*} \\
(1.12305)\end{array}$ & $\begin{array}{l}-2.459^{* * *} \\
(0.42674)\end{array}$ & $\begin{array}{r}-2.573^{* *} \\
(0.49018)\end{array}$ \\
\hline Energy & $\begin{array}{l}-0.517^{* * *} \\
(0.04387)\end{array}$ & $\begin{array}{l}-0.477^{* * *} \\
(0.04895)\end{array}$ & $\begin{array}{r}-0.041^{* *} \\
(0.01850)\end{array}$ & $\begin{array}{r}-0.042^{* *} \\
(0.01908)\end{array}$ & $\begin{array}{l}-0.029^{* * *} \\
(0.01076)\end{array}$ & $\begin{array}{r}-0.028^{* *} \\
(0.01105)\end{array}$ \\
\hline Open & $\begin{array}{r}0.0046 \\
(0.01251)\end{array}$ & $\begin{array}{r}0.0018 \\
(0.01296)\end{array}$ & $\begin{array}{l}-0.018^{* * *} \\
(0.00503)\end{array}$ & $\begin{array}{r}-0.0236^{* * *} \\
(0.00500)\end{array}$ & $\begin{array}{l}-0.009^{* * *} \\
(0.00299)\end{array}$ & $\begin{array}{r}0.010^{* * *} \\
(0.00301)\end{array}$ \\
\hline Ethnic & $\begin{array}{r}2.9513 \\
(3.96412)\end{array}$ & $\begin{array}{r}-1.4835 \\
(7.75313)\end{array}$ & $\begin{array}{r}0.8279 \\
(2.18832)\end{array}$ & $\begin{array}{l}-0.1395 \\
3.60909\end{array}$ & $\begin{array}{r}-2.304^{* *} \\
(1.09356)\end{array}$ & $\begin{array}{r}-2.712^{* *} \\
(1.28600)\end{array}$ \\
\hline Lat_abs & $\begin{array}{r}6.6912 \\
(7.63739)\end{array}$ & $\begin{array}{r}19.358 \\
(14.5766)\end{array}$ & $\begin{array}{r}12.978^{* * *} \\
(4.19109)\end{array}$ & $\begin{array}{l}17.857^{* * *} \\
(6.74764)\end{array}$ & $\begin{array}{r}-5.02374^{* *} \\
(2.10221)\end{array}$ & $\begin{array}{r}-5.251^{* *} \\
(2.43811)\end{array}$ \\
\hline Legor_UK & $\begin{array}{c}-3.431^{*} \\
(2.02044)\end{array}$ & $\begin{array}{r}-4.5350 \\
(3.93164)\end{array}$ & $\begin{array}{r}2.257^{*} \\
(1.11846)\end{array}$ & $\begin{array}{r}2.2334 \\
(1.83401)\end{array}$ & $\begin{array}{r}-0.7476 \\
(0.55812)\end{array}$ & $\begin{array}{r}-0.8065 \\
(0.64968)\end{array}$ \\
\hline Legor_SO & $\begin{array}{r}-2.7751 \\
(2.75611)\end{array}$ & $\begin{array}{r}-5.6494 \\
(5.2864)\end{array}$ & $\begin{array}{r}-1.3196 \\
(1.51489)\end{array}$ & $\begin{array}{r}-2.0506 \\
(2.45846)\end{array}$ & $\begin{array}{r}0.6126 \\
(0.75869)\end{array}$ & $\begin{array}{r}0.5508 \\
(0.87901)\end{array}$ \\
\hline Legor_GE & $\begin{array}{r}-2.2179 \\
(8.50950)\end{array}$ & $\begin{array}{r}0.0639 \\
(16.5379)\end{array}$ & $\begin{array}{r}-0.7452 \\
(4.72324)\end{array}$ & $\begin{array}{r}0.4229 \\
(7.7167)\end{array}$ & $\begin{array}{r}-0.35214 \\
(2.35407)\end{array}$ & $\begin{array}{l}-0.4374 \\
2.72968\end{array}$ \\
\hline Intercept & $\begin{array}{r}(119.9610)^{* * *} \\
(5.73194)\end{array}$ & $\begin{array}{r}144.676^{* * *} \\
(10.4751)\end{array}$ & $\begin{array}{r}10.629^{* * *} \\
(3.00107)\end{array}$ & $\begin{array}{l}19.331^{* * *} \\
(4.61226)\end{array}$ & $\begin{array}{r}15.603^{* * *} \\
(1.54674)\end{array}$ & $\begin{array}{r}16.166^{* * *} \\
(1.88361)\end{array}$ \\
\hline Time & Yes & Yes & Yes & Yes & Yes & Yes \\
\hline Observations & 1025 & 1025 & 1025 & 1025 & 1025 & 1025 \\
\hline$R^{2}$ & 0.668 & $\mathrm{~N} / \mathrm{A}^{2}$ & 0.107 & $\mathrm{~N} / \mathrm{A}$ & 0.309 & $\mathrm{~N} / \mathrm{A}$ \\
\hline
\end{tabular}

Cluster-robust standard errors in parentheses.

*** $p<0.01,{ }^{* *} p<0.05,{ }^{*} p<0.10$.

${ }^{1}$ It is the ratio of household final consumption expenditure (\% of GDP) to the government final consumption expenditure (\% of GDP).

${ }^{2} R^{2}$ is not available from the Hausman-Taylor estimation. The Wald-test statistic is significant at $1 \%$ level in all cases. 
Table 2.5: Bandwidths for regressors in the model for the quality of governance. UB is the upper bound for a regressor. LC and LL represent local constant and local linear estimators respectively.

\begin{tabular}{|c|c|c|c|c|c|c|c|c|c|c|c|c|}
\hline \multirow[b]{2}{*}{ Variable } & \multicolumn{3}{|c|}{ control of corrup $^{1}$} & \multicolumn{3}{|c|}{ rule of law } & \multicolumn{3}{|c|}{ regulatory quality } & \multicolumn{3}{|c|}{${\text { consumption } \text { ratio }^{2}}^{2}$} \\
\hline & UB & $\mathrm{LC}$ & $\overline{\mathrm{LL}}$ & UB & $\mathrm{LC}$ & $\overline{\mathrm{LL}}$ & UB & $\mathrm{LC}$ & $\overline{\mathrm{LL}}$ & UB & $\mathrm{LC}$ & LL \\
\hline Cratio & 5.99 & 3.581111 & 0.8292202 & 5.99 & 0.6252993 & 0.8292202 & 5.99 & 9.833136 & 0.8292202 & & & \\
\hline Remitgdp & 15.585 & 8.155771 & 0.7172383 & 15.585 & 73451773 & 2.571313 & 15.585 & 4.766323 & 1.410357 & 15.585 & 7.963851 & 1.234704 \\
\hline Lgdppc & 1.103 & 0.2065935 & 0.1680556 & 1.103 & 0.03052719 & 0.1680556 & 1.103 & 0.1320732 & 0.1682575 & 1.103 & 0.03191172 & 0.161775 \\
\hline Energy & 21.15 & 347667175 & 0.5696509 & 21.15 & 24853974 & 0.5264752 & 21.15 & 13.08047 & 0.4833702 & 21.15 & 5.468488 & 0.486225 \\
\hline Open & 70.28 & 48105520 & 13.36632 & 70.28 & 19250594 & 9.65027 & 70.28 & 106944381 & 9.649285 & 70.28 & 106179042 & 9.289601 \\
\hline Ethnic & 0.47 & 0.0004119 & 0.071137 & 0.47 & 0.036509 & 0.097029 & 0.47 & 0.019563 & 0.0712012 & 0.47 & 0.003765 & 0.086439 \\
\hline Lat_abs & 0.352 & 8389.516 & 0.053557 & 0.352 & 0.001202 & 0.0294164 & 0.352 & 0.000878 & 0.053567 & 0.352 & 0.00663 & 0.0515683 \\
\hline Catholic & 71.453 & 12963124 & 5.329379 & 71.453 & 3.280204 & 5.466731 & 71.453 & 47.59887 & 5.472496 & 71.453 & 28.04928 & 5.262417 \\
\hline Muslim & 70.035 & 45.88114 & 1.945553 & 70.035 & 1.911099 & 2.033082 & 70.035 & 14510201 & 2.033082 & 70.035 & 40702340 & 1.957097 \\
\hline No_CPM & 67.121 & 39.3414 & 10.22701 & 67.121 & 9.3532 & 10.22701 & 67.121 & 5.696678 & 5.616167 & 67.121 & 1758356 & 9.844788 \\
\hline Time & 6.172 & 0.2198784 & 0.375 & 6.172 & 0.000025 & 0.375 & 6.172 & 0.1338977 & 0.375 & 6.172 & 0.2960473 & 0.375 \\
\hline Observations & & 1025 & & & 1025 & & & 1025 & & & 1025 & \\
\hline
\end{tabular}


Table 2.6: Nonparametric local kernel estimates ${ }^{1}$ from the models of quality of governance. Estimates corresponding to the 25th, 50th, and 75th percentiles of the estimated parameter distribution are reported. (labeled as Q1, Q2, and Q3.)

\begin{tabular}{|c|c|c|c|c|c|c|c|c|c|}
\hline \multirow[b]{3}{*}{ Variable } & \multicolumn{9}{|c|}{ Dependent variable $^{2}$} \\
\hline & \multicolumn{3}{|c|}{ control of corruption } & \multicolumn{3}{|c|}{ rule of law } & \multicolumn{3}{|c|}{ regulatory quality } \\
\hline & Q1 & Q2 & Q3 & Q1 & Q2 & Q3 & Q1 & Q2 & Q3 \\
\hline Cratio & $\begin{array}{r}-0.071 \\
(0.020)\end{array}$ & $\begin{array}{r}-0.055 \\
(0.016)\end{array}$ & $\begin{array}{r}-0.043 \\
(0.014)\end{array}$ & $\begin{array}{r}-0.063 \\
(0.030)\end{array}$ & $\begin{array}{r}-0.0225 \\
(0.0127)\end{array}$ & $\begin{array}{r}-0.0198 \\
(0.0148)\end{array}$ & $\begin{array}{r}-0.0513 \\
(0.0254)\end{array}$ & $\begin{array}{c}-0.0233 \\
(0.017)\end{array}$ & $\begin{array}{r}-0.019 \\
(0.015)\end{array}$ \\
\hline Remitgdp & $\begin{array}{r}-0.011 \\
(0.008)\end{array}$ & $\begin{array}{r}-0.005 \\
(0.006)\end{array}$ & $\begin{array}{r}-0.004 \\
(0.006)\end{array}$ & $\begin{array}{r}-0.0059 \\
(0.008)\end{array}$ & $\begin{array}{r}-0.0040 \\
(0.006)\end{array}$ & $\begin{array}{r}-0.0037 \\
(0.006)\end{array}$ & $\begin{array}{r}-0.0082 \\
(0.0076)\end{array}$ & $\begin{array}{r}-0.0063 \\
(0.006)\end{array}$ & $\begin{array}{r}-0.0058 \\
(0.006)\end{array}$ \\
\hline Lgdppc & $\begin{array}{r}0.385 \\
(0.079)\end{array}$ & $\begin{array}{r}0.527 \\
(0.097)\end{array}$ & $\begin{array}{r}0.954 \\
(0.081)\end{array}$ & $\begin{array}{r}0.0815 \\
(0.095)\end{array}$ & $\begin{array}{r}0.2332 \\
(0.087)\end{array}$ & $\begin{array}{r}0.6078 \\
(0.071)\end{array}$ & $\begin{array}{c}0.0144 \\
(0.099)\end{array}$ & $\begin{array}{c}0.2172 \\
(0.039)\end{array}$ & $\begin{array}{r}0.6301 \\
(0.061)\end{array}$ \\
\hline Energy & $\begin{array}{r}-0.0033 \\
(0.0047)\end{array}$ & $\begin{array}{r}-0.0024 \\
(0.0046)\end{array}$ & $\begin{array}{r}-0.0023 \\
(0.0046)\end{array}$ & $\begin{array}{r}-0.004 \\
(0.0047)\end{array}$ & $\begin{array}{r}-0.003 \\
(0.004)\end{array}$ & $\begin{array}{r}-0.003 \\
(0.004)\end{array}$ & $\begin{array}{r}-0.0014 \\
(0.00480)\end{array}$ & $\begin{array}{r}-0.0010 \\
(0.0047)\end{array}$ & $\begin{array}{r}-0.0010 \\
(0.0047)\end{array}$ \\
\hline Open & $\begin{array}{r}0.0043 \\
(0.0040)\end{array}$ & $\begin{array}{r}0.0045 \\
(0.0019)\end{array}$ & $\begin{array}{r}0.0048 \\
(0.0011)\end{array}$ & $\begin{array}{r}0.003 \\
(0.0016)\end{array}$ & $\begin{array}{r}0.005 \\
(0.0014)\end{array}$ & $\begin{array}{r}0.008 \\
(0.0013)\end{array}$ & $\begin{array}{r}0.0012 \\
(0.0027)\end{array}$ & $\begin{array}{r}0.0022 \\
(0.0014)\end{array}$ & $\begin{array}{r}0.004 \\
(0.0012)\end{array}$ \\
\hline Ethnic & $\begin{array}{r}-1.742 \\
(0.2085)\end{array}$ & $\begin{array}{r}-1.392 \\
(.1723)\end{array}$ & $\begin{array}{r}-1.274 \\
(0.1892)\end{array}$ & $\begin{array}{r}-1.59 \\
(0.189)\end{array}$ & $\begin{array}{r}-1.294 \\
(0.166)\end{array}$ & $\begin{array}{r}-0.855 \\
(0.378)\end{array}$ & $\begin{array}{r}-0.957 \\
(0.339)\end{array}$ & $\begin{array}{r}-0.735 \\
(0.182)\end{array}$ & $\begin{array}{r}-0.624 \\
(0.393)\end{array}$ \\
\hline Lat_abs & $\begin{array}{r}0.1236 \\
(0.993)\end{array}$ & $\begin{array}{r}1.431 \\
(0.2799)\end{array}$ & $\begin{array}{r}2.076 \\
(0.3287)\end{array}$ & $\begin{array}{r}0.573 \\
(0.283)\end{array}$ & $\begin{array}{r}1.392 \\
(0.302)\end{array}$ & $\begin{array}{r}1.807 \\
(0.504)\end{array}$ & $\begin{array}{r}1.13 \\
(0.383)\end{array}$ & $\begin{array}{r}1.371 \\
(0.293)\end{array}$ & $\begin{array}{r}1.437 \\
(0.321)\end{array}$ \\
\hline Catholic & $\begin{array}{r}-0.0028 \\
(0.0022)\end{array}$ & $\begin{array}{r}-0.0011 \\
(0.0016)\end{array}$ & $\begin{array}{r}-0.0009 \\
(0.0014)\end{array}$ & $\begin{array}{r}-0.006 \\
(0.002)\end{array}$ & $\begin{array}{r}-0.0008 \\
(0.001)\end{array}$ & $\begin{array}{r}-0.0007 \\
(0.001)\end{array}$ & $\begin{array}{r}-0.0021 \\
(0.00150)\end{array}$ & $\begin{array}{r}-0.0021 \\
(0.0014)\end{array}$ & $\begin{array}{r}-0.0012 \\
(0.0019)\end{array}$ \\
\hline Muslim & $\begin{array}{r}-0.0033 \\
(0.0014)\end{array}$ & $\begin{array}{r}-0.0025 \\
(0.0014)\end{array}$ & $\begin{array}{r}-0.0025 \\
(0.0014)\end{array}$ & $\begin{array}{r}-0.0013 \\
(0.0014)\end{array}$ & $\begin{array}{r}-0.0008 \\
(0.0013)\end{array}$ & $\begin{array}{r}-0.0007 \\
(0.0013)\end{array}$ & $\begin{array}{r}-0.0015 \\
(0.0014)\end{array}$ & $\begin{array}{r}-0.0008 \\
(0.0014)\end{array}$ & $\begin{array}{r}-0.0008 \\
(0.0014)\end{array}$ \\
\hline No_CPM & $\begin{array}{c}-0.0084 \\
(0.0015)\end{array}$ & $\begin{array}{r}-0.0008 \\
(0.0013)\end{array}$ & $\begin{array}{r}0.0002 \\
(0.0013)\end{array}$ & $\begin{array}{c}-0.0034 \\
(0.0014)\end{array}$ & $\begin{array}{r}-0.0003 \\
(0.0012)\end{array}$ & $\begin{array}{r}0.0002 \\
(0.0013)\end{array}$ & $\begin{array}{r}-0.0049 \\
(0.0017)\end{array}$ & $\begin{array}{r}-0.0013 \\
(0.0014)\end{array}$ & $\begin{array}{r}-0.0052 \\
(0.0012)\end{array}$ \\
\hline Time & $\begin{array}{r}-0.0061 \\
(0.0183)\end{array}$ & $\begin{array}{r}0.0043 \\
(0.0159)\end{array}$ & $\begin{array}{r}0.0049 \\
(0.0141)\end{array}$ & $\begin{array}{r}-0.0178 \\
(0.015)\end{array}$ & $\begin{array}{r}-0.0108 \\
(0.014)\end{array}$ & $\begin{array}{r}-0.0086 \\
(0.018)\end{array}$ & $\begin{array}{r}-0.029 \\
(0.015)\end{array}$ & $\begin{array}{r}-0.016 \\
(0.016)\end{array}$ & $\begin{array}{r}-0.010 \\
(0.021)\end{array}$ \\
\hline $\begin{array}{l}\text { Observations } \\
R^{2}\end{array}$ & & $\begin{array}{r}1025 \\
0.959 \\
\end{array}$ & & & $\begin{array}{r}1025 \\
0.956 \\
\end{array}$ & & & $\begin{array}{r}1025 \\
0.941 \\
\end{array}$ & \\
\hline $\begin{array}{l}\text { Bootstrap } \\
1 \text { The part } \\
2 \text { Estimate }\end{array}$ & dard & rs in $\mathrm{r}$ & ithes & ren & 100 & 5 & 61 & n. & \\
\hline
\end{tabular}


Table 2.7: Nonlinearity in remittances and consumption expenditures ratio. Nonapametric local kernel estimates ${ }^{1}$ for consumption expenditures ratio and remittances from the models of quality of governance. Estimates corresponding to the 25th, 50th, and 75 th percentiles of the estimated parameter distribution are reported. (labeled as Q1, Q2, and Q3.)

\begin{tabular}{|c|c|c|c|c|c|c|c|c|c|}
\hline \multirow[b]{3}{*}{ Variable } & \multicolumn{6}{|c|}{ Dependent variable $^{2}$} & \multirow{2}{*}{\multicolumn{3}{|c|}{ regulatory quality }} \\
\hline & \multicolumn{3}{|c|}{ control of corruption } & \multicolumn{3}{|c|}{ rule of law } & & & \\
\hline & Q1 & Q2 & Q3 & Q1 & $\mathrm{Q} 2$ & Q3 & Q1 & Q2 & Q3 \\
\hline Cratio $\leq q 1$ & $\begin{array}{r}-0.0702 \\
(0.020)\end{array}$ & $\begin{array}{r}-0.0531 \\
(0.016)\end{array}$ & $\begin{array}{r}-0.0419 \\
(0.014)\end{array}$ & $\begin{array}{r}-0.067 \\
(0.032)\end{array}$ & $\begin{array}{r}-0.022 \\
(0.017)\end{array}$ & $\begin{array}{r}-0.020 \\
(0.013)\end{array}$ & $\begin{array}{r}-0.053 \\
(0.052)\end{array}$ & $\begin{array}{r}-0.022 \\
(0.016)\end{array}$ & $\begin{array}{r}-0.019 \\
(0.014)\end{array}$ \\
\hline $\mathrm{q} 1<$ Cratio $\leq q 2$ & $\begin{array}{r}-0.0631 \\
(0.018)\end{array}$ & $\begin{array}{r}-0.0534 \\
(0.016)\end{array}$ & $\begin{array}{c}-0.0424 \\
(0.014)\end{array}$ & $\begin{array}{r}-0.0517 \\
(0.027)\end{array}$ & $\begin{array}{r}-0.0212 \\
(0.013)\end{array}$ & $\begin{array}{r}-0.0198 \\
(0.013)\end{array}$ & $\begin{array}{r}-0.0487 \\
(0.024)\end{array}$ & $\begin{array}{r}-0.0224 \\
(0.016)\end{array}$ & $\begin{array}{r}-0.0188 \\
(0.014)\end{array}$ \\
\hline $\mathrm{q} 2<$ Cratio $\leq q 3$ & $\begin{array}{r}-0.0735 \\
(0.036)\end{array}$ & $\begin{array}{r}-0.0603 \\
(0.017)\end{array}$ & $\begin{array}{r}-0.0447 \\
(0.014)\end{array}$ & $\begin{array}{r}-0.0606 \\
(0.030)\end{array}$ & $\begin{array}{r}-0.0264 \\
(0.019)\end{array}$ & $\begin{array}{r}-0.0202 \\
(0.013)\end{array}$ & $\begin{array}{r}-0.053 \\
(0.063)\end{array}$ & $\begin{array}{r}-0.029 \\
(0.019)\end{array}$ & $\begin{array}{r}-0.019 \\
(0.014)\end{array}$ \\
\hline Cratio $>$ q3 & $\begin{array}{l}-0.076 \\
(0.034)\end{array}$ & $\begin{array}{l}-0.055 \\
(0.016)\end{array}$ & $\begin{array}{r}-0.044 \\
(0.014)\end{array}$ & $\begin{array}{r}-0.063 \\
(0.031)\end{array}$ & $\begin{array}{c}-0.0234 \\
(0.017)\end{array}$ & $\begin{array}{c}-0.0194 \\
(0.013)\end{array}$ & $\begin{array}{r}-0.051 \\
(0.048)\end{array}$ & $\begin{array}{l}-0.023 \\
(0.016)\end{array}$ & $\begin{array}{r}-0.019 \\
(0.014)\end{array}$ \\
\hline Remitgdp $\leq q 1$ & $\begin{array}{l}-0.019 \\
(0.011)\end{array}$ & $\begin{array}{r}0.0057 \\
(0.006)\end{array}$ & $\begin{array}{r}0.0045 \\
(0.006)\end{array}$ & $\begin{array}{r}-0.009 \\
(0.010)\end{array}$ & $\begin{array}{l}-0.004 \\
(0.006)\end{array}$ & $\begin{array}{l}-0.004 \\
(0.006)\end{array}$ & $\begin{array}{r}-0.010 \\
(0.009)\end{array}$ & $\begin{array}{l}-0.006 \\
(0.006)\end{array}$ & $\begin{array}{r}-0.005 \\
(0.006)\end{array}$ \\
\hline $\mathrm{q} 1<$ Remitgdp $\leq q 2$ & $\begin{array}{l}-0.017 \\
(0.010)\end{array}$ & $\begin{array}{r}-0.0086 \\
(0.007)\end{array}$ & $\begin{array}{r}-0.0047 \\
(0.006)\end{array}$ & $\begin{array}{r}-0.010 \\
(0.011)\end{array}$ & $\begin{array}{r}-0.005 \\
(0.007)\end{array}$ & $\begin{array}{l}-0.004 \\
(0.006)\end{array}$ & $\begin{array}{r}-0.012 \\
(0.011)\end{array}$ & $\begin{array}{l}-0.008 \\
(0.007)\end{array}$ & $\begin{array}{r}-0.006 \\
(0.006)\end{array}$ \\
\hline $\mathrm{q} 2<$ Remitgdp $\leq q 3$ & $\begin{array}{l}-0.011 \\
(0.008)\end{array}$ & $\begin{array}{c}-0.0054 \\
(0.006)\end{array}$ & $\begin{array}{r}-0.0045 \\
(0.006)\end{array}$ & $\begin{array}{l}-0.006 \\
(0.029)\end{array}$ & $\begin{array}{c}-0.004 \\
(0.022)\end{array}$ & $\begin{array}{l}-0.003 \\
(0.006)\end{array}$ & $\begin{array}{r}-0.008 \\
(0.007)\end{array}$ & $\begin{array}{l}-0.006 \\
(0.006)\end{array}$ & $\begin{array}{r}-0.006 \\
(0.006)\end{array}$ \\
\hline Remitgdp $>$ q3 & $\begin{array}{r}-0.009 \\
(0.007)\end{array}$ & $\begin{array}{l}-0.005 \\
(0.006)\end{array}$ & $\begin{array}{r}-0.004 \\
(0.006)\end{array}$ & $\begin{array}{r}-0.005 \\
(0.007)\end{array}$ & $\begin{array}{r}-0.004 \\
(0.006)\end{array}$ & $\begin{array}{l}-0.003 \\
(0.006)\end{array}$ & $\begin{array}{r}-0.008 \\
(0.007)\end{array}$ & $\begin{array}{l}-0.006 \\
(0.006)\end{array}$ & $\begin{array}{r}-0.006 \\
(0.006)\end{array}$ \\
\hline $\begin{array}{l}\text { Observations } \\
R^{2}\end{array}$ & & $\begin{array}{r}1025 \\
0.959\end{array}$ & & & $\begin{array}{r}1025 \\
0.956\end{array}$ & & & $\begin{array}{r}1025 \\
0.941\end{array}$ & \\
\hline $\begin{array}{l}\text { Bootstrap stand } \\
\text { and upper quart } \\
1 \text { The partial eff } \\
2 \text { Estimates fron }\end{array}$ & $\begin{array}{l}\text { erro } \\
\text { for c } \\
\text { s are } \\
\text { egress }\end{array}$ & $\begin{array}{l}\text { u pare } \\
\text { umpti } \\
\text { ained } \\
\text { of fre }\end{array}$ & $\begin{array}{l}\text { expen } \\
\text { holdi } \\
\text { om fro }\end{array}$ & rrupti & $\begin{array}{l}\text { repr } \\
\text { ind re } \\
\text { gressc } \\
\text { are ec }\end{array}$ & $\begin{array}{l}\text { at lov } \\
\text { tance } \\
\text { at the } \\
\text { alent }\end{array}$ & $\begin{array}{l}\text { artile, } \\
\text { dian. } \\
\text { report }\end{array}$ & dian, & \\
\hline
\end{tabular}


Table 2.8: Remittances, household and government consumption expenditures, and consumption expenditures ratio: Nonparametric local kernel estimates ${ }^{1}$. Estimates corresponding to the 25th, 50th, and 75th percentiles of the estimated parameter distribution are reported. (labeled as Q1, Q2, and Q3.)

\begin{tabular}{|c|c|c|c|c|c|c|c|c|c|}
\hline \multirow[b]{3}{*}{ Variable } & \multicolumn{9}{|c|}{ Dependent variable } \\
\hline & \multicolumn{3}{|c|}{ household consumption } & \multicolumn{3}{|c|}{ government consumption } & \multicolumn{3}{|c|}{ consumption exp. ratio } \\
\hline & Q1 & $\mathrm{Q} 2$ & Q3 & Q1 & Q2 & Q3 & Q1 & Q2 & Q3 \\
\hline Remitgdp & $\begin{array}{r}0.029 \\
(0.142)\end{array}$ & $\begin{array}{r}0.053 \\
(0.145)\end{array}$ & $\begin{array}{r}0.251 \\
(0.191)\end{array}$ & $\begin{array}{r}-0.0697 \\
(0.0506)\end{array}$ & $\begin{array}{r}-0.0464 \\
(0.0439)\end{array}$ & $\begin{array}{r}-0.0408 \\
(0.0433)\end{array}$ & $\begin{array}{r}0.0132 \\
(0.0188)\end{array}$ & $\begin{array}{r}0.0166 \\
(0.0191)\end{array}$ & $\begin{array}{r}0.0351 \\
(0.0237)\end{array}$ \\
\hline Lgdppc & $\begin{array}{c}-17.550 \\
(2.133)\end{array}$ & $\begin{array}{r}-8.069 \\
(1.763)\end{array}$ & $\begin{array}{r}-2.805 \\
(0.081)\end{array}$ & $\begin{array}{r}0.0224 \\
(0.0438)\end{array}$ & $\begin{array}{c}0.9914 \\
(0.555)\end{array}$ & $\begin{array}{r}4.467 \\
(0.595)\end{array}$ & $\begin{array}{c}-2.463 \\
(0.259)\end{array}$ & $\begin{array}{r}-0.7868 \\
(0.311)\end{array}$ & $\begin{array}{r}-0.1771 \\
(0.159)\end{array}$ \\
\hline Energy & $\begin{array}{r}0.047 \\
(0.1070)\end{array}$ & $\begin{array}{r}0.047 \\
(0.1072)\end{array}$ & $\begin{array}{r}0.057 \\
(0.108)\end{array}$ & $\begin{array}{r}-0.0395 \\
(0.0343)\end{array}$ & $\begin{array}{r}-0.0282 \\
(0.0326)\end{array}$ & $\begin{array}{r}-0.0276 \\
(0.0326)\end{array}$ & $\begin{array}{r}0.0117 \\
(0.0142)\end{array}$ & $\begin{array}{r}0.0118 \\
(0.0142)\end{array}$ & $\begin{array}{r}0.015 \\
(0.0146)\end{array}$ \\
\hline Open & $\begin{array}{r}-0.0908 \\
(0.0373)\end{array}$ & $\begin{array}{r}-0.0526 \\
(0.0328)\end{array}$ & $\begin{array}{r}0.0606 \\
(0.0289)\end{array}$ & $\begin{array}{r}-0.0102 \\
(0.0093)\end{array}$ & $\begin{array}{r}0.0315 \\
(0.0098)\end{array}$ & $\begin{array}{r}0.0423 \\
(0.0116)\end{array}$ & $\begin{array}{r}-0.0176 \\
(0.0053)\end{array}$ & $\begin{array}{r}-0.0119 \\
(0.0043)\end{array}$ & $\begin{array}{r}0.0055 \\
(0.0035)\end{array}$ \\
\hline Ethnic & $\begin{array}{r}-0.3342 \\
(12.060)\end{array}$ & $\begin{array}{r}7.684 \\
(3.215)\end{array}$ & $\begin{array}{r}19.31 \\
(4.143)\end{array}$ & $\begin{array}{r}-3.362 \\
(1.177)\end{array}$ & $\begin{array}{r}0.9564 \\
(1.482)\end{array}$ & $\begin{array}{c}10.220 \\
(2.862)\end{array}$ & $\begin{array}{r}-3.313 \\
(1.579)\end{array}$ & $\begin{array}{r}1.109 \\
(0.518)\end{array}$ & $\begin{array}{r}1.188 \\
(0.609)\end{array}$ \\
\hline Lat_abs & $\begin{array}{c}-39.470 \\
(7.517)\end{array}$ & $\begin{array}{r}-20.72 \\
(6.437)\end{array}$ & $\begin{array}{r}11.70 \\
(7.533)\end{array}$ & $\begin{array}{r}-1.455 \\
(2.412)\end{array}$ & $\begin{array}{r}8.903 \\
(1.967)\end{array}$ & $\begin{array}{r}15.430 \\
(3.412)\end{array}$ & $\begin{array}{r}-7.146 \\
(1.101)\end{array}$ & $\begin{array}{r}-3.953 \\
(0.857)\end{array}$ & $\begin{array}{r}1.382 \\
(0.997)\end{array}$ \\
\hline Catholic & $\begin{array}{r}0.0678 \\
(0.0366)\end{array}$ & $\begin{array}{r}0.0688 \\
(0.0355)\end{array}$ & $\begin{array}{r}0.0847 \\
(0.0306)\end{array}$ & $\begin{array}{r}-0.0395 \\
(0.0091)\end{array}$ & $\begin{array}{r}-0.0151 \\
(0.0097)\end{array}$ & $\begin{array}{r}-0.0056 \\
(0.0107)\end{array}$ & $\begin{array}{r}0.0052 \\
(0.0047)\end{array}$ & $\begin{array}{r}0.0087 \\
(0.0042)\end{array}$ & $\begin{array}{r}0.0202 \\
(0.0045)\end{array}$ \\
\hline Muslim & $\begin{array}{r}0.0834 \\
(0.0321)\end{array}$ & $\begin{array}{r}0.0835 \\
(0.0321)\end{array}$ & $\begin{array}{r}0.0979 \\
(0.0328)\end{array}$ & $\begin{array}{r}-0.0401 \\
(0.0101)\end{array}$ & $\begin{array}{r}-0.0325 \\
(0.0096)\end{array}$ & $\begin{array}{r}-0.0325 \\
(0.0096)\end{array}$ & $\begin{array}{r}0.01463 \\
(0.0042)\end{array}$ & $\begin{array}{r}0.01463 \\
(0.0042)\end{array}$ & $\begin{array}{r}0.0179 \\
(0.0044)\end{array}$ \\
\hline No_CPM & $\begin{array}{r}-0.0760 \\
(0.0333)\end{array}$ & $\begin{array}{r}0.0118 \\
(0.0329)\end{array}$ & $\begin{array}{r}0.0282 \\
(0.0316)\end{array}$ & $\begin{array}{r}-0.0649 \\
(0.0095)\end{array}$ & $\begin{array}{r}-0.0514 \\
(0.0111)\end{array}$ & $\begin{array}{r}-0.0396 \\
(0.0119)\end{array}$ & $\begin{array}{r}0.0092 \\
(0.0050)\end{array}$ & $\begin{array}{r}0.0106 \\
(0.0044)\end{array}$ & $\begin{array}{r}0.0239 \\
(0.0046)\end{array}$ \\
\hline Time & $\begin{array}{r}-0.2098 \\
(0.3734)\end{array}$ & $\begin{array}{r}-0.0215 \\
(0.3424)\end{array}$ & $\begin{array}{r}0.8338 \\
(0.3730)\end{array}$ & $\begin{array}{r}-0.1898 \\
(0.1123)\end{array}$ & $\begin{array}{r}-0.0408 \\
(0.1120)\end{array}$ & $\begin{array}{r}0.0811 \\
(0.1242)\end{array}$ & $\begin{array}{r}0.0051 \\
(0.057)\end{array}$ & $\begin{array}{r}0.0175 \\
(0.045)\end{array}$ & $\begin{array}{r}0.0640 \\
(0.051)\end{array}$ \\
\hline $\begin{array}{l}\text { Observations } \\
R^{2}\end{array}$ & & $\begin{array}{r}1025 \\
0.928\end{array}$ & & & $\begin{array}{r}1025 \\
0.886\end{array}$ & & & $\begin{array}{r}1025 \\
0.882\end{array}$ & \\
\hline
\end{tabular}

Bootstrap standard errors in parentheses.

1 The partial effect estimates are obtained by holding all other regressors at their median. 
Table 2.9: Nonparametric percentile estimates for remittances from regressions in Table 2.8, but at some specific ranges of the coefficient distribution.

\begin{tabular}{|c|c|c|c|c|c|}
\hline \multirow{2}{*}{$\begin{array}{l}\text { Dependent variable: } \\
\text { household consumption }\end{array}$} & \multicolumn{5}{|c|}{ Percentiles } \\
\hline & 75 th & 80 th & 85 th & 90th & 95th \\
\hline \multirow[t]{2}{*}{ Remitgdp } & 0.251 & 0.455 & 0.757 & 1.234 & 2.155 \\
\hline & $(0.191)$ & $(0.0235)$ & $(0.299)$ & $(0.398)$ & $(0.601)$ \\
\hline & \multicolumn{5}{|c|}{ Percentiles } \\
\hline $\begin{array}{l}\text { Dependent variable: } \\
\text { government consumption }\end{array}$ & 5 th & 10th & 15 th & 20 th & 25 th \\
\hline \multirow[t]{2}{*}{ Remitgdp } & -0.199 & -0.1506 & -0.1117 & -0.0808 & -0.0697 \\
\hline & $(0.1202)$ & $(0.085)$ & $(0.067)$ & $(0.054)$ & $(0.0506)$ \\
\hline & \multicolumn{5}{|c|}{ Percentiles } \\
\hline $\begin{array}{l}\text { Dependent variable: } \\
\text { consumption exp. ratio }\end{array}$ & 75 th & 80th & 85 th & 90th & 95th \\
\hline \multirow[t]{2}{*}{ Remitgdp } & 0.0351 & 0.0563 & 0.0794 & 0.1332 & 0.1824 \\
\hline & $(0.023)$ & $(0.029)$ & $(0.035)$ & $(0.052)$ & $(0.069)$ \\
\hline
\end{tabular}

Table 2.10: Nonparametric partial estimates for remittances from the regression model of government consumption expenditure in Table 2.8, obtained by splitting remittances data values into four groups by its quartiles. Reported estimates, denoted by Q1, Q2, and Q3, are the quartile values for each of the four groups.

\begin{tabular}{lccc}
\hline \hline \multirow{2}{*}{ Variable/level } & \multicolumn{2}{c}{ Dependent variable: control of corruption } & Q3 \\
\cline { 2 - 4 } Remitgdp $\leq q 1$ & -0.0749 & -0.0469 & -0.0405 \\
& $(0.052)$ & $(0.043)$ & $(0.043)$ \\
q1 $<$ Remitgdp $\leq q 2$ & -0.0781 & -0.0454 & -0.0413 \\
& $(0.053)$ & $(0.043)$ & $(0.043)$ \\
q2 $<$ Remitgdp $\leq q 3$ & -0.0702 & -0.0450 & -0.0398 \\
& $(0.050)$ & $(0.043)$ & $(0.043)$ \\
Remitgdp $>$ q3 & -0.0603 & -0.0482 & -0.0422 \\
& $(0.047)$ & $(0.044)$ & $(0.043)$ \\
\hline Observations & & 1025 & \\
\hline Bootstrap standard errors in parentheses. ${ }^{1}$ Estimates for other explanatory variables are not reported. \\
Note: q1, q2, and q3 are the quartiles for remittances data values. \\
\hline
\end{tabular}


Table 2.11: Local constant bandwidths ${ }^{1}$ for the instrumental variables (IV) estimation.

\begin{tabular}{lrrrr}
\hline \hline & Dependent variable: control of corruption & \multicolumn{2}{c}{ Dependent variable: remittances } \\
\cline { 2 - 5 } Variable & UB & LC & UB & LC \\
\hline Cratio & 5.99 & 5.364492 & 5.99 & 4.96538000 \\
Remitgdp & 15.585 & 6.758626 & & \\
Lgdppc02 & 1.103 & 0.000984 & 1.103 & 0.552203 \\
Energy & 21.15 & 76079762 & 21.15 & 2.457601 \\
Open & 70.28 & 69364992 & 70.28 & 22.97405 \\
Ethnic & 0.47 & 0.097254 & 0.47 & 0.1660083 \\
Lnd100km & 0.672 & 158394 & 0.672 & 0.09880469 \\
Lat_abs & 0.352 & 35345.65 & 0.352 & 0.08044254 \\
Catholic & 71.453 & 11.20937 & 71.453 & 6.275609 \\
Muslim & 70.035 & 6179471 & 70.035 & 120.5691 \\
No_CPM & 67.121 & 6403198 & 67.121 & 118.3021 \\
Time & 6.172 & 0.217505 & 6.172 & 0.2722974 \\
\hline $\mathrm{n}$ & 1025 & & 1025 \\
\hline \hline & & & \\
but are not reported. &
\end{tabular}

Table 2.12: Partial effects estimates from the instrumental variables (IV) estimation ${ }^{1}$ for consumption expenditures ratio. Estimates corresponding to the 25th, 50th, and 75th percentiles of the estimated parameter distribution (labeled as Q1, Q2, and Q3) are reported. The partial effects are also presented by splitting the levels of the consumption expenditures ratio by its median value.

\begin{tabular}{lccc}
\hline \hline \multirow{2}{*}{ Variable/level } & \multicolumn{2}{c}{ Dependent variable: control of corruption } & Q3 \\
\cline { 2 - 4 } Cratio & -0.062 & $\mathrm{Q} 2$ & -0.060 \\
& $(0.028)$ & -0.061 & $(0.028)$ \\
Cratio $\leq q 2$ & -0.063 & $-0.027)$ & -0.059 \\
& $(0.028)$ & -0.061 & $(0.028)$ \\
Cratio $>$ q2 & -0.062 & $(0.027)$ & -0.060 \\
& $(0.028)$ & -0.061 & $(0.028)$ \\
\hline Observations & $(0.027)$ & 1025 \\
& & \\
\hline \hline Bootstrap standard errors in parentheses. ${ }^{1}$ Estimates for other explanatory variables are not reported. \\
Note: q2 is the median value of consumption expenditures ratio. \\
\hline
\end{tabular}


Table 2.13: Summary Statistics

\begin{tabular}{|c|c|c|c|c|c|}
\hline Variable name & Number of observations & Mean & "Standard deviation & Minimum & Maximum \\
\hline Remittances (\% of GDP) & 1025 & 5.115311 & 7.792558 & 0.000039 & 59.3088 \\
\hline Consumption expenditures ratio & 1025 & 5.625744 & 2.99483 & 1.180914 & 24.10644 \\
\hline Log of GDP (in constant US\$) & 1025 & 3.298645 & 0.5514861 & 2.124374 & 4.464248 \\
\hline Energy depletion ( $\%$ of GNI) & 1025 & 5.034874 & 10.57469 & 0 & 83.2803 \\
\hline Open (sum of imports and exports, \% of GDP) & 1025 & 82.90656 & 35.13784 & 22.1183 & 210.374 \\
\hline Ethinic fractionalization & 1025 & 0.4842346 & 0.2333098 & 0.002 & 0.9302 \\
\hline Latitude & 1025 & 0.2734577 & 0.1757839 & 0.0111111 & 0.6666667 \\
\hline Coastal area ( $\%$ of total area) & 1025 & 0.3164137 & 0.3361212 & 0 & 1 \\
\hline Catholic (\% of total population) & 1025 & 29.93102 & 35.72647 & 0 & 96.6 \\
\hline Muslim (\% of total population) & 1025 & 25.11464 & 35.01772 & 0 & 99.4 \\
\hline Protestant ( $\%$ of total population) & 1025 & 6.646244 & 12.30759 & 0 & 66 \\
\hline No_CPM (other religions, $\%$ of total population) & 1025 & 38.30809 & 33.56066 & 0.3999985 & 100 \\
\hline British legal origin & 1025 & 0.2439024 & 0.4296442 & 0 & 1 \\
\hline Socialist legal origin & 1025 & 0.2887805 & 0.4534169 & 0 & 1 \\
\hline German commercial code & 1025 & 0.0107317 & 0.1030869 & 0 & 1 \\
\hline French commercial code & 1025 & 0.4565854 & 0.4983548 & 0 & 1 \\
\hline Control of corruption & 1025 & -0.3591221 & 0.6492613 & -1.5242 & 2.4622 \\
\hline Rule and law & 1025 & -0.3513665 & 0.6771783 & -1.78744 & 1.93633 \\
\hline Regulatory quality & 1025 & -0.1653386 & 0.6934012 & -1.69172 & 1.96706 \\
\hline Freedom from corruption & 1025 & 32.8722 & 14.42966 & 4 & 96 \\
\hline Informal payment to officials & 42 & 1.308803 & 0.3209333 & 0.447158 & 1.858357 \\
\hline
\end{tabular}




\section{Chapter 3}

\section{Do Remittances Promote Financial}

\section{Inclusion?*}

\subsection{Introduction}

In recent years, the provision of financial services has been considered as the most useful mechanism for reducing poverty in developing countries. Such a provision of financial services to households is termed as financial inclusion. Fully inclusive financial system offering a wide range of services including savings, credit, payment, and insurance is expected to provide much benefits to poor households, ethnic groups, and rural communities. Conroy (2008) argues that financial inclusion focuses attention on the need to bring previously excluded people under the umbrella of financial institutions. The Center for Financial Inclusion (CFI) defines full financial inclusion as a state in which everyone who can use them has access to a range of quality financial services at affordable prices, with convenience, dignity, and consumer protections, delivered by a range of providers in a stable, competitive market to financially capable clients.

${ }^{*}$ I would like to thank my advisor, Prof. Feng Yao, for his guidance throughout this research work. I am thankful to Prof. Stratford Douglas, Prof. Arabinda Basistha, Prof. Andrew Young, and Prof. Philip Michelbach for their constructive comments and suggestions. All remaining errors are mine. 
In this essay, we take up an important research question of whether the inflow of remittances promotes financial inclusion in the recipient countries. Our measure of financial inclusion comes from two aspects of financial inclusion: 'access' and 'usage' of formal financial services. In general, access and usage are the two basic dimensions of financial inclusion. Access refers to the ability to use the services and products offered by formal financial institutions. Determining levels of access may require identifying and analyzing potential barriers to opening and using a bank account. Rather than using intangible measures of access, we directly use the "percentage of people having an account at a formal financial institution " across countries to incorporate the access dimension. Usage refers to the depth or extent of financial services and product use. Determining usage requires gathering details about the regularity, frequency and duration of use over time (FIDWG, AFI, 2013). With respect to the usage dimension, we use the "percentage of people that have saved some money at a formal financial institution in the past year" across countries.

Several studies and country experiences show that the expansion of financial access and promotion of banking habit among the people help expand economic activities. Many governments around the world have devised policy measures to promote branchless banking and mobile banking to increase people's access to financial services. Branchless banking is a distribution channel strategy used for delivering financial services to the grass roots of the economy that does not rely on bank branches. Other such policies as facilitating saving and credit cooperatives in particular, are believed to be an important mechanism in generating employment, increasing income, and alleviating poverty. These measures help ensure the participation of poor households, disadvantaged groups, and rural communities into the main stream of the financial system.

As an increased level of financial inclusion supports both economic efficiency and equity, remittances may have potential impacts on economic growth and development through their contribution to financial deepening and more equitable distribution. Though the literature paid much attention to the effects of remittances on financial development (Agarwal et al., 
2012), poverty (Adams and Page, 2005; Acosta et al., 2007; Gupta et al., 2009), health and education (Cox-Edwards and Ureta, 2003; Amuedo-Dorantes et al., 2007), consumption (Rempel and Lodbell, 1977; Adams and Page, 2005), investment and growth (Yang, 2005; Giuliano and Ruiz-Arranz, 2009; Dupas and Robinson, 2009); their impact on financial inclusion has relatively been ignored. The receipts of remittances are expected to enhance the financial resources of the recipient households, thereby leading to increased demand for several kinds of financial services and products from the formal financial institutions.

When households receive remittances, the first thing they do usually include paying off the loans they have owed. As remittances are sent in installments with varying frequencies, the recipient households would like to store the money at a safer place so as to use it once needs arise. The households may use the money to purchase goods and services such as basic necessities, durable items and luxury goods, and utility bills. The money could be used to pay for children's school fees and uniform, books, and other similar materials. Households may require to put some money aside to pay the doctor's bill in case its family members get sick. By adding to remittances income over time, household can accumulate funds to buy housing or to finance business investment. In sum, remittances may increase households' demands for savings account, payment and insurance services, and credit instruments. On the flip side, however, remittances may drive up consumption expenditure, lower savings, and reduce the demands for financial products and services as persistence flow of remittances might provide households insurance against future income shocks. Also, depending upon the social norms and practices, customs, and level of financial development, demand for traditional means of financial products and services may rise when remittances increase, thereby lowering the scope of formal financial institutions.

Anzoategui et al. (2013) claim that remittances could potentially affect financial inclusion in several ways. The fixed costs of sending remittances can make these flows lumpy. As a result, households possess excess cash for some period of time. This leads to increased demand for deposit accounts from formal financial institutions. Similarly, processing remittances 
flows provide financial institutions with information on the income of recipient households that might make those institutions better willing and able to extend loans to otherwise opaque borrowers. However, if remittances help relax households' financing constraints, the demand for credit instruments might fall with the rise in remittances.

The rest of this essay is organized as follows. Section 3.2 reviews major issues in financial inclusion literature in relation to remittances. Section 3.3 presents our empirical approach, thereby highlighting the importance of semiparametric partially linear model (PLM) in the analysis along with a brief description of the data and variables. The empirical findings are discussed in section 3.4 and section 3.5 concludes.

\subsection{Literature review}

The issue of inclusive finance has always been on the focus of many governments around the world. Policy makers and researchers have been concerned with this issue for years because of its perceived benefits. In the past decade, the multilateral agencies have promoted this issue as a means to improve economic growth, to reduce poverty, and promote social inclusion. Recently financial inclusion is even described as a complementary process to combat money laundering and terrorist financing (Koker Jentzsch, p.268, 2013). This is because the use of formal financial services increases transparency, thereby increasing the monitoring and surveillance capabilities of law enforcement agencies.

With rapid growth of technology in financial transactions, financial inclusion has been combined with mobile banking, SIM card registration, and other modern means of transactions as well. In this essay, however, financial inclusion is considered in a very general sense-process of ensuring the access and usage of formal financial services and products by those who are willing but not able to do so yet. Sarma and Pais (2008) define financial inclusion as a process that ensures the ease of access, availability, and usage of the formal financial system for all members of an economy. It has been estimated that about 2.5 billion 
working-age adult globally are unbanked, and do not have access to the types of formal financial services delivered by regulated financial institutions. In the context of Africa, less than a quarter of adults have an account with a formal financial institution and that many adults use informal methods to save and borrow (Kunt and Klapper, World Bank, 2012). The reasons of being unbanked include poverty, costs, travel distance, and often-burdensome requirements involved in opening an account (Projects and Operations, World Bank, 2013). This is a state of affairs of most of the developing countries with poor resources base and with a meager financial infrastructure.

In the context of substantial increase in size and rate of remittances inflows to the developing world for the last three decades, researchers have put more efforts to study the impacts of remittances on several economic variables. While previous research in the 1970s and 1980s was centered on the short-run effects of remittances, the research focus has shifted to the long-run impacts of remittances, especially in the dynamics of inequality, finance, entrepreneurship, and development (e.g., Rapoport \& Docquier, 2004). Recently, researchers and policymakers have emphasized the impact of remittances on financial inclusion. Empirical studies have shown that financial inclusion is associated with productive investment (Dupas and Rabinson, 2009), financial development (Toxopeus and Lensink, 2007), and overall economic development (Sarma and Pais, 2008). As financial deepening has a positive relationship with financial inclusion, studies have addressed the impacts of remittances in different aspects of financial sector development as well. Aggarwal et al. (2012) study the impacts of remittances on deposits and credits intermediated by local banking sector in developing countries and conclude that remittances promote financial development in developing countries.

Remittances received by households and small businesses are likely to increase the level and scope of financial resources available to them. Moreover, receiving remittances is a recurrent phenomenon for the recipients. The result may be increased demands of saving instruments in the form of deposit accounts in the remittances receiving country. Using 
household-level survey data for El Salvador, Anzoategui et al. (2013) finds that remittances have a positive impact on financial inclusion by promoting the use of deposit accounts, but they do not have a significant effect on the demand for and use of credit from formal institutions.

On the supply side, the role of government in bringing a larger proportion of the 'unbanked'population into the 'banked'sector can be significant. Governments of remittance recipient countries must be able to establish sound policy measures to improve the range of money transmission services provided to migrants through formal banking channels (Cooray A., 2012). Cooray finds that migrant remittances affect the size and efficiency of financial sector through government ownership of banks. He claims that government can lead to financial literacy programs and can improve infrastructure necessary for the provision of financial services that ultimately leads to financial inclusiveness.

Financial inclusion requires the existence of several financial institutions with sound regulatory framework. In such environment, they can collectively offer appropriate financial products and services to all segments of the population in an economy. The effective regulatory quality is vital for financial inclusion process. In most developing countries, financial services are only available to a minority of population. Mainstream for-profit financial institutions have largely ignored the segment of the market that includes the low income and poor households, as well as small- and medium-sized enterprises, often called the "missing middle" (United Nations, 2006).

In addition to persistent market imperfections, developing countries are characterized by other socio-economic dimensions such as high levels of poverty, income inequality, and income volatility. These factors require risk-diversification, consumption smoothing, and intergenerational financing of investment. This is the reason why the demand for and use of saving and credit instruments are so critical in such countries. Since remittances are likely to have important effects on each of these dimensions, their impacts on the economy and particularly on the process of financial inclusion are likely to be quite large. 
The effects of remittances on inclusive finance may not transpire in isolation. The level of financial development as well as the market oriented government policies may have direct impacts on financial sector outcomes. The financial sector policies of the government including its regulatory quality captures perceptions of the ability of the government to formulate and implement sound policies and regulations that permit and promote private sector development (WGI, World Bank). It measures the incidence of market-unfriendly policies. Unless ensuring the effectiveness of business friendly policies, financial sector remains vulnerable to greater risks and uncertainty. In such circumstances, the process of integrating households and small enterprises into formal financial sectors cannot be ensured.

The financial infrastructures in many developing countries are not only insufficient, but they are also extremely fragile. Because of the existence of high costs of receiving banking services, long travel distance, high poverty and lack of creditworthiness of lower income borrowers and small firms with little collateral, larger segments of population have been forced to undertake financial transactions with informal financial sectors. The inadequate financial infrastructure may create huge financial barriers on the part of individual households and small firms. With lower households income and wealth, these barriers may further jeopardize their needs as well as interests of joining with the formal financial sector. The higher remittances inflows might make financial transactions more profitable for many banking and financial institutions, which otherwise would continue to remain sluggish or would engage in speculative activities.

\subsection{Empirical methodology and data}

We investigate the relationship between remittances and financial inclusion by analyzing the following semiparametric partially linear model:

$$
\text { Financial inclusion }_{i}=g\left(Z_{i}\right)+X_{i}^{\prime} \beta+u_{i}, \quad i=0,1, \ldots, n \text {. }
$$


Where, $X_{i}$ is a $p \times 1$ vector, $\beta$ is a $p \times 1$ vector of unknown parameters, and the functional form of $g\left(Z_{i}\right)$ is left unspecified. The model specification (3.1) is described as semiparametric because it contains both finite-dimensional (i.e., parametric) component and infinite-dimensional (i.e., nonparametric) component. The data is assumed to be i.i.d. with $E\left(u_{i} \mid X_{i}, Z_{i}\right)=0$, and we allow for a conditionally heteroskedastic error process $E\left(u_{i}^{2} \mid x, z\right)=\sigma^{2}(x, z)$ of unknown form. The model (3.1) specifies conditional mean as linear in $X_{i}$ but nonlinear in $Z_{i}$ (remittances). Our goal is to estimate $\beta$ and $g($.$) consistently and$ to obtain the confidence intervals. Since $g($.$) is unconstrained, the identification condition$ is that elements of $X_{i}$ cannot be collinear with any function of remittances. This means that an intercept term cannot be identified in a partially linear model and is excluded from specification (3.1). The model specification (3.1) can be estimated by using the method of Robinson (1988).

We estimate the model (3.1) by controlling for a set of key socio-economic, legal, and infrastructural factors across countries represented by the matrix $X$ that the remittances literature has found to affect financial inclusion (e. g. Anzoategui et al., 2013; Sarma and Pais, 2008). For comparison purpose, however, we will also present the results by estimating the linear parametric versions of model (3.1).

The financial inclusion indicator variables come from the 2011 Global Financial Inclusion (Global Findex) Database compiled by the World Bank. Our dependent variable is a financial inclusion index which is computed from each of the following two key indicators of financial inclusion for every country in the dataset: 1) percentage of people having an account at a formal financial institution (regarded as an accessibility dimension of financial inclusion and considered as a proxy for the demand for deposit instruments), and 2) percentage of people who saved money into an account at a formal financial institution (regarded as a usage dimension of financial inclusion and considered as a proxy for the extent of using deposit instruments). A composite index of financial inclusion is also computed by combining these two indicators (see Appendix, Table 3.1, for details). 
The variable of interest is the inflow of personal remittances, received (\% of GDP). Remittances are defined as the sum of worker's remittances, compensation of employees, and migrant's transfers in the balance of payments. Workers' remittances are the current transfers made by migrants who are employed and resident in another country. Compensation of employees refers to the income of border, seasonal, and other short-term workers who are employed in an economy where they are not resident and of residents employed by nonresident entities. Finally, migrant transfers consist of the financial items that arise from the migration or change of residence of individuals from one country to another. The aggregated data for remittances come from WDI.

The control variables represented by matrix $X$ includes real GDP per capita, primary school enrollment (\% of gross), rural population (\% of total population), and telephone lines (per 100 people). These variables come from WDI. Similarly, it includes the legal origin variables (defined in terms of binary variables for British common law, Socialist/communist laws, and French, Germany, and Scandinavian commercial codes) that are obtained from the Center for International Development at Harvard University (CID).

Our cross-sectional dataset consists of 81 countries based on the availability of data that excludes the Group of Seven (G7) countries, Western European OECD countries, and Australia. The reason is that these countries are structurally different from the rest of the world regarding financial infrastructure and their responses to remittances. The data set is available from the authors upon request. A detail description of the variables is included in Appendix, Table 3.1.

The dependent variable 'financial inclusion' is computed using the methodology employed by Sarma (2008). This approach of calculating index of financial inclusion (IFI) is similar to that used by UNDP for computation of some well-known development indices such as the HDI (Human Development Index), the HPI (Human Poverty Index) etc. Accordingly, the index of financial inclusion (IFI) in this paper is computed first by calculating 
a dimension index, $d_{i}$, for a given dimension of financial inclusion by the following formula.

$$
d_{i}=\frac{A_{i}-m_{i}}{M_{i}-m_{i}} ; \quad 0 \leq d_{i} \leq 1
$$

Where, $i=1,2, \ldots, n ; A_{i}=$ actual value of dimension $\mathrm{i} ; m_{i}=$ lower limit for dimension $\mathrm{i}$, given by the observed minimum for dimension i; $M_{i}=$ upper limit for dimension i, given by the observed maximum for dimension i.

After calculating the dimension indexes, $d_{i}$, for various dimensions of financial inclusion in a country, the comprehensive index of financial inclusion (IFI) for the country, $i$, is calculated by using the following formula:

$$
I F I_{i}=1-\frac{\sqrt{\left(1-d_{1}\right)^{2}+\left(1-d_{2}\right)^{2}+\cdots+\left(1-d_{n}\right)^{2}}}{\sqrt{n}} ; \quad 0 \leq I F I_{i} \leq 1
$$

Finally, to ensure that the index ranges from $-\infty$ to $+\infty$ while still preserving the order, the "Financial Inclusion" index (dependent variable) in this analysis is derived from the expression (3.3) as follows:

$$
\text { Financial inclusion }_{i}=\ln \left(\frac{I F I_{i}}{1-I F I_{i}}\right)
$$

In the present analysis, either a single indicator of financial inclusion or a combination of two indicators of financial inclusion are used for computing the index of financial inclusion for a given country. It is because one of the objectives of this empirical study is to make a comparison of impact of remittances on each dimension of financial inclusion across countries.

\subsection{Empirical findings}

As described in section 3.3, the financial inclusion index (dependent variable) is computed from a particular indicator or set of indicators of financial inclusion. As our major goal is 
to examine the impact of remittances on the demand for and use of deposit instruments across countries, the result of analysis with a each individual dimension of financial inclusion indicator is very important for us. By taking this objective into consideration, we first consider the following two indicators of financial inclusion for a country as a whole: 1) account at a formal financial institution, (\% age 15+), and 2) saved at a financial institution in the past year (\% age $15+$ ). The first indicator is a proxy for the accessibility dimension (e.g. demand for deposit instruments so as to access the financial services) and the second indicator is a proxy for the usage dimension (e.g. saving money by making use of deposit instruments) of financial inclusion. We first compute a composite financial inclusion index by combining both of these indicators and study the impact of remittances on this aggregate index of financial inclusion. Then we compute a single dimensional index of financial inclusion by using each of the two indicators separately and study the impact of remittances on each individual dimension.

Table 3.2 presents the results of estimation of the semiparametric partially linear model (3.1) using the method of Robinson (1988). The dependent variable is the composite financial inclusion index for a country as a whole that is derived from two indicators of financial inclusion as described in the previous paragraph. The local linear quartile coefficients estimates for remittances are negative and statistically significant, though the coefficient variation is not too wide between lower and upper quartiles. This finding is against the general expectation that remittances lead to greater financial inclusion. From the results in the parametric part, we also find that real GDP per capita, British legal origin, and the telephone lines (a proxy for economic infrastructure) all are found to have positive and significant impact on financial inclusion as expected. The coefficient estimate with primary school enrollment (a proxy for education/literacy) appears with positive sign and the size of rural population appears with a negative coefficient, both are as expected.

we are basically interested in examining the impact of remittances separately on accessibility and usage dimension of financial inclusion across countries. We present the results 
of this analysis in Table 3.3 and Table 3.4. From local linear quartile coefficient estimates for remittances in Table 3.3, we find that remittances do not affect the demand for deposit instruments at the country level. However, results from Table 3.4 show that remittances have a significant negative impact on the use of deposit instruments across countries.

To strengthen our understanding of the potential differential impacts of remittances on the demand for deposit instruments and use of such instruments (i.e., savings), we analyze the relationship between remittances and these variables not only separately but also at the rural-sector and urban-sector, taken one at a time. This analysis is expected to shed light on how the behavior of remittance-recipient households in these two parts of an economy differs. Tables 3.5 to 3.10 present the results of such analyses. From the first three of these tables, tables 3.5 - 3.7, we find that while all other control variables have similar expected sign and significance level in almost every case, the local linear quartile coefficient estimates with remittances are found to be negative and statistically significant, indicating that remittances have adverse impact on the demand for deposit instruments and use of such instruments across rural regions of an economy. These findings are, therefore, in contrast with the results from remaining three tables, that is, tables $3.8-3.10$. In other words, remittances are not found to have any statistically significant impact on deposit instruments in the urban sector of an economy. We argue that remittance recipients in the rural regions are attracted more towards informal financing methods. Demirguc-Kunt and Klapper (2013) claim that use of informal and community-based saving methods (e. g. rotating saving clubs) are very widespread (such as in Cameroon, Nigeria, and Kenya). So when remittances inflow rise, the informal methods of saving might have become more popular than formal methods, thereby causing a decline in both the demand for deposit account and frequency of savings in rural areas. Moreover, rather than demanding deposit accounts at banks or other formal institutions, remittance-recipients might have loaned out money informally to their relatives, friends, neighbors, or other close connections with the hope of getting higher interest income because banks usually pay a very low rate of interest on deposits. 
In the second phase, we estimate linear parametric versions of above semiparametric models. Remittances variable is taken in 'levels' in these estimations. The resulting OLS estimates are presented in tables 3.11 - 3.13. The parameter estimate associated with remittances for the usage (of deposit instruments) dimension at the country-level is found to be negative and statistically significant at 1\% level. Although, for the country-level, coefficient estimates on remittances in models of composite index and accessibility dimension are negative, they are not statistically significant at convenient levels. The estimation outputs for these models using rural-sector data provide exactly the same conclusion as in the case of country-level data. However, the results from urban-sector data indicate a bit different scenario. None of the estimates associated with remittances are statistically significant, though they all come up with a negative sign. Overall, these parametric results provide a consistent and full supports for our findings from above semiparametric analysis.

In the third and final phase of analysis, we now estimate all the same models but now looking at the impact of change in remittances (as a \% of GDP) from one year to the next on the indexes of financial inclusion. That is, we address the issue of spurious regression and nonstationarity of remittances inflows by considering its first-differences. The estimated parameter coefficients are shown in tables 3.14 - 3.16. These results, still reinforcing our previous findings, however are quite more impressive. The estimates associated with remittances in all models and for all levels of data (e.g., country, rural, or urban) are negative and statistically significant, definitely indicating a more adverse impact of remittances on inclusive finance and the financial inclusion.

Taken together, the findings from our three phases of econometric analysis evidently suggest that the rural sectors across developing countries have been persistently facing the deficiency of financial infrastructures, and most of the people who have been migrated from the rural regions are still unable to access and use the financial services and products offered by the formal financial institutions. The reasons may include the existence of high costs of receiving banking services, long travel distance, high poverty and lack of creditworthiness of 
lower income borrowers and small firms with little assets and collateral. So we conjecture that the persistent inflow of remittances might provide the recipient households insurance against future income shocks, thereby causing a decline in savings, while at the same time pushing up the household consumption expenditure. Overall, the inflow of remittances alone are not found to promote financial inclusion in the developing countries.

\subsection{Concluding remarks}

In this essay, we examined the relationship between the inflow of remittances and financial inclusion across countries. Using cross-sectional data for 2011, we estimated the cross-country regression models by controlling the key socio-economic, legal, and infrastructural characteristics. We employed semiparametric partially linear model to allow the nonlinearity and heterogeneity in partial effects of remittances on financial inclusion. We find that remittances have a significant negative impact on savings across countries, but have no impact on the demand for saving instruments. Once the data is disaggregated at rural and urban levels, remittances are found to have adverse impacts on demand for deposit instruments and on savings in the rural sector, but not in the case of urban sector. These findings clearly suggest that the rural sector has been facing the deficiency of financial infrastructures across countries, and most of the people who have been migrated from the rural regions are still unable to access and use financial products and services offered by the formal financial institutions. Instead, persistent remittances inflows may protect recipient households from financial risks by ensuring them against future income shocks, such as those generated from business cycles, political crisis, natural disasters or other domestic vulnerabilities, thereby causing a decline in savings.

The findings from our empirical study are in contrary to the results of Anzoategui et al.(2013) who use household-level survey data for El Salvador to study the impact of remittances on financial inclusion. They show that remittances promote the use of deposit 
accounts, but they do not have a significant effect on the demand for and use of credits from formal financial institutions. This discrepancy might have arose due to some country-specific features or because of differences in data dimensions. (Theirs data come from a survey of individual households but ours is cross-sectional country level data.)

We have employed only two basic dimensions of financial inclusion in this study and addressed the issue in qualitative terms. But there remains many aspects of financial inclusion where remittances could have played a dynamic role in shaping the behaviors of households and financial institutions. We will take up one of these issues, namely, the impact of remittances on business regulations and entrepreneurial environment in next chapter. The potential avenues for future research with regards to financial inclusion may include the use of more accurate, comprehensive data and flexible econometric tools that could shed light on why and to what extent remittances affect not only the access to and use of deposit and credit instruments, but also of many other financial products and services offered by formal financial institutions that may direct the course of financial inclusion across countries in coming decades. 


\subsection{Bibliography}

1. Abdih, Y., Ralph Chami, Jihad Dagher, and Peter Montiel (2012), Remittances and Institutions: Are Remittances a Curse?, World Development, Vol. 40, pp. 657-666.

2. Acosta, P., Corporacion Andina de Fomento, Pablo Fajnzylber and J. Humberto Lopez, (2007), The Impact of Remittances on Poverty and Human Capital: Evidence from Latin American Household Surveys, World Bank Policy Research Working Paper 4247.

3. Adams, R. H., and John Page (2005), Do International Migration and Remittances Reduce Poverty in Developing Countries?, World Development Vol. 33, No. 10, pp. 16451669.

4. Amuedo-Dorantes, C., Sainz, T. and Pozo, S., (2007)., Remittances and healthcare expenditure patterns of population in origin communities: Evidence from Mexico, INTAL-ITD Working paper 25.

5. Anzoategui, D., Asli Demirguc-Kunt, Maria Soledad Martinez (2013), Remittances and Financial Inclusion: Evidence from El Salvador, World Development, Vol. 54, pp. 338-349.

6. Aggarwal, R., Asli Demirguc-Kunt, and Maria Soledad Martinez Peria (2012), Do remittances promote financial development?, Journal of Development Economics, 96(2), 255-264.

7. Angle, R. F., C. W. J. Granger, John Rice, and Andrew Weiss (1986), Semiparametric estimates of the relation between weather and electricity sales, Journal of the American Statistical Association, 81, 310-320.

8. Batu, M. B., (2010), On the Nonlinearity of Remittances and Economic Growth, University of Guelph, Guelph, Ontario.

9. Beck, T., Asli Demirguc-Kunt, and Maria Soledad Martinez Peria (2005), reaching out: Access to and use of banking services across countries, WPS3754, World Bank Policy Research Working Paper 3754.

10. Building Inclusive Financial Sectors for Development, United Nations, New York. 
11. Cooray, A., (2005) Migrant remittances, financial sector development and the government ownership of banks, School of Economics, University of Wollongong, Australia.

12. Conroy, J. D., (2005) Financial inclusion: A new microfinance initiative for APEC, The Foundation for Development Cooperation, Microfinance Workshop, The APEC Business Advisory Council, Jakarta.

13. Cox-Edwards, A. and Ureta, M., (2003), International migration, remittances, and schooling: Evidence from El Salvador, National Bureau of Economic Research, Working Paper 9766.

14. Demirguc-Kunt, A., and Leora Klapper (2013), Measuring financial inclusion: Explaining variation in use of financial services across and within countries, Brookings paper in economic activity.

15. Dupas, P. and Robinson, J., (2009), Savings constraints and microenterprise development: Evidence from a field Experiment in Kenya, National Bureau of Economic Research Working Paper 14693.

16 Financial Inclusion Data Working Group (FIDWG), Alliance for Financial Inclusion (AFI).

17. Giuliano, P. and Ruiz-Arranz, M., (2009), Remittances, financial development, and growth, Journal of Development Economics 90, 144-152.

18. Gupta, S., Pattillo, C., and Wagh, S., (2009), Effect of remittances on poverty and financial development in Sub-Saharan Africa, World Development 37(1), 104-115.

19. Hardle, W., Hua Liang, Jiti Gao (2000), Partially Linear Models.

20. Koker L. D., and Nicola Jentzsch, (2013), Financial Inclusion and Financial Integrity: Aligned Incentive?, World Development, Vol. 44, pp. 267-280.

21. Kunt, A. D., and Leora Klapper, (2012), Financial Inclusion in Africa, The World Bank. 
22. Li, Q., and Jeffery S. Racine, (2007), Nonparametric Econometrics, Princeton University Press.

23. Racine, J. S., (2008), Nonparametric and Semi-parametric methods in $R$.

24. Rempel, H., and Lobdell, R. A. (1977), The Role of Urabn-Rural Remittances in Rural Development, University of Manitoba.

25. Rapoport, H., and Frederic Docquier, (2004), The Economics of Migrant's Remittances, Stanford Center for International Development, Working Paper No. 236.

26. Robinson, P. M. (1988), Root-N-Consistent Semiparametric Regression, Econometrica, Vol. 56, Issue 4, 931-954.

27. Sarma, M., and Jesim Pais, (2008), Financial Inclusion and Development: A Cross Country Analysis.

28. Stiegler, U., (2013), Migrants' money for financial inclusion? Doctoral Thesis, Department of Political and Social Science, Freie University, Berlin.

29. Toxopeus, H. S., and Robert Lensink (2007), Remittances and Financial Inclusion in Development, Research Paper No. 2007/49, UNU-WIDER.

30. Yang, D. (2005)., International migration, human capital, and entrepreneurship: Evidence from Philippine migrants exchange rate shocks, Mimeo, University of Michigan. 


\subsection{Appendix}

Table 3.1: Description of the indicators of financial inclusion and other explanatory variables, and their data sources.

\begin{tabular}{|c|c|c|}
\hline Variable & Description & Source \\
\hline Indicator & Account at a formal financial institution $(\%$ age $15+)$ & Global Findex, WB \\
\hline Indicator & Account at a formal financial institution, rural $(\%$ age $15+)$ & Global Findex, WB \\
\hline Indicator & Account at a formal financial institution, urban ( $\%$ age $15+)$ & Global Findex, WB \\
\hline Indicator & Saved at a financial institution in the past year $(\%$ age $15+)$ & Global Findex, WB \\
\hline Indicator & Saved at a financial institution in the past year, rural $(\%$ age $15+)$ & Global Findex, WB \\
\hline Indicator & Saved at a financial institution in the past year, urban ( $\%$ age $15+)$ & Global Findex, WB \\
\hline Remit & Personal remittances, received (\% of GDP) & WDI, WB \\
\hline Lgdppc & GDP per capita (constant 2005 US\$) & WDI, WB \\
\hline Legor_UK & Binary variable for British common law & CID \\
\hline Legor_SO & Binary variable for Socialist law & CID \\
\hline Legor_GE & Binary variable for German commercial code & CID \\
\hline Legor_FR & Binary variable for French commercial code & CID \\
\hline Legor_SC & Binary variable for Scandinavian commercial code & CID \\
\hline School_pri & School enrollment, primary ( $\%$ gross $)$ & WDI, WB \\
\hline Pop_ruralp & Rural population (\% of total population) & WDI, WB \\
\hline Tele100 & Telephone lines (per 100 people) & WDI, WB \\
\hline
\end{tabular}


Table 3.2: Semiparametric Partially Linear Model estimates. Dependent Variable is the composite index of financial inclusion, country-level.*

\begin{tabular}{lrrrr}
\hline \hline & Parametric & \multicolumn{3}{r}{ Nonparametric } \\
\hline Variable & & Q1 & Q2 & Q3 \\
\hline Remit & & -0.0092 & -0.0091 & -0.009 \\
Lgdppc & & $(0.0039)$ & $(0.0037)$ & $(0.0037)$ \\
& 0.5493 & & & \\
Legor_UK & $(0.2834)$ & & & \\
& 0.6645 & & & \\
Legor_SO & $(0.2356)$ & & & \\
& -0.0003 & & & \\
Legor_GE & $(0.2356)$ & & & \\
& -0.0038 & & & \\
School_pri & $(0.7746)$ & & & \\
& 0.0076 & & & \\
Pop_ruralp & $(0.0065)$ & & & \\
Tele100 & -0.0042 & & \\
& $(0.0071)$ & & \\
\hline $\mathrm{R}^{2}$ & 0.0114 & & \\
$\mathrm{n}$ & $(0.0094)$ & & \\
\hline \hline
\end{tabular}

Note 1: Standard errors are in parentheses.

Note 2: Q1, Q2, and Q3 represent the nonparametric local linear quartile estimates for remittances.

* The composite index of financial inclusion is computed from the following two indicators of financial inclusion: 1) Account at a formal financial institution, (\% age 15+), and 2) Saved at a financial institution in the past year (\% age $15+)$. 
Table 3.3: Semiparametric Partially Linear Model estimates. Dependent Variable is the index of financial inclusion for account at a formal financial institution, country-level.*

\begin{tabular}{|c|c|c|c|c|}
\hline \multirow{2}{*}{ Variable } & \multirow[t]{2}{*}{ Parametric } & \multicolumn{3}{|c|}{ Nonparametric } \\
\hline & & Q1 & Q2 & Q3 \\
\hline Remit & & $\begin{array}{r}-0.0513 \\
(0.0996)\end{array}$ & $\begin{array}{r}0.0016 \\
(0.0076)\end{array}$ & $\begin{array}{r}0.0587 \\
(0.0776)\end{array}$ \\
\hline Lgdppc & $\begin{array}{r}0.7228 \\
(0.3136)\end{array}$ & & & \\
\hline Legor_UK & $\begin{array}{r}0.6796 \\
(0.2608)\end{array}$ & & & \\
\hline Legor_SO & $\begin{array}{r}0.2489 \\
(0.2607)\end{array}$ & & & \\
\hline Legor_GE & $\begin{array}{r}-0.2520 \\
(0.7746)\end{array}$ & & & \\
\hline School_pri & $\begin{array}{r}0.0171 \\
(0.0071)\end{array}$ & & & \\
\hline Pop_ruralp & $\begin{array}{r}-0.0091 \\
(0.0077)\end{array}$ & & & \\
\hline Tele100 & $\begin{array}{r}0.0175 \\
(0.0104)\end{array}$ & & & \\
\hline $\begin{array}{l}\mathrm{R}^{2} \\
\mathrm{n}\end{array}$ & $\begin{array}{r}0.59 \\
81 \\
\end{array}$ & & & \\
\hline $\begin{array}{l}\text { Note 1: Stanc } \\
\text { Note 2: Q1, } \\
\text { * Index of fin } \\
\text { Account at a }\end{array}$ & $\begin{array}{l}\text { netric local line } \\
\text { the following in } \\
\text { e } 15+) \text {. }\end{array}$ & $\begin{array}{l}\text { quartile est } \\
\text { ator of fina }\end{array}$ & $\begin{array}{l}\text { nates for re } \\
\text { cial inclusic }\end{array}$ & $\begin{array}{l}\text { nittances. } \\
\text { n: }\end{array}$ \\
\hline
\end{tabular}


Table 3.4: Semiparametric Partially Linear Model estimates. Dependent Variable is the index of financial inclusion for saved at a formal financial institution, country-level.*

\begin{tabular}{|c|c|c|c|c|}
\hline & Parametric & \multicolumn{3}{|c|}{ Nonparametric } \\
\hline Variable & & Q1 & $\mathrm{Q} 2$ & Q3 \\
\hline Remit & & $\begin{array}{r}-0.0439 \\
(0.0119)\end{array}$ & $\begin{array}{r}-0.0430 \\
(0.0114)\end{array}$ & $\begin{array}{r}-0.0398 \\
(0.0112)\end{array}$ \\
\hline Lgdppc & $\begin{array}{r}0.5104 \\
(0.3086)\end{array}$ & & & \\
\hline Legor_UK & $\begin{array}{r}0.7247 \\
(0.2566)\end{array}$ & & & \\
\hline Legor_SO & $\begin{array}{r}-0.1392 \\
(0.2566)\end{array}$ & & & \\
\hline Legor_GE & $\begin{array}{r}0.1615 \\
(0.8437)\end{array}$ & & & \\
\hline School_pri & $\begin{array}{r}0.0053 \\
(0.0070)\end{array}$ & & & \\
\hline Pop_ruralp & $\begin{array}{r}-0.0016 \\
(0.0076)\end{array}$ & & & \\
\hline Tele100 & $\begin{array}{r}0.0085 \\
(0.0103)\end{array}$ & & & \\
\hline $\mathrm{R}^{2}$ & 0.54 & & & \\
\hline $\mathrm{n}$ & 81 & & & \\
\hline $\begin{array}{l}\text { Note 1: Stan } \\
\text { Note 2: Q1, } \\
\text { * Index of fin } \\
\text { Saved at a fin }\end{array}$ & $\begin{array}{l}\text { netric local lin } \\
\text { the following i } \\
\text { (\% age } 15+\text { ). }\end{array}$ & $\begin{array}{l}\text { quartile est } \\
\text { ator of fina }\end{array}$ & $\begin{array}{l}\text { mates for re } \\
\text { cial inclusi }\end{array}$ & $\begin{array}{l}\text { nittances. } \\
\text { n: }\end{array}$ \\
\hline
\end{tabular}


Table 3.5: Semiparametric Partially Linear Model estimates. Dependent Variable is the composite index of financial inclusion, rural-sector.*

\begin{tabular}{lrrrr}
\hline \hline & Parametric & \multicolumn{3}{c}{ Nonparametric } \\
\hline Variable & & Q1 & Q2 & Q3 \\
\hline Remit & & -0.0095 & -0.0093 & -0.0092 \\
& & $(0.0039)$ & $(0.0038)$ & $(0.0037)$ \\
Lgdppc & 0.5806 & & & \\
Legor_UK & $(0.2928)$ & & & \\
& 0.7095 & & & \\
Legor_SO & $(0.2435)$ & & & \\
& -0.0494 & & & \\
Legor_GE & $(0.2435)$ & & & \\
& -0.1766 & & & \\
School_pri & $(0.8006)$ & & & \\
Pop_ruralp & 0.0083 & & & \\
Tele100 & $(0.0066)$ & & & \\
& -0.0028 & & & \\
\hline $\mathrm{R}^{2}$ & $(0.0072)$ & & & \\
$\mathrm{n}$ & 0.0118 & & & \\
\hline \hline
\end{tabular}

Note 1: Standard errors are in parentheses.

Note 2: Q1, Q2, and Q3 represent the nonparametric local linear quartile estimates for remittances.

* The composite index of financial inclusion is computed from the following two indicators of financial inclusion: 1) Account at a formal financial institution, rural (\% age 15+), and 2) Saved at a financial institution in the past year, rural (\% age $15+)$. 
Table 3.6: Semiparametric Partially Linear Model estimates. Dependent Variable is the index of financial inclusion for account at a formal financial institution, rural-sector.*

\begin{tabular}{|c|c|c|c|c|}
\hline \multirow[b]{2}{*}{ Variable } & \multirow[t]{2}{*}{ Parametric } & \multicolumn{3}{|c|}{ Nonparametric } \\
\hline & & Q1 & $\mathrm{Q} 2$ & Q3 \\
\hline Remit & & $\begin{array}{r}-0.0091 \\
(0.0014)\end{array}$ & $\begin{array}{r}-0.0087 \\
(0.0015)\end{array}$ & $\begin{array}{r}-0.0086 \\
(0.0015)\end{array}$ \\
\hline Lgdppc & $\begin{array}{r}0.8070 \\
(0.3240)\end{array}$ & & & \\
\hline Legor_UK & $\begin{array}{r}0.6989 \\
(0.2695)\end{array}$ & & & \\
\hline Legor_SO & $\begin{array}{r}0.2746 \\
(0.2694)\end{array}$ & & & \\
\hline Legor_GE & $\begin{array}{r}-0.1514 \\
(0.8858)\end{array}$ & & & \\
\hline School_pri & $\begin{array}{r}0.0179 \\
(0.0074)\end{array}$ & & & \\
\hline Pop_ruralp & $\begin{array}{r}-0.0059 \\
(0.0080)\end{array}$ & & & \\
\hline Tele100 & $\begin{array}{r}0.0179 \\
(0.0108)\end{array}$ & & & \\
\hline $\begin{array}{l}\mathrm{R}^{2} \\
\mathrm{n}\end{array}$ & $\begin{array}{r}0.58 \\
81\end{array}$ & & & \\
\hline $\begin{array}{l}\text { Note 1: Stan } \\
\text { Note 2: Q1, } \\
\text { * Index of fin } \\
\text { Account at a }\end{array}$ & $\begin{array}{l}\text { netric local line } \\
\text { the following in } \\
\text { ar, rural } \% \text { ag }\end{array}$ & $\begin{array}{l}\text { quartile est } \\
\text { ator of fina } \\
5+) \text {. }\end{array}$ & $\begin{array}{l}\text { mates for re } \\
\text { cial inclusi }\end{array}$ & $\begin{array}{l}\text { nittances. } \\
\text { n: }\end{array}$ \\
\hline
\end{tabular}


Table 3.7: Semiparametric Partially Linear Model estimates. Dependent Variable is the index of financial inclusion for saved at a formal financial institution, rural-sector.*

\begin{tabular}{|c|c|c|c|c|}
\hline \multirow[b]{2}{*}{ Variable } & \multirow[t]{2}{*}{ Parametric } & \multicolumn{3}{|c|}{ Nonparametric } \\
\hline & & Q1 & Q2 & Q3 \\
\hline Remit & & $\begin{array}{r}-0.0370 \\
(0.0096)\end{array}$ & $\begin{array}{r}-0.0358 \\
(0.0093)\end{array}$ & $\begin{array}{r}-0.0308 \\
(0.0092)\end{array}$ \\
\hline Lgdppc & $\begin{array}{r}0.5617 \\
(0.3214)\end{array}$ & & & \\
\hline Legor_UK & $\begin{array}{r}0.8201 \\
(0.2673)\end{array}$ & & & \\
\hline Legor_SO & $\begin{array}{r}-0.1072 \\
(0.2673)\end{array}$ & & & \\
\hline Legor_GE & $\begin{array}{r}0.0905 \\
(0.8787)\end{array}$ & & & \\
\hline School_pri & $\begin{array}{r}0.0059 \\
(0.0073)\end{array}$ & & & \\
\hline Pop_ruralp & $\begin{array}{r}-0.0008 \\
(0.0079)\end{array}$ & & & \\
\hline Tele100 & $\begin{array}{r}0.0072 \\
(0.0107)\end{array}$ & & & \\
\hline $\mathrm{R}^{2}$ & 0.51 & & & \\
\hline $\mathrm{n}$ & 81 & & & \\
\hline $\begin{array}{l}\text { Note 1: Stanc } \\
\text { Note 2: Q1, } \\
\text { * Index of fin } \\
\text { Saved at a fin }\end{array}$ & $\begin{array}{l}\text { metric local lin } \\
\text { the following in } \\
\text {, rural }(\% \text { age }\end{array}$ & $\begin{array}{l}\text { quartile est } \\
\text { ator of fina }\end{array}$ & $\begin{array}{l}\text { mates for } \mathrm{r} \\
\text { cial inclusi }\end{array}$ & $\begin{array}{l}\text { nittances. } \\
\text { n: }\end{array}$ \\
\hline
\end{tabular}


Table 3.8: Semiparametric Partially Linear Model estimates. Dependent Variable is the composite index of financial inclusion, urban-sector.*

\begin{tabular}{lrrrr}
\hline \hline & Parametric & \multicolumn{3}{r}{ Nonparametric } \\
\hline Variable & & Q1 & Q2 & Q3 \\
\hline Remit & & -0.0371 & -0.0265 & 0.0118 \\
Lgdppc & & $(0.0645)$ & $(0.0533)$ & $(0.0752)$ \\
& 0.4437 & & & \\
Legor_UK & $(0.2843)$ & & & \\
& 0.6115 & & & \\
Legor_SO & $(0.2364)$ & & & \\
& -0.0419 & & & \\
Legor_GE & $(0.2364)$ & & & \\
& -0.0134 & & & \\
School_pri & $(0.7772)$ & & & \\
Pop_ruralp & 0.0070 & & & \\
& $(0.0065)$ & & & \\
Tele100 & -0.0070 & & & \\
& $(0.0071)$ & & \\
\hline $\mathrm{R}^{2}$ & 0.0140 & & \\
$\mathrm{n}$ & $(0.0095)$ & & \\
\hline \hline
\end{tabular}

Note 1: Standard errors are in parentheses.

Note 2: Q1, Q2, and Q3 represent the nonparametric local linear quartile estimates for remittances.

* The composite index of financial inclusion is computed from the following two indicators of financial inclusion: 1) Account at a formal financial institution, urban (\% age 15+), and 2) Saved at a financial institution in the past year, urban (\% age $15+$ ). 
Table 3.9: Semiparametric Partially Linear Model estimates. Dependent Variable is the index of financial inclusion for account at a formal financial institution, urban-sector.*

\begin{tabular}{|c|c|c|c|c|}
\hline & Parametric & \multicolumn{3}{|c|}{ Nonparametric } \\
\hline Variable & & Q1 & Q2 & Q3 \\
\hline Remit & & $\begin{array}{r}0.0231 \\
(0.0566)\end{array}$ & $\begin{array}{r}0.0384 \\
(0.0660)\end{array}$ & $\begin{array}{r}0.0481 \\
(0.0911)\end{array}$ \\
\hline Lgdppc & $\begin{array}{r}0.5749 \\
(0.2786)\end{array}$ & & & \\
\hline Legor_UK & $\begin{array}{r}0.5817 \\
(0.2317)\end{array}$ & & & \\
\hline Legor_SO & $\begin{array}{r}0.1153 \\
(0.2316)\end{array}$ & & & \\
\hline Legor_GE & $\begin{array}{r}-0.2581 \\
(0.7616)\end{array}$ & & & \\
\hline School_pri & $\begin{array}{r}0.0086 \\
(0.0064)\end{array}$ & & & \\
\hline Pop_ruralp & $\begin{array}{r}-0.0001 \\
(0.0067)\end{array}$ & & & \\
\hline Tele100 & $\begin{array}{r}0.0241 \\
(0.0093)\end{array}$ & & & \\
\hline $\mathrm{R}^{2}$ & 0.58 & & & \\
\hline $\mathrm{n}$ & 81 & & & \\
\hline
\end{tabular}

Note 1: Standard errors are in parentheses.

Note 2: Q1, Q2, and Q3 represent the nonparametric local linear quartile estimates for remittances.

* Index of financial inclusion is computed from the following indicator of financial inclusion:

Account at a financial institution in the past year, urban (\% age $15+)$. 
Table 3.10: Semiparametric Partially Linear Model estimates. Dependent Variable is the index of financial inclusion for saved at a formal financial institution, urban-sector.*

\begin{tabular}{|c|c|c|c|c|}
\hline & Parametric & \multicolumn{3}{|c|}{ Nonparametric } \\
\hline Variable & & Q1 & Q2 & Q3 \\
\hline Remit & & $\begin{array}{r}-0.0206 \\
(0.0194)\end{array}$ & $\begin{array}{r}-0.0169 \\
(0.0193)\end{array}$ & $\begin{array}{c}-0.0144 \\
(0.0200)\end{array}$ \\
\hline Lgdppc & $\begin{array}{r}0.4412 \\
(0.3807)\end{array}$ & & & \\
\hline Legor_UK & $\begin{array}{r}0.5353 \\
(0.2891)\end{array}$ & & & \\
\hline Legor_SO & $\begin{array}{r}-0.3137 \\
(0.2884)\end{array}$ & & & \\
\hline Legor_GE & $\begin{array}{r}0.0871 \\
(1.0160)\end{array}$ & & & \\
\hline School_pri & $\begin{array}{r}0.0073 \\
(0.0083)\end{array}$ & & & \\
\hline Pop_ruralp & $\begin{array}{r}0.0009 \\
(0.0085)\end{array}$ & & & \\
\hline Tele100 & $\begin{array}{r}0.0094 \\
(0.0123)\end{array}$ & & & \\
\hline $\mathrm{R}^{2}$ & 0.32 & & & \\
\hline $\mathrm{n}$ & 81 & & & \\
\hline $\begin{array}{l}\text { Note 1: Stan } \\
\text { Note 2: Q1, } \\
\text { * Index of fin } \\
\text { Saved at a fil }\end{array}$ & $\begin{array}{l}\text { netric local lin } \\
\text { the following i } \\
\text { urban }(\% \text { age }\end{array}$ & $\begin{array}{l}\text { quartile est } \\
\text { ator of fina } \\
\text { ). }\end{array}$ & $\begin{array}{l}\text { mates for re } \\
\text { cial inclusi }\end{array}$ & nittances. \\
\hline
\end{tabular}


Table 3.11: Remittances and financial inclusion: OLS estimates from linear parametric models (country-level).

\begin{tabular}{|c|c|c|c|}
\hline \multirow[b]{2}{*}{ Variable } & \multicolumn{3}{|c|}{ Dependent variable: The index of financial inclusion at country-level ${ }^{\star}$} \\
\hline & Model-I & Model-II & Model-III \\
\hline Remit & $\begin{array}{l}-0.0129 \\
(-1.213)\end{array}$ & $\begin{array}{l}-0.0082 \\
(-0.705)\end{array}$ & $\begin{array}{r}-0.0342^{* * *} \\
(-2.723)\end{array}$ \\
\hline Lgdppc & $\begin{array}{r}0.6542^{* *} \\
(2.294)\end{array}$ & $\begin{array}{r}0.8885^{* * *} \\
(2.848)\end{array}$ & $\begin{array}{r}0.5634^{*} \\
(1.67)\end{array}$ \\
\hline Legor_UK & $\begin{array}{r}0.6252^{* * *} \\
(2.865)\end{array}$ & $\begin{array}{r}0.6459^{* * *} \\
(2.75)\end{array}$ & $\begin{array}{r}0.7021^{* * *} \\
(2.753)\end{array}$ \\
\hline Legor_SO & $\begin{array}{r}0.1268 \\
(-0.588)\end{array}$ & $\begin{array}{r}0.1067 \\
(0.453)\end{array}$ & $\begin{array}{l}-0.3463 \\
(-1.353)\end{array}$ \\
\hline Legor_GE & $\begin{array}{l}-0.0981 \\
(-0.126)\end{array}$ & $\begin{array}{r}-0.3421 \\
(0.6895)\end{array}$ & $\begin{array}{c}0.0241 \\
(0.026)\end{array}$ \\
\hline School_pri & $\begin{array}{r}0.0096 \\
(1.51)\end{array}$ & $\begin{array}{r}0.0192^{* * *} \\
(2.746)\end{array}$ & $\begin{array}{c}0.0094 \\
(1.236)\end{array}$ \\
\hline Pop_ruralp & $\begin{array}{l}-0.0017 \\
(-0.267)\end{array}$ & $\begin{array}{r}-0.0039 \\
(-0.54)\end{array}$ & $\begin{array}{c}-0.0016 \\
(-0.207)\end{array}$ \\
\hline Tele100 & $\begin{array}{r}0.0135 \\
(1.433)\end{array}$ & $\begin{array}{r}0.0206^{* *} \\
(2.002)\end{array}$ & $\begin{array}{r}0.011 \\
(0.984)\end{array}$ \\
\hline Constant & $\begin{array}{r}-3.8289^{* * *} \\
(-3.046)\end{array}$ & $\begin{array}{r}-5.539^{* * *} \\
(-4.029)\end{array}$ & $\begin{array}{r}-3.533^{* *} \\
(-2.366)\end{array}$ \\
\hline Observations & 81 & 81 & 81 \\
\hline $\mathrm{R}^{2}$ & 0.497 & 0.604 & 0.452 \\
\hline
\end{tabular}

Note 1: t-statistics are in parentheses.

Note 2. Significance levels denoted as ${ }^{* * *} \mathrm{p}<0.01,{ }^{* *} \mathrm{p}<0.05,{ }^{*} \mathrm{p}<0.10$.

$\star$ Dependent variable for Model I is the composite index (computed from indicators in models II and III) of financial inclusion at country-level; for Model II, it is the computed index of financial inclusion for indicator- account at a formal financial institution ( $\%$ age $15+$ ); and for Model III, it is the computed index of financial inclusion for indicator- saved at a formal financial institution $(\%$ age $15+)$. 
Table 3.12: Remittances and financial inclusion: OLS estimates from linear parametric models (rural-sector).

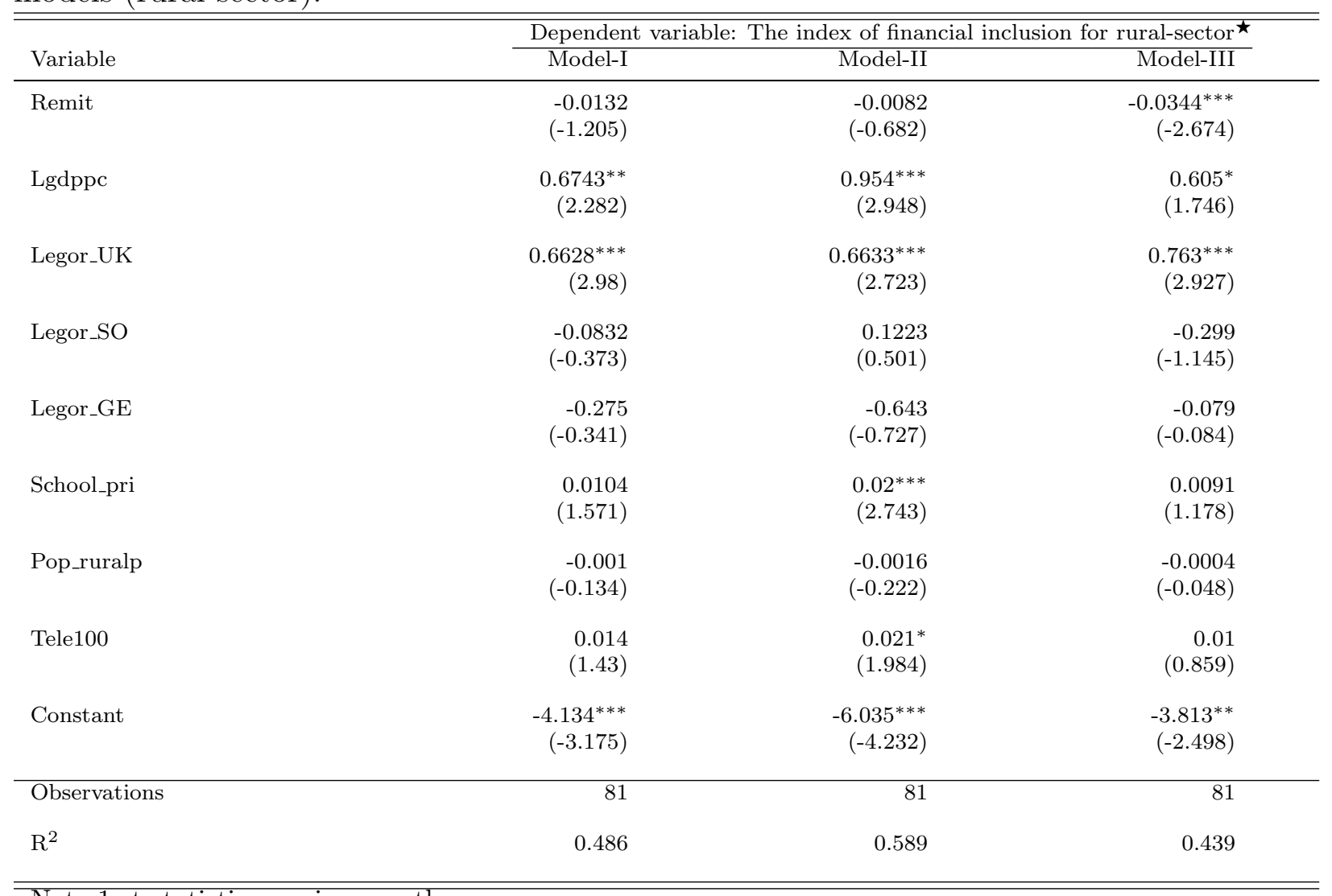

Note 1: t-statistics are in parentheses.

Note 2. Significance levels denoted as ${ }^{* * *} \mathrm{p}<0.01,{ }^{* *} \mathrm{p}<0.05,{ }^{*} \mathrm{p}<0.10$.

$\star$ Dependent variable for Model I is the composite index (computed from indicators in models II and III) of financial inclusion at rural-sector; for Model II, it is the computed index of financial inclusion for indicator- account at a formal financial institution, rural ( $\%$ age $15+)$; and for Model III, it is the computed index of financial inclusion for indicator- saved at a formal financial institution, rural $(\%$ age $15+)$. 
Table 3.13: Remittances and financial inclusion: OLS estimates from linear parametric models (urban-sector).

\begin{tabular}{|c|c|c|c|}
\hline \multirow[b]{2}{*}{ Variable } & \multicolumn{3}{|c|}{ Dependent variable: The index of financial inclusion for urban-sector ${ }^{\star}$} \\
\hline & Model-I & Model-II & Model-III \\
\hline Remit & $\begin{array}{l}-0.0106 \\
(-0.995)\end{array}$ & $\begin{array}{l}-0.0132 \\
(-1.271)\end{array}$ & $\begin{array}{l}-0.0071 \\
(-0.503)\end{array}$ \\
\hline Lgdppc & $\begin{array}{r}0.579^{* *} \\
(2.018)\end{array}$ & $\begin{array}{r}0.719^{* *} \\
(2.577)\end{array}$ & $\begin{array}{c}0.5452 \\
(1.431)\end{array}$ \\
\hline Legor_UK & $\begin{array}{r}0.540^{* *} \\
(2.501)\end{array}$ & $\begin{array}{r}0.524^{* *} \\
(2.494)\end{array}$ & $\begin{array}{r}0.5454^{*} \\
(1.902)\end{array}$ \\
\hline Legor_SO & $\begin{array}{r}-0.172 \\
(-0.794)\end{array}$ & $\begin{array}{c}0.0164 \\
(0.078)\end{array}$ & $\begin{array}{r}-0.5007^{*} \\
(-1.74)\end{array}$ \\
\hline Legor_GE & $\begin{array}{r}-0.111 \\
(-0.142)\end{array}$ & $\begin{array}{r}-0.345 \\
(-0.453)\end{array}$ & $\begin{array}{l}-0.042 \\
(-0.04)\end{array}$ \\
\hline School_pri & $\begin{array}{r}0.01 \\
(1.54)\end{array}$ & $\begin{array}{c}0.011^{*} \\
(1.796)\end{array}$ & $\begin{array}{r}0.012 \\
(1.39)\end{array}$ \\
\hline Pop_ruralp & $\begin{array}{r}0.0023 \\
(0.354)\end{array}$ & $\begin{array}{r}0.004 \\
(0.638)\end{array}$ & $\begin{array}{c}0.0025 \\
(0.295)\end{array}$ \\
\hline Tele100 & $\begin{array}{c}0.016^{*} \\
(1.713)\end{array}$ & $\begin{array}{r}0.026^{* * *} \\
(2.868)\end{array}$ & $\begin{array}{r}0.015 \\
(1.18)\end{array}$ \\
\hline Constant & $\begin{array}{r}-3.683^{* * *} \\
(-2.914)\end{array}$ & $\begin{array}{r}-4.368^{* * *} \\
(-3.553)\end{array}$ & $\begin{array}{r}-3.895^{* *} \\
(-2.32)\end{array}$ \\
\hline Observations & 81 & 81 & 81 \\
\hline $\mathrm{R}^{2}$ & 0.431 & 0.581 & 0.295 \\
\hline
\end{tabular}

Note 1: t-statistics are in parentheses.

Note 2. Significance levels denoted as ${ }^{* * *} \mathrm{p}<0.01,{ }^{* *} \mathrm{p}<0.05,{ }^{*} \mathrm{p}<0.10$.

$\star$ Dependent variable for Model I is the composite index (computed from indicators in models II and III) of financial inclusion at urban-sector; for Model II, it is the computed index of financial inclusion for indicator- account at a formal financial institution, urban (\% age 15+); and for Model III, it is the computed index of financial inclusion for indicator- saved at a formal financial institution, urban (\% age $15+)$. 
Table 3.14: Remittances (in first-differences) and financial inclusion: OLS estimates from linear parametric models (country-level).

\begin{tabular}{|c|c|c|c|}
\hline \multirow[b]{2}{*}{ Variable } & \multicolumn{3}{|c|}{ Dependent variable: The index of financial inclusion at country-level ${ }^{\star}$} \\
\hline & Model-I & Model-II & Model-III \\
\hline $\mathrm{d}($ Remit $)$ & $\begin{array}{r}-0.0189^{* * *} \\
(-2.7315)\end{array}$ & $\begin{array}{l}-0.0150^{*} \\
(-1.9549)\end{array}$ & $\begin{array}{r}-0.0324^{* * *} \\
(-3.9701)\end{array}$ \\
\hline Lgdppc & $\begin{array}{r}0.7035^{* *} \\
(2.6349)\end{array}$ & $\begin{array}{r}0.9165^{* * *} \\
(3.0993)\end{array}$ & $\begin{array}{r}0.7315^{* *} \\
(2.3322)\end{array}$ \\
\hline Legor_UK & $\begin{array}{r}0.4564^{* *} \\
(2.1352)\end{array}$ & $\begin{array}{r}0.5424^{* *} \\
(2.2911)\end{array}$ & $\begin{array}{r}0.3948 \\
(1.5724)\end{array}$ \\
\hline Legor_SO & $\begin{array}{r}-0.1742 \\
(-0.8457)\end{array}$ & $\begin{array}{r}0.0930 \\
(0.4076)\end{array}$ & $\begin{array}{c}-0.4803^{*} \\
(-1.9849)\end{array}$ \\
\hline Legor_GE & $\begin{array}{r}-0.0644 \\
(-0.0854)\end{array}$ & $\begin{array}{r}-0.3043 \\
(-0.3645)\end{array}$ & $\begin{array}{r}0.0531 \\
(0.0599)\end{array}$ \\
\hline School_pri & $\begin{array}{r}0.0081 \\
(1.3117)\end{array}$ & $\begin{array}{r}0.0184^{* * *} \\
(2.6611)\end{array}$ & $\begin{array}{r}0.0075 \\
(1.0272)\end{array}$ \\
\hline Pop_ruralp & $\begin{array}{r}0.0006 \\
(0.1078)\end{array}$ & $\begin{array}{r}-0.0025 \\
(-0.3569)\end{array}$ & $\begin{array}{r}0.0030 \\
(0.4090)\end{array}$ \\
\hline Tele100 & $\begin{array}{r}0.0135 \\
(1.4835)\end{array}$ & $\begin{array}{r}0.0204^{* *} \\
(2.0312)\end{array}$ & $\begin{array}{r}0.0108 \\
(1.0116)\end{array}$ \\
\hline Constant & $\begin{array}{r}-3.9707^{* * *} \\
(-3.3925)\end{array}$ & $\begin{array}{r}-5.6337^{* * *} \\
(-4.3456)\end{array}$ & $\begin{array}{r}-4.1818^{* * *} \\
(-3.0410)\end{array}$ \\
\hline Observations & 80 & 80 & 80 \\
\hline Adjusted $\mathrm{R}^{2}$ & 0.479 & 0.581 & 0.447 \\
\hline
\end{tabular}

Note 1: t-statistics are in parentheses.

Note 2. Significance levels denoted as ${ }^{* * *} \mathrm{p}<0.01,{ }^{* *} \mathrm{p}<0.05,{ }^{*} \mathrm{p}<0.10$.

$\star$ Dependent variable for Model I is the composite index (computed from indicators in models II and III) of financial inclusion at country-level; for Model II, it is the computed index of financial inclusion for indicator- account at a formal financial institution (\% age 15+); and for Model III, it is the computed index of financial inclusion for indicator- saved at a formal financial institution (\% age $15+)$. 
Table 3.15: Remittances (in first-differences) and financial inclusion: OLS estimates from linear parametric models (rural-sector).

\begin{tabular}{|c|c|c|c|}
\hline \multirow[b]{2}{*}{ Variable } & \multicolumn{3}{|c|}{ Dependent variable: The index of financial inclusion for rural-sector ${ }^{\star}$} \\
\hline & Model-I & Model-II & Model-III \\
\hline $\mathrm{d}($ Remit $)$ & $\begin{array}{r}-0.0195^{* * *} \\
(-2.7170)\end{array}$ & $\begin{array}{l}-0.0155^{*} \\
(-1.9453)\end{array}$ & $\begin{array}{r}-0.0332^{* * *} \\
(-3.9871)\end{array}$ \\
\hline Lgdppc & $\begin{array}{r}0.7240^{* *} \\
(2.6145)\end{array}$ & $\begin{array}{r}0.9804^{* * *} \\
(3.1902)\end{array}$ & $\begin{array}{r}0.7701^{* *} \\
(2.4065)\end{array}$ \\
\hline Legor_UK & $\begin{array}{r}0.4927^{* *} \\
(2.2226)\end{array}$ & $\begin{array}{c}0.5516^{* *} \\
(2.2422)\end{array}$ & $\begin{array}{c}0.4374^{*} \\
(1.7074)\end{array}$ \\
\hline Legor_SO & $\begin{array}{r}-0.1378 \\
(-0.6452)\end{array}$ & $\begin{array}{r}0.1042 \\
(0.4398)\end{array}$ & $\begin{array}{c}-0.4460^{*} \\
(-1.8066)\end{array}$ \\
\hline Legor_GE & $\begin{array}{r}-0.2426 \\
(-0.3104)\end{array}$ & $\begin{array}{r}-0.6053 \\
(-0.6978)\end{array}$ & $\begin{array}{r}-0.0530 \\
(-0.0587)\end{array}$ \\
\hline School_pri & $\begin{array}{r}0.0087 \\
(1.3446)\end{array}$ & $\begin{array}{r}0.0188^{* *} \\
(2.6287)\end{array}$ & $\begin{array}{r}0.0068 \\
(0.9126)\end{array}$ \\
\hline Pop_ruralp & $\begin{array}{r}0.0017 \\
(0.2705)\end{array}$ & $\begin{array}{r}-0.0001 \\
(-0.0162)\end{array}$ & $\begin{array}{r}0.0048 \\
(0.6251)\end{array}$ \\
\hline Tele100 & $\begin{array}{r}0.0140 \\
(1.4866)\end{array}$ & $\begin{array}{c}0.0207^{*} \\
(1.9775)\end{array}$ & $\begin{array}{r}0.0097 \\
(0.8968)\end{array}$ \\
\hline Constant & $\begin{array}{r}-4.2612^{* * *} \\
(-3.5100)\end{array}$ & $\begin{array}{r}-6.1083^{* * *} \\
(-4.5339)\end{array}$ & $\begin{array}{r}-4.4167^{* * *} \\
(-3.1480)\end{array}$ \\
\hline Observations & 81 & 81 & 81 \\
\hline Adjusted $\mathrm{R}^{2}$ & 0.465 & 0.562 & 0.433 \\
\hline
\end{tabular}

Note 1: t-statistics are in parentheses.

Note 2. Significance levels denoted as ${ }^{* * *} \mathrm{p}<0.01,{ }^{* *} \mathrm{p}<0.05,{ }^{*} \mathrm{p}<0.10$.

$\star$ Dependent variable for Model I is the composite index (computed from indicators in models II and III) of financial inclusion at rural-sector; for Model II, it is the computed index of financial inclusion for indicator- account at a formal financial institution, rural (\% age 15+); and for Model III, it is the computed index of financial inclusion for indicator- saved at a formal financial institution, rural (\% age $15+$ ). 
Table 3.16: Remittances (in first-differences) and financial inclusion: OLS estimates from linear parametric models (urban-sector).

\begin{tabular}{|c|c|c|c|}
\hline \multirow[b]{2}{*}{ Variable } & \multicolumn{3}{|c|}{ Dependent variable: The index of financial inclusion for urban-sector ${ }^{\star}$} \\
\hline & Model-I & Model-II & Model-III \\
\hline $\mathrm{d}($ Remit $)$ & $\begin{array}{r}-0.0175^{* *} \\
(-2.5156)\end{array}$ & $\begin{array}{r}-0.0180^{* * *} \\
(-2.6558)\end{array}$ & $\begin{array}{r}-0.0198^{* *} \\
(-2.1169)\end{array}$ \\
\hline Lgdppc & $\begin{array}{r}0.6174^{* *} \\
(2.2987)\end{array}$ & $\begin{array}{r}0.7753^{* * *} \\
(2.9767)\end{array}$ & $\begin{array}{r}0.5551 \\
(1.5424)\end{array}$ \\
\hline Legor_UK & $\begin{array}{c}0.4081^{*} \\
(1.8979)\end{array}$ & $\begin{array}{c}0.3877^{*} \\
(1.8593)\end{array}$ & $\begin{array}{r}0.4060 \\
(1.4092)\end{array}$ \\
\hline Legor_SO & $\begin{array}{r}-0.1998 \\
(-0.9641)\end{array}$ & $\begin{array}{r}-0.0168 \\
(-0.0836)\end{array}$ & $\begin{array}{l}-0.5157^{*} \\
(-1.8575)\end{array}$ \\
\hline Legor_GE & $\begin{array}{r}-0.0723 \\
(-0.0954)\end{array}$ & $\begin{array}{r}-0.3089 \\
(-0.4202)\end{array}$ & $\begin{array}{r}0.0111 \\
(0.0109)\end{array}$ \\
\hline School_pri & $\begin{array}{r}0.0088 \\
(1.4039)\end{array}$ & $\begin{array}{c}0.0104^{*} \\
(1.7078)\end{array}$ & $\begin{array}{r}0.0102 \\
(1.2168)\end{array}$ \\
\hline Pop_ruralp & $\begin{array}{r}0.0041 \\
(0.6450)\end{array}$ & $\begin{array}{r}0.0058 \\
(0.9397)\end{array}$ & $\begin{array}{r}0.0045 \\
(0.5304)\end{array}$ \\
\hline Tele100 & $\begin{array}{c}0.0161^{*} \\
(1.7605)\end{array}$ & $\begin{array}{r}0.0262^{* * *} \\
(2.9515)\end{array}$ & $\begin{array}{r}0.0148 \\
(1.212)\end{array}$ \\
\hline Constant & $\begin{array}{r}-3.8053^{* * *} \\
(-3.2315)\end{array}$ & $\begin{array}{r}-4.5861^{* * *} \\
(-4.0163)\end{array}$ & $\begin{array}{r}-3.8583^{* *} \\
(-2.4455)\end{array}$ \\
\hline Observations & 80 & 80 & 80 \\
\hline Adjusted $\mathrm{R}^{2}$ & 0.415 & 0.571 & 0.263 \\
\hline
\end{tabular}

Note 1: t-statistics are in parentheses.

Note 2. Significance levels denoted as ${ }^{* * *} \mathrm{p}<0.01,{ }^{* *} \mathrm{p}<0.05,{ }^{*} \mathrm{p}<0.10$.

$\star$ Dependent variable for Model I is the composite index (computed from indicators in models II and III) of financial inclusion at urban-sector; for Model II, it is the computed index of financial inclusion for indicator- account at a formal financial institution, urban (\% age 15+); and for Model III, it is the computed index of financial inclusion for indicator- saved at a formal financial institution, urban (\% age $15+$ ). 


\section{Chapter 4}

\section{Do Remittances Enhance the Ease of}

\section{Starting a Business?*}

\subsection{Introduction}

There is a growing body of literature that documents a positive linkage between remittances and entrepreneurship in the recipient countries. Receipts from remittances are likely to influence a potential entrepreneur's decision to start a business. Empirical research on remittances find the evidence that remittances are used to finance start-up and operating costs for local businesses. As a source of international capital, remittances are found to promote business ownership and increase investment in new businesses. Some case studies indicate that the inflow of remittances can lead to a significantly higher level of investment in existing microenterprises.

Despite the relevance of remittances in shaping entrepreneurial activities in recipient countries, the literature on remittances has paid no attention to the link between these financial transfers and the ease of starting a business. The term 'red tape' is commonly used

${ }^{*}$ I would like to thank my advisor, Prof. Feng Yao, for his guidance throughout this research work. I am thankful to Prof. Stratford Douglas, Prof. Arabinda Basistha, Prof. Andrew Young, and Prof. Philip Michelbach for their constructive comments and suggestions. All remaining errors are mine. 
in business arena to refer to an excessive bureaucracy or adherence to rules and formalities, especially in public business. For 2014, for instance, the time required to start a business in the U. S. is six days. This is longer than in Canada and France, along with eight other countries, where it takes five days. This signifies the fact that red tape plays a critical role to hold back small businesses and entrepreneurs within an economy.

Canare et al. (2015) argue that the easier it is to establish and run a business, the more investors will be encouraged to invest, and thus more employment is generated. They assert that a good business environment also promotes competition and encourages innovation and expansion. To the best of our knowledge, there is no study that exclusively examines the relationship between remittances and the institutional framework that affects entrepreneurship. Mundaca (2008) opines that much work remains to be done in analyzing the economic effects of remittances and their interaction with business and financial sectors. Our goal is to bridge this gap by considering the effects of remittances within a framework of financial institutions and business regulations that deals with small and medium-sized businesses. This idea is consistent with the study of causality between remittances and institutional quality that has recently been highlighted in the remittances literature.

For an entrepreneur to start up and formally operate a business, several official procedures are commonly required in practice. This process also involves considerable amount of time, costs associated with such procedures as verifications, pre- and post-registrations, licenses, permits, and inscriptions for the company and employees with relevant authorities, and a stipulated amount of capital (Doing Business, WB, 2015). A potential entrepreneur, therefore, is confronted with such legal, procedural, and regulatory requirements before starting a business. In the business literature, such an environment is uniquely identified in terms of a measure called 'starting a business.'

The 'starting a business' is a measure of business regulations and entrepreneurial performance in a country. This variable is numerically expressed in terms of what is called 'distance to frontier' score. (Henceforth, DTF score.) A measure of DTF score indicates an 
absolute quality or level of performance of an economy with regards to the ease of starting a business. The higher is the DTF score, the better is the performance of an economy with respect to starting a business. A higher DTF score implies a smaller gap for an economy relative to the best performance, known as the 'frontier.' The starting a business indicator, measured as DTF score, is the response variable in this essay.

Note that starting a business variable expressed as DTF score is not the same as that of the ease of doing business. A drawback of the ease of doing business ranking is that it can measure the regulatory performance of economies only relative to the performance of others. It does not provide information on how the absolute quality of the regulatory environment is improving over time. Nor does it provide information on how large the gaps are between economies at a single point of time. The DTF score measure is designed to address both of these shortcomings. The DTF score illustrates the distance of an economy to the frontier, and the change in the measure over time shows the extent to which the economy has closed this gap. The frontier is a score derived from the most efficient practice or highest score achieved on all set of indicators in the doing business framework. The DTF score measure benchmarks economies to the frontier in regulatory practice, measuring the absolute distance to the best performance on each indicator (Doing Business, WB, 2014).

The DTF score representing the starting a business variable, as described above, is composed of indicators including officially required procedures that involve substantial amount of time and costs. The company law or commercial code of a country mandates a potential entrepreneur to comply with these and other legal and regulatory requirements to formally set up and run a business. However, such legal procedures are not rigid in the context of many developing countries. The process of monitoring and functioning of financial institutions are driven much by either narrow political interests or external monetary and financial shocks.

Grabel (2008) opines that formal financial institutions in many countries, either lowor high-income countries, have turned their limited attention away from small businesses 
and toward speculative activities in the era of financial liberalization. In the context of rising remittances inflows, however, efforts to capture the booming remittances market may cause formal financial institutions to respond to their smaller customers and local businesses by simplifying their legal means and procedures. This, in effect, urges the nation's legal authorities to ease burdensome regulatory practices and bureaucratic procedures so as to ensure a greater participation in the formal financial sector. Recently, the initiatives taken by many governments, international organizations, and banks to increase 'financial inclusion' of their population are key examples of such inclusive policy reforms.

Since 2006, the World Bank has been ranking almost 200 countries in terms of their business environment and the 'ease of doing business' in these economies. The rationale behind this is the importance of a thriving private sector in promoting high and inclusive growth and development (Canare et al., 2015).

So it is not hard to understand that domestic entrepreneurs require to invest more time and resources to start a business if the institutional environment that shapes business activities is complicated. Studies show that procedural complexities are significant limiting factors for entrepreneurial growth, in both developing and developed economies. Once the complexities in number and extent of laws and procedures are simplified to promote financial inclusiveness, the time and costs associated with complying to these procedures are reduced all at the same time for an entrepreneur. It is likely that reform measures for lowering the stipulated amount of start-up capital may also be put into place to support potentially active but financially weaker entrepreneurs. This can be a fundamental step towards gearing up local businesses. We, therefore, conjecture that the rise in remittances inflows are likely to influence the entrepreneurial performance positively in the the recipient countries through their favorable impacts on financial institutions and business regulations.

We organize this essay as follows. The next section presents a brief literature review on remittances and entrepreneurship following by section 4.3 describing our empirical approach. In this section, we provide details of the nature of our response variable and the beta re- 
gression technique used in the analysis. Section 4.4 develops some insights into interpreting parameter estimates from beta regression model, and section 4.5 describes the data and variables. Empirical findings are summarized in section 4.6 and section 4.7 concludes.

\subsection{Literature review}

In this section, we briefly review the literature on remittances and their effects on 1) entrepreneurial environment and 2) entrepreneurial activities. These surveys will provide some background for an idea that relates remittances to entrepreneurship, and highlight the significance of our study of the relationship between remittances and level of entrepreneurial performance via their impact on financial institutions and business regulations in remittancerecipient countries.

Financial institutions often seek to commercialize and offer a wider range of financial services to their clients. For the last few decades, large and persistent remittances flows have opened up a scope for lucrative businesses for such institutions. Money transfer is seen as an opportunity to provide potentially very profitable products which can aid in the commercialization process. Not only does handling of remittances seem to promise high returns, but also the opportunities of cross-selling of loans and products such as savings or overdraft facilities. Financial institutions have emphasized the need to integrate lowincome remittance receivers with broader financial services. They are putting extra efforts to change their current 'mode' of operation to efficient services that are accessible to grass roots, safe and reliable, timely, client and service oriented, and moderately priced. There is a high potential for capturing a market share of an underserviced remittances market. Many financial institutions, however, are not in position to take advantage of this opportunity. This is due, in particular, to their limited institutional and system capacities, procedural complexities, limited networks of service outlets, and links to international networks (Sander, 2003). 
A remittance-receiving country's state of financial development may cause remittance receipts to have an important influence on the domestic entrepreneurial performance. When a country's domestic financial system is poorly developed, a large number of households are rationed out of formal credit markets, because the cost of providing credit to them is prohibitively high (Chami et al., 2008). These households are therefore unable to initiate business endeavors.

A significant inflow of remittances, therefore, can contribute to both sides of the aisle. One the one hand, attractive remittances market help prosper the commercialization of financial institutions, thereby forcing them to simplify their rigid legal and bureaucratic procedures. On the other hand, remittances do not only add to the resource base of recipient households and potential entrepreneurs, these transfers also help accumulate assets and collateral in several forms. This is likely to enable creditworthiness of otherwise opaque entrepreneurs. So remittances can back-up potential entrepreneurs to obtain loans from formal financial institutions, thereby empowering them to undertake new and profitable business projects.

Remittances do not only moderate the decline of households' consumption during recessions because of their counter-cyclicality, they also are used to finance the start-up and operating costs of microenterprises that bolster households' income during economic downturns (Shapiro and Mandelman, 2014; Yang, 2005). Lucas (1987) and Rozelle et al. (1999) analyze the growth potential of remittances in a context of capital market imperfections. They find that remittances allow households at the middle-to-bottom end of the wealth distribution to accumulate productive assets and to have access to self-employment and entrepreneurship.

It is argued that capital investment can occur only when the channeling of remittances to such investment is facilitated by financial intermediaries that are able to accept deposits and make them available for lending to agents with investment needs. Consequently, an economy will experience a higher increase in the growth rate if remittances are very large relative to the average 'per entrepreneur' capital stock. If financial markets develop properly, 
it removes financing constraints on both firms' and individuals' development. Remittances might be then viewed as financial flows in search of good investment objects and good financial institutions that together can meet the investment needs of households with family members living abroad (Mundaca, 2008).

As developing economies are characterized by less efficient credit markets, a high level of income inequality and poorly developed capital markets are the biggest concerns for these countries. Therefore, individuals possessing little wealth must forgo potentially profitable investment opportunities (Woodruff and Zenteno, 2001). Studies show that the formation of new businesses as well as the profitability of the existing businesses appear to be affected by financial constraints. Business start-ups are particularly associated with the wealth of potential entrepreneurs if financial constraints limit the scope of entrepreneurial activities. If financial constraints are not important, potential entrepreneurs might decide to start a business based on its expected risk and profitability situations. Also, they can manage outside financing to start the project. On the other hand, if financial constraints are important, however, outside financing may be unavailable or insufficient. This will create a link between the wealth of the potential entrepreneur and the decision to start a business (Paulson and Townsend, 2004).

Many researchers have shown that access to capital is an important factor in entreprenurial development. Using a survey of small firms in Mexico, Woodruff and Zenteno (2001) study the impact of remittances on investment level of Mexican microenterprises. They find the evidence that access to remittance capital does not only lead to higher level of investment, but it also significantly affects the decision to start an enterprise. They argue that savings of returning migrants may be an important source of startup capital for microenterpirses. Their findings show that almost $25 \%$ of the capital invested in microenterprises comes from remitted funds. In a similar study, Dustmann and Kirchamp (2001) employ household level survey data for Turkish migrants to study what activities migrants choose after a return. They show that more than $50 \%$ of the returning migrants are economically 
active after return, and most of them engage in entrepreneurial activities using money saved while working abroad.

By revealing the complementary role of domestic institutions on entrepreneurship, Ashby and Seck (2012) find that remittances lead to greater entrepreneurial endeavors, but this impact is higher in countries with high quality of institutions than in countries with lower quality institutions. They employ unbalanced panel data of more than 100 countries and use the number of newly registered businesses as their measure of entrepreneurship. They argue that remittances support economic development of the low and middle income countries conditional on whether these countries carry out reforms to improve economic and political institutions. Piracha and Saraogi (2011) also support above claim by stating that governments of the remittance recipient countries need to create cohesive policies as an integral part of the development plan to help maximize the benefits of inflow of remittances.

There are, however, some empirical studies that do not find any favorable impact of remittances on either new business ownership or level of investment. Amuedo-Dorantes and Pozo (2006) use household survey data to explore the importance of these monetary inflows in promoting household business ownership in Dominican Republic. Their findings indicate that household remittances receipt lower the households' likelihood of business ownership. They argue that such results may arise due to increase in reservation wages driven by remittances, increase in consumption, or rise in household expenditure on housing, education, and healthcare. Similarly, Chami et al. (2003) employ panel data analysis consisting of 113 countries to show that remittances do not appear to be a significant source of capital for economic development. They claim that because of asymmetric information and economic uncertainty, remittances may create moral hazard problem that can be severe enough to retard economic activities.

Regarding the role of financial constraints in shaping the patterns of entrepreneurship, Paulson and Townshed (2004) use household level survey data from rural and semi-urban Thailand to examine whether wealthier households are more likely to start businesses. They 
provide the evidence that households who eventually start businesses have been accumulating wealth more quickly than households who do not start businesses prior to starting a business- as though they were saving in an effort to overcome an inability to borrow to finance business start-up costs- also underscores the importance of financial constraints. Paulson and Townshed's observation highlight the importance of remittances inflows in the context of developing countries in loosening credit market constraints, thereby facilitating the business endeavor undertaken by potential entrepreneurs.

\subsection{Empirical methodology}

As mentioned earlier, our dependent variable representing 'starting a business' activities across countries is a 'distance to frontier' (DTF) score. The DTF score is a continuous variable and is strictly restricted. By construction, it holds values in the standard unit (open) interval: $(D T F \in(0,1))$. How should one perform a regression analysis in such a situation? One possible choice is to transform the response variable as $\tilde{y}=\log \left(\frac{y}{1-y}\right)$ so that $\tilde{y}$ assumes values in the real line and then apply a standard linear regression analysis. However, this approach creates difficulties in interpreting the parameters as they are interpretable in terms of the mean of $\tilde{y}$, and not in terms of the mean of $y$. Moreover, regressions involving data from the unit interval are typically heteroskedastic. It means they display more variation around the mean and less variation as we approach the lower and upper limits of the standard unit interval. Also, the data restricted to the unit interval such as this exhibits asymmetry, and hence inference based on the assumption of normal distribution can be misleading. In cases such as this, one may appropriately consider the beta distribution as an appropriate distribution for the response variable. As this method resolves the issues emanating from heterogeneity across observations and from lack of normality in model errors, we pool the data and apply the beta regression model to study the impact of remittances on entrepreneurial environment across countries. 
Unlike the case of normally distributed random variable where mean and variance are independent, a beta-distribution involves the variance that can be expressed as a function of the mean. So if a researcher is interested not only in how a covariate influences the expected value of the function, but also the variance, she can appropriately use beta distribution to model the heteroskedasticity. The beta distribution is a continuous probability distribution defined over the unit interval with the beta density expressed as:

$$
f(y \mid \alpha, \beta)=\frac{\Gamma(\alpha+\beta)}{\Gamma(\alpha) \Gamma(\beta)} y^{\alpha-1}(1-y)^{\beta-1} ; \quad 0<y<1 .
$$

Where $\alpha, \beta>0 ; \Gamma()$ denotes the gamma function. In their particular parameterization, Ferrari and Cribari-Neto (2004) formulates the above beta density in the following form:

$$
f(y ; \mu, \phi)=\frac{\Gamma(\mu)}{\Gamma(\mu \phi) \Gamma((1-\mu) \phi)} y^{\mu \phi-1}(1-y)^{(1-\mu) \phi-1} ; \quad 0<y<1 .
$$

with $0 ; \mu<1$, and $\phi>0$, where $\mu$ and $\phi$ are expressed as follows:

$$
\mu=\frac{\alpha}{\alpha+\beta} \quad \text { and } \quad \phi=\alpha+\beta .
$$

The beta-distributed response variable, $\mathrm{y}$, is expressed as $y \sim \mathcal{B}(\mu, \phi)$, such that

$$
E(y)=\mu ; \quad \text { and } \quad \operatorname{Var}(y)=\frac{\mu(1-\mu)}{(1+\phi)} .
$$

Note that the variance is the function of the mean and the parameter, $\phi$. The parameter $\phi$ fulfills the definition of a precision parameter because, for fixed $\mu$, the greater the value of $\phi$, the smaller the variance of the dependent variable. The regression parameters are interpretable in terms of the mean of y. In beta regression models, the mean parameter $\mu \in(0,1)$ of the beta distribution is expressed as a function of covariates. We will see below that $g\left(\mu_{i}\right)=\left(x_{i}^{T} \beta\right)=\eta_{i}$ (a linear predictor); and so $\mu_{i}=g^{-1}\left(x_{i}^{T} \beta\right)$, implying that $\mu_{i}$ is a function of $\beta$, the vector of regression parameters. 
Let $y_{1}, \ldots, y_{n}$ be a random sample representing the DTF scores for starting a business across countries such that $y_{i} \sim \mathcal{B}\left(\mu_{i}, \phi\right) ; i=1, \ldots, n$. Then, to map the linear predictor into the space of observed values on the unit interval, the beta regression model analyzed in this paper using the logit link function is defined as the following:

$$
\operatorname{logitg}\left(\mu_{i}\right)=\log \left(\frac{\mu_{i}}{1-\mu_{i}}\right)=x_{i}^{T} \beta=\eta_{i}
$$

Where $x_{i}=\left(x_{i 1}, \ldots, x_{i k}\right)^{T}$ is a $k \times 1$ vector of explanatory variables or regressors including remittances (see Section 4$), \beta=\left(\beta_{1}, \ldots, \beta_{k}\right)^{T}$ is a $k \times 1$ vector of unknown regression coefficients, and $k<n$. From equation (4.5), we can write

$$
\log \left(\frac{\mu_{i}}{1-\mu_{i}}\right)=\beta_{1} x_{i 1}+\cdots+\beta_{k} x_{i k}=\eta_{i}
$$

In general, $x_{i 1}=1$ for all $\mathrm{i}$ so that the model has an intercept. The main motivation for applying a link function to the regression structure is such that both sides of the regression equation assume values in the real line. Moreover, an appropriate choice of the link function may lead to the best fit of the model. From equations (4.4) and (4.5), we obtain

$$
\operatorname{Var}\left(y_{i}\right)=\frac{\mu_{i}\left(1-\mu_{i}\right)}{(1+\phi)}=\frac{g^{-1}\left(x_{i}^{T} \beta\right)\left[1-g^{-1}\left(x_{i}^{T} \beta\right)\right]}{1+\phi}
$$

This illustrates that the variance of $\mathrm{y}$ is a function of $\mu$. Therefore, the parameterization based on Ferrari and Cribari-Neto(2004) makes the model inherently heteroskedastic. The log-likelihood function is $\ell(\beta, \phi)=\sum_{i=1}^{n} \ell_{i}\left(\mu_{i}, \phi\right)$, where

$\ell_{i}\left(\mu_{i}, \phi\right)=\log \Gamma(\phi)-\log \Gamma\left(\mu_{i} \phi\right)-\log \Gamma\left(\left(1-\mu_{i}\right) \phi\right)+\left(\mu_{i} \phi-1\right) \log y_{i}+\left\{\left(1-\mu_{i}\right) \phi-1\right\} \log \left(1-y_{i}\right)$.

As we can see from above, $\mu_{i}=g^{-1}\left(x_{i}^{T} \beta\right)$, implying that $\mu_{i}$ is a function of $\beta$, the vector of regression parameters. The parameters of the model are estimated by the method of maximum likelihood (ML). 


\subsection{Interpretation of parameter estimates}

How do we interpret the parameter estimates from the beta regression model? In fact, interpretation of parameter estimates in the beta regression model (when logit link is used)is equivalent to a logistic regression in which exponentiated coefficients can be interpreted in terms of odds ratio. By applying the exponential function to both sides in equation (4.6), we obtain

$$
\exp \left(\log \left(\frac{\mu_{i}}{1-\mu_{i}}\right)\right)=\exp \left(\beta_{1} x_{i 1}+\cdots+\beta_{k} x_{i k}\right)
$$

From this expression, the ratio of expected value of DTF score to that of difference to the perfect DTF score can be written as

$$
\frac{\mu_{i}}{1-\mu_{i}}=\exp \left(\beta_{1} x_{i 1}+\cdots+\beta_{k} x_{i k}\right)
$$

Where $\mu_{i}$ is the expected value of DTF (Distance to Frontier) score under initial covariates. Equation (4.8) can be described as the ratio of convergence of an economy toward the frontier relative to its divergence from the frontier or perfect performance. Now, let us assume that $\mu_{i}^{*}$ be the expected value of DTF score if we increase $x_{k}$ by one unit to the right-hand side in (4.8), holding all other regressors unchanged. Under this scenario, the above ratio can be written as

$$
\frac{\mu_{i}^{*}}{1-\mu_{i}^{*}}=\exp \left(\beta_{1} x_{i 1}+\cdots+\beta_{k}\left(x_{i k}+1\right)\right)
$$

Now, dividing equation (4.9) by that of equation (4.8), we obtain the resulting ratio as

$$
\frac{\frac{\mu_{i}^{*}}{1-\mu_{i}^{*}}}{\frac{\mu_{i}}{1-\mu_{i}}}=\frac{\exp \left(\beta_{1} x_{i 1}+\cdots+\beta_{k}\left(x_{i k}+1\right)\right)}{\exp \left(\beta_{1} x_{i 1}+\cdots+\beta_{k} x_{i k}\right)} .
$$


By simplification,

$$
\frac{\frac{\mu_{i}^{*}}{1-\mu_{i}^{*}}}{\frac{\mu_{i}}{1-\mu_{i}}}=\exp \left(\beta_{k}\right) .
$$

The coefficient $\beta_{k}$ in equation (4.11) expresses itself as the log of two ratios each representing the convergence of an economy toward the frontier relative to its divergence from the frontier or perfect performance. It is independent of any particular observation, that is, it does not depend on the particular value of the covariates. The resulting ratio in equation (4.11) quantifies the mean efficiency level by which the remittance-recipient economy is driven up toward the frontier or lowered down from it when the covariate $x_{k}$ is increased by one unit relative to the initial values of all the covariates.

Now, let us consider an example of how we can interpret a coefficient estimate from the beta regression model. Assume that the parameter $\beta_{k}$ is associated with remittances in our beta regression model of entrepreneurial environment given by equation (4.5) such that $\beta_{k}=0.2109$, then, $e^{(0.2109)} \approx 1.235$. So we obtain, from equation (4.11),

$$
\frac{\frac{\mu_{i}^{*}}{1-\mu_{i}^{*}}}{\frac{\mu_{i}}{1-\mu_{i}}}=1.235=\frac{2.47}{2}=\frac{b}{a} .
$$

By simplification, $\mu_{i}=\frac{a}{1+a}=0.66$ and $\mu_{i}^{*}=\frac{b}{1+b}=0.71$.

This is interpreted as follows: "a unit increase in remittances per capita is found to raise the expected efficiency level of the recipient economy from 0.66 to 0.71 in terms of the DTF of starting a business." This implies that the convergence of the remittance-recipient economy is driven up toward the frontier of starting a business from an expected efficiency level of 0.66 to the expected efficiency level of 0.71 on average if the inflow of remittances is increased by one unit relative to the initial value of all covariates. As the frontier represents the perfect level of performance, a positive coefficient with remittances implies that the inflow of remittances leads the economy toward higher level of performance in terms of starting a business. 


\subsection{Data and variables}

The data for this analysis come from the following sources: World Development Indicators (WDI), Doing Business Database of World Bank Group, Heritage Foundation, and Center for International Development at Harvard University (CID). Table 4.1 in Appendix presents a summary descriptive statistics of all the variables employed in this study. Our dependent variable (Distance to Frontier, $\operatorname{DTF} \in(0,1)$ ) is a measure of the level of business environment in a country that quantifies the ease of "starting a business". It is computed by using four component indicators of starting a business, viz., minimum capital requirement (\% of income per capita), number of required procedures, cost to complete each procedure (\% of income per capita), and time required to complete each procedure (calendar days).

Before constructing the DTF score, individual indicator scores are normalized to a common unit by computing a component indicator, $d_{i}$, for a given component, by the following formula.

$$
d_{i}=\frac{M_{i}-y_{i}}{M_{i}-m_{i}} ; \quad 0 \leq d_{i} \leq 1
$$

Where, $i=1,2,3,4 ; M_{i}=$ maximum value for component $\mathrm{i} ; m_{i}=$ minimum value for component $\mathrm{i} ; y_{i}=$ actual value of component $\mathrm{i}$.

To mitigate the effects of outliers in the rescaled data, the maximum is defined as the 95th percentile of the pooled data for all economies and all years for each indicator. The similar procedure is applied to define the minimum performance. In fact, this approach of computing DTF score makes it asymptote to the extreme values 0 and 1 . The composite DTF score is a simple average of DTF scores for these four indicators.

The variable of interest is remittances per capita (in thousands unit) which is obtained by dividing total absolute size of remittances by total population. Remittances are defined as the sum of worker's remittances, compensation of employees, and migrant's transfers. The control variables are chosen by referring to standard entrepreneurship literature. They include logarithm of real GDP per capita, level of education (school enrollment, secondary(\% 
gross)), a measure of institutional quality (business freedom index), urbanization (urban population, $\%$ of total), degree of economic openness (exports, $\%$ of GDP), binary variables for legal origins, and religion variables (\% of population). Note that business freedom index is an overall indicator of the efficiency of government regulation of business that includes even the closing aspects of a business. This index, though correlated with the DTF score of ease of starting a business, is a much broader concept.

The period of analysis covers 2004-2012. The dataset form an unbalanced panel consisting of 133 countries based on the availability of data. The total number of country-year observations is 849 . The dataset is available from the author upon request.

\subsection{Empirical findings}

Before presenting the estimation results, we check on the nature of the data whether the model assumes homoskedasticity. We perform studentized Breusch-Pagan (1979) test by running Ordinary Least Squares (OLS) model. By rejecting the null hypothesis with the test, the model exhibits heteroskedasticity. The use of beta regression model with logit link function, therefore, can contribute to the best fit of the model by addressing heteroskedasticity as well as the asymmetry of the model residuals.

Table 4.1 (see Appendix) presents the major results of our analyses. Column 2 shows the estimates from pooled model. This provides some indication about the direction of impacts of our regressors on the dependent variable. As a first impression, remittances appear to have a positive impact on starting a business. The pooled model, however, may violate the assumption of homogeneity. To account for the heterogeneity in the data, we than estimate a random-effects model along with time-fixed effects controlled. A random-effects model allows the country-specific effects to be random and so the across country variation in the explanatory variables play important role to explain variation in the expected value of the dependent variable. We are not employing a fixed-effects model because some of the 
explanatory variables are time invariant.

The parameter estimates from random-effects model are presented in column 3. The coefficient estimate with remittances appears with a positive sign and is statistically significant at $5 \%$ level. Before resorting to beta regression, we want to emphasize the result that the conventional panel estimation technique indicates a favorable impact of remittances on institutional framework in the recipient country. The results also provide supports for the findings in the literature that the level of education and better institutional quality (business freedom as a proxy here) have a positive impact on entrepreneurial performance of a country. Also, the estimates with urbanization and openness are negative, providing the evidence that in a situation of increasing competition and complexities, starting a new business climate turns out to be harder and becomes very challenging.

As discussed above, with the assumption that our response variable follow betadistribution, we use the beta regression model to alleviate the twin problems arising from violations of homoskedasticity and normality of model errors. Column 4 in Table 4.1 shows parameter estimates from the beta regression model with legal dummy variables included as a part of explanatory variables. We find that the estimate with remittances bears a positive sign and is statistically significant. Clearly, this result reinforces our findings from the pooled and panel estimation that inflow of remittances exhibits a strong positive relationship with entrepreneurial performance in the recipient country measured in terms of starting a business.

Furthermore, as we described in Section 4.4, with the coefficient estimate equal to 0.2109 (see Beta (Model I), Table 4.1) associated with remittance variable, the resulting ratio is computed as $\exp (0.2109) \approx 1.235$. Consequently, from equations (4.11) and (4.12), $\mu_{i}=0.66$ and $\mu_{i}^{*}=0.71$. Hence, the results imply that the convergence of the remittance-recipient economy is driven up toward the frontier of starting a business from an expected efficiency level of 0.66 to the expected efficiency level of 0.71 on average if the inflow of remittances is increased by one unit relative to the initial value of all covariates. As the frontier represents 
the perfect level of performance, the positive coefficient implies that the inflow of remittances leads the economy toward higher level of entrepreneurial performance expressed in terms of starting a business, thereby filling the gap between this economy with that of the economy of the best performance. This positive impact is found to be both statistically significant as well as economically meaningful. Notice that the estimates with other explanatory variables in the model are entirely consistent with the findings in business and entrepreneurship literature. Finally, we replace the legal dummy variables with religion variables as a part of explanatory variables to account for the impact of cultural practices on financial institutions and business environment. These results are presented in column 5 (see Beta (Model II), Table 4.1). The findings from this specification are all consistent with that of beta specification in Model I.

We now assess the robustness of our results by using the length of time necessary to formally set-up and run a domestic, small or medium-sized business as a dependent variable in our regression model. Basically, the length of time required to start a business is considered a crucial indicator of overall business environment in a country. This indicator shows the number of calendar days needed to complete the procedures to legally operate a business. The World Bank's database lists 189 countries in terms of the time required to start a business. For 2014, in first place is New Zealand, with one day. In France and Canada, along with eight other countries, it takes five days. Also, South Korea, along with six other countries, is listed as four days. The United States, with 12 other countries, is listed as six days (Washington Post, May 2015). This scenario illustrates the idea how 'red tape' may hold back small businesses and entrepreneurs even in the context of industrialized economies.

Table 4.2 presents the robustness results. Columns 2 and 3 contain parameter estimates from pooled OLS models, first with religion variables as a part of explanatory variables and then with legal dummies. We find a positive estimate for the coefficient associated with remittances. Now we estimate fixed-effects panel models with robust standard errors. Column 4 shows the resulting estimates with religion variables included. These results reinforce our earlier findings by showing that inflow of remittances significantly reduces the 
time required to start a business. Notice that the size of coefficient estimate with remittances is bigger in absolute term in this model of 'time' in comparison to the previous models of 'ease' of starting a business. The outcomes are similar once we replace religion variables with legal origin variables. We find, as expected, better education and greater business freedom are found to be negatively associated with the length of time required to start a business. Similarly, as discussed above, higher level of national income and economic liberalization do not guarantee an ease of starting a business and may not facilitate the reduction of time required to launch a business. This argument is supported by parameter estimates associated with GDP per capita and economic openness that appear with a positive sign, which are not statistically significant, however.

\subsection{Concluding remarks}

In this essay, we investigated whether remittances enhance the level of entrepreneurial performance in the recipient countries through the ease of starting a business. Specific to our response variable, Distance to Frontier $(D T F \in(0,1))$, that measures absolute quality or level of performance of an economy with regards to starting a business, we analyzed panel data by focusing on beta regression model. The results provide the evidence that remittances can significantly improve entrepreneurial performance in the recipient economy through their favorable impact on financial institutions and business regulations. Our findings show that inflows of remittances are conductive to doing business in terms of the 'ease' and 'time' of starting a business. The results suggest that international money transfers generate positive incentives for both suppliers and demanders of financial services. Such incentives lead to attractive investment climate and thriving small and medium-sized businesses. Though remittances are non-market private transfers, they are useful resources to broaden the scope of mainstream financial system, thereby contributing to the goal of inclusive development in the recipient countries. 


\subsection{Bibliography}

1. Amuedo-Dorantes, C., and Susan Pozo, (2006), Remittance Receipt and Business Ownership in the Dominican Republic, The World Economy, doi: 10.1111/j.1467-9701.

2. Ashby N. J., and Ousmane Seck, (2012), Remittances, Institutional Quality, and Entrepreneurship, Department of Economics and Finance, University of Texas at El Paso, 79968.

3. Canare, T., Alvin Ang, and Ronald U. Mendoza, (2015), Enhancing the Ease of Doing Business in APEC Countries: A Comprehensive Review of Literature, Asian Institute of Management, Rizalino S. Navarro Policy Center for Competitiveness, Working Paper.

4. Chami, R., Adolf Barajas, Thomas Cosimano, Connel Fullenkamp, Michael Gapen, and Peter Monteil, (2008), Macroeconomic Consequences of Remittances, International Monetary Fund, Washington D.C.

5. Chami, R., Connel Fullenkamp, and Samit Jahjah, (2003), Are Immigrant Remittance Flows a Source of Capital for Development?, IMF Working Paper.

6. Cribari-Neto, F., and Achim Zeileis (2012), Beta Regression in R.

7. Doing Business 2015, Going Beyond Efficiency, World Bank Group.

8. Dustmann, C., and Oliver Kirchkamp, (2002), The optimal migration duration and activity choice after re-migration, Journal of Development Economics, Vol. 67 (2002) 351-372.

9. Ferrari, S. L. P., and Francisco Cribari-Neto (2004), Beta Regression for Modelling Rates and Proportions, Journal of Applied Statistics, Vol. 31, No 7, 799-815.

10. Freund, C., and Nikola Spatafora (2008), Remittances, transaction costs, and informality, Journal of Development Economics, 86 (2008) 356366.

11. Grabel, I., (2008), The Political Economy of Remittances: What Do We Know? What Do We Need to Know?, Josef Korbel School of International Studies, University of Denver, Denver, CO 80208, USA. 
12. Lucas, R.E.B., (1987), Emigration to South Africas mines, American Economic Review, $77(3), 313-330$.

13. Mundaca, B. G., (2008), Remittances, Financial Markets Development and Economic Growth: the case of Latin America and Caribbean, Ragnar Frisch Centre for Economic Research University of Oslo, Oslo, Norway.

14. Paolino, P., (2001), Maximum Likelihood Estimation of Models with Beta-Distributed Dependent Variables, Department of Government, The University of Texas at Austin.

15. Paulson, A. L., and Robert Townsend, (2004), Entrepreneurship and financial constraints in Thailand, Journal of Corporate Finance, 10(2004) 229-262.

16. Piracha, M., and Amrita Saraogi, (2011), Motivations for Remittances: Evidence from Moldova, IZA DP NO. 5467.

17. Sander, C., (2003), Capturing a market share? Migrant remittance transfers commercialization of microfinance in Africa., Paper prepared for the Conference on Current Issues in Microfinance, Bannock Consulting.

18. Shapiro, A. F., and Federico S. Mandelman, (2014), Remittances, Entrepreneurship, and Employment Dynamics over the Business Cycle, Working Paper 2014-19.

19. The Washington Post, (2015), http://www.washingtonpost.com/blogs/fact-checker/

20. Woodruff, C., and Rene Zenteno, (2001), Remittances and Microenterprises in Mexico, UCSD and ITESM-Guadalajara.

21. Rozelle, S., J.E. Taylor and A. deBrauw, (1999), Migration, remittances, and agriculture productivity in China, American Economic Review, 89(2), 287-291.

22. Yang, D. (2005)., International migration, human capital, and entrepreneurship: Evidence from Philippine migrants exchange rate shocks, Mimeo, University of Michigan. 


\subsection{Appendix}

Table 4.1: Remittances and starting a business: Pooled OLS, Random-effects (RE), and Beta (ML) estimates.

\begin{tabular}{|c|c|c|c|c|}
\hline \multirow[b]{2}{*}{ Variable } & \multicolumn{3}{|c|}{ Dependent variable: starting a business } & \multirow[b]{2}{*}{ Beta (Model II) } \\
\hline & Pooled OLS & Random-effects $^{\dagger}$ & Beta (Model I) & \\
\hline Remittances & $\begin{array}{r}0.0516^{* * *} \\
(0.0155)\end{array}$ & $\begin{array}{c}0.1383^{* *} \\
(0.0560)\end{array}$ & $\begin{array}{r}0.2109^{* * *} \\
(0.0802)\end{array}$ & $\begin{array}{c}0.1998^{* *} \\
(0.0838)\end{array}$ \\
\hline Log GDP per-capita & $\begin{array}{r}0.0143 \\
(0.0141)\end{array}$ & $\begin{array}{r}0.0106 \\
(0.0404)\end{array}$ & $\begin{array}{c}0.1321^{*} \\
(0.0725)\end{array}$ & $\begin{array}{r}0.0087 \\
(0.0735)\end{array}$ \\
\hline Education & $\begin{array}{r}0.0014^{* *} \\
(0.0002)\end{array}$ & $\begin{array}{r}0.0040^{* * *} \\
(0.0007)\end{array}$ & $\begin{array}{r}0.0057^{* * *} \\
(0.0014)\end{array}$ & $\begin{array}{r}0.0098^{* * *} \\
(0.0013)\end{array}$ \\
\hline Bussiness freedom & $\begin{array}{r}0.0061^{* * *} \\
(0.0004)\end{array}$ & $\begin{array}{r}0.0036^{* * *} \\
(0.0009)\end{array}$ & $\begin{array}{r}0.0354^{* * *} \\
(0.0020)\end{array}$ & $\begin{array}{r}0.0362^{* * * *} \\
(0.0020)\end{array}$ \\
\hline Urbanization & $\begin{array}{r}-0.0003 \\
(0.0003)\end{array}$ & $\begin{array}{r}-0.0006 \\
(0.0008)\end{array}$ & $\begin{array}{r}-0.0013 \\
(0.0016)\end{array}$ & $\begin{array}{r}-0.0045^{* * *} \\
(0.0016)\end{array}$ \\
\hline Openness & $\begin{array}{r}-0.0002 \\
(0.00015)\end{array}$ & $\begin{array}{r}-0.0002 \\
(0.0004)\end{array}$ & $\begin{array}{c}-0.0019^{* *} \\
(0.00087)\end{array}$ & $\begin{array}{r}-0.0003 \\
(0.00086)\end{array}$ \\
\hline Legal origin (Socialist) & $\begin{array}{r}0.0130 \\
(0.0120)\end{array}$ & $\begin{array}{r}-0.0408 \\
(0.0266)\end{array}$ & $\begin{array}{r}0.0399 \\
(0.0622)\end{array}$ & \\
\hline Legal origin (French) & $\begin{array}{r}-0.0667^{* * *} \\
(0.0105)\end{array}$ & $\begin{array}{r}-0.0956^{* * *} \\
(0.0309)\end{array}$ & $\begin{array}{r}-0.3524^{* * *} \\
(0.0529)\end{array}$ & \\
\hline Legal origin (Germany) & $\begin{array}{r}-0.0939^{* * *} \\
(0.0193)\end{array}$ & $\begin{array}{r}-0.1185^{* * *} \\
(0.0346)\end{array}$ & $\begin{array}{r}-0.6732^{* * *} \\
(0.1021)\end{array}$ & \\
\hline Legal origin (Scandinavian) & $\begin{array}{r}-0.0482^{* *} \\
(0.0196)\end{array}$ & $\begin{array}{r}-0.0743^{* *} \\
(0.0323)\end{array}$ & $\begin{array}{r}-0.2458^{* *} \\
(0.1218)\end{array}$ & \\
\hline Catholic & & & & $\begin{array}{r}-0.0014 \\
(0.0011)\end{array}$ \\
\hline Muslim & & & & $\begin{array}{r}-0.0005 \\
(0.0011)\end{array}$ \\
\hline NO CPM & & & & $\begin{array}{r}0.0010 \\
(0.0012)\end{array}$ \\
\hline Constant & $\begin{array}{c}0.1902^{* *} \\
(0.0302)\end{array}$ & $\begin{array}{r}0.1954^{* *} \\
(0.0920)\end{array}$ & $\begin{array}{r}-1.9418^{* * *} \\
(0.1533)\end{array}$ & $\begin{array}{r}-1.9244^{* * *} \\
(0.2118)\end{array}$ \\
\hline Number of countries & 133 & 133 & 133 & 133 \\
\hline Observations & 849 & 849 & 849 & 849 \\
\hline Pseudo $\mathrm{R}^{2}$ & 0.60 & 0.55 & 0.62 & 0.58 \\
\hline
\end{tabular}


Table 4.2: Remittances and time required to start a business: Pooled OLS and Randomeffects (RE) estimates.

\begin{tabular}{|c|c|c|c|c|}
\hline \multicolumn{5}{|c|}{ Dependent variable: time required to start a business* } \\
\hline Variable & Pooled OLS (I) & Pooled OLS (II) & Random-effects $(\mathrm{I})^{\dagger}$ & Random-effects (II) \\
\hline Remittances & $\begin{array}{r}-0.1498^{* * *} \\
(0.0492)\end{array}$ & $\begin{array}{r}-0.1011^{* *} \\
(0.0467)\end{array}$ & $\begin{array}{r}-0.3509^{* *} \\
(0.1785)\end{array}$ & $\begin{array}{c}-0.3399^{*} \\
(0.1852)\end{array}$ \\
\hline Log GDP per-capita & $\begin{array}{r}-0.0054 \\
(0.0353)\end{array}$ & $\begin{array}{r}0.0023 \\
(0.0359)\end{array}$ & $\begin{array}{r}0.0557 \\
(0.0946)\end{array}$ & $\begin{array}{r}0.1107 \\
(0.0986)\end{array}$ \\
\hline Education & $\begin{array}{r}-0.0008 \\
(0.0006)\end{array}$ & $\begin{array}{r}0.0001 \\
(0.0007)\end{array}$ & $\begin{array}{r}-0.0054^{* * *} \\
(0.0015)\end{array}$ & $\begin{array}{r}-0.0058^{* * *} \\
(0.0017)\end{array}$ \\
\hline Bussiness freedom & $\begin{array}{r}-0.0150^{* * *} \\
(0.0011)\end{array}$ & $\begin{array}{r}-0.0163^{* * *} \\
(0.0012)\end{array}$ & $\begin{array}{r}-0.0095^{* * *} \\
(0.0021)\end{array}$ & $\begin{array}{r}-0.0095^{* * *} \\
(0.0021)\end{array}$ \\
\hline Urbanization & $\begin{array}{r}-0.0003 \\
(0.0008)\end{array}$ & $\begin{array}{r}-0.0007 \\
(0.0009)\end{array}$ & $\begin{array}{r}-0.0004 \\
(0.0019)\end{array}$ & $\begin{array}{r}-0.0009 \\
(0.0023)\end{array}$ \\
\hline Openness & $\begin{array}{r}0.0011^{* *} \\
(0.0004)\end{array}$ & $\begin{array}{r}0.0013^{* * *} \\
(0.0004)\end{array}$ & $\begin{array}{r}0.0006 \\
(0.0014)\end{array}$ & $\begin{array}{r}0.0005 \\
(0.0015)\end{array}$ \\
\hline Legal origin (Socialist) & & $\begin{array}{c}-0.0682^{*} \\
(0.0354)\end{array}$ & & $\begin{array}{r}0.0564 \\
(0.0666)\end{array}$ \\
\hline Legal origin (French) & & $\begin{array}{r}-0.0184 \\
(0.0309)\end{array}$ & & $\begin{array}{r}0.0227 \\
(0.0744)\end{array}$ \\
\hline Legal origin (Germany) & & $\begin{array}{r}0.1703^{* * *} \\
(0.0389)\end{array}$ & & $\begin{array}{r}0.1313 \\
(0.0906)\end{array}$ \\
\hline Legal origin (Scandinavian) & & $\begin{array}{r}0.0167 \\
(0.0494)\end{array}$ & & $\begin{array}{r}-0.0433 \\
(0.1137)\end{array}$ \\
\hline Catholic & $\begin{array}{r}0.0011^{* *} \\
(0.0005)\end{array}$ & & $\begin{array}{r}0.0018 \\
(0.0012)\end{array}$ & \\
\hline Muslim & $\begin{array}{r}-0.0015^{* * *} \\
(0.0005)\end{array}$ & & $\begin{array}{r}-0.0013 \\
(0.0012)\end{array}$ & \\
\hline NO CPM & $\begin{array}{r}0.0000 \\
(0.0005)\end{array}$ & & $\begin{array}{l}(0.0005) \\
(0.0012)\end{array}$ & \\
\hline Constant & $\begin{array}{r}2.4182^{* * *} \\
(0.1076)\end{array}$ & $\begin{array}{r}2.4280^{* * *} \\
(0.0832)\end{array}$ & $\begin{array}{r}2.2056^{* * *} \\
(0.2701)\end{array}$ & $\begin{array}{r}2.0955^{* * *} \\
(0.2117)\end{array}$ \\
\hline Number of countries & 133 & 133 & 133 & 133 \\
\hline Observations & 849 & 849 & 849 & 849 \\
\hline $\mathrm{R}^{2}$ & 0.396 & 0.371 & 0.336 & 0.293 \\
\hline
\end{tabular}


Table 4.3: Summary Statistics ${ }^{\dagger}$

\begin{tabular}{|c|c|c|c|c|}
\hline Variable name & Mean & Standard deviation & Minimum & Maximum \\
\hline Remittances (per Capita) & 164.38700 & 253.9280 & 0.0085783 & 3278.427 \\
\hline Log of GDP (in constant US\$) & 3.655701 & 0.699582 & 2.175323 & 4.935141 \\
\hline Education (school enrollment, secondary ( $\%$ gross $)$ ) & 80.74391 & 27.39928 & 9.16514 & 148.8852 \\
\hline Business Freedom & 68.42485 & 15.12071 & 28.8 & 100 \\
\hline Urbanization ( $\%$ of population) & 59.58145 & 22.02652 & 10.376 & 100 \\
\hline Openness ( $\%$ of exports) & 42.14135 & 26.89204 & 6.802359 & 225.5611 \\
\hline Catholic ( $\%$ of total population) & 34.07585 & 37.33502 & 0 & 96.9 \\
\hline Muslim (\% of total population) & 19.49688 & 33.27627 & 0 & 99.7 \\
\hline Protestant ( $\%$ of total population) & 13.02191 & 23.00406 & 0 & 97.8 \\
\hline No_CPM (other religions, $\%$ of total population) & 33.40536 & 32.85775 & 0.100003 & 100 \\
\hline Legal origin (British) & 0.2685512 & 0.4434671 & 0 & 1 \\
\hline Legal origin (Socialist) & 0.2167256 & 0.4122569 & 0 & 1 \\
\hline Legal origin (Germany) & 0.0530035 & 0.2241726 & 0 & 1 \\
\hline Legal origin (French) & 0.4110718 & 0.4923183 & 0 & 1 \\
\hline Legal origin (Scandinavian) & 0.0506478 & 0.2194067 & 0 & 1 \\
\hline Distance to Frontier $(\mathrm{DTF} \in(0,1))$ & 0.7343214 & 0.1727787 & 0.1389 & 0.9995 \\
\hline
\end{tabular}

†Data set contains 133 countries; \# of observations is 849 . 


\section{Chapter 5}

\section{Conclusion, Policy Implications, and}

\section{Future Research}

\subsection{Summary}

Remittances have become one of the largest international flows of financial resources in the global economy for the last three decades. For many developing economies, remittances exceed official development assistance, portfolio flows from financial markets, and even foreign direct investment. Because of the tremendous size of remittances accompanied with their stability, counter-cyclicality, and unrequited nature, they should be expected to have significant political economy effects on the recipient economies. In this dissertation, we focused our analysis on the relationship between remittances and the quality of institutions.

In Chapter 2, we investigated whether inflows of remittances help or hurt the quality of domestic governance and tried to identify the potential channel of influence. The econometric analysis identifies remittances as a potential factor to affect the incentives faced by households and the government in remittance-receiving economies. With respect to household behavior, our results indicate that the rise in remittances are associated with an increasing demand for private goods but a decreasing share of public goods in household consumption. 
Concerning the government motivation, we find a significant negative association between remittances and government consumption expenditure. This critical result implies that remittances induce the government to substitute the provision of public goods for remittances. Our empirical study, therefore, provide evidence of governmental free-riding on public goods provision in the presence of remittances. The econometric analysis suggests that substitution of resources occurs in a nonlinear fashion across countries; and leads to higher government corruption, deterioration of rule and law, and inferior regulatory quality; thereby causing a loss in public welfare.

Another measure of institutional quality is the extent of financial inclusion in an economy which we took up in Chapter 3. The banking and financial services are commonly identified within the nature and category of public goods. Therefore, the availability of such vital services to a nation's population efficiently and without discrimination is a major goal of financial inclusion public policy. We analyzed the impact of international remittances flows on the demand for deposit instruments and the extent to which such instruments are used to save money. Our analysis at country level indicates that remittances inflows have an adverse impact on financial inclusion by causing a significant negative impact on the use of saving instruments. On the other hand, remittances are found to have no impact on the demand for such instruments.

Such findings remain robust even when we analyze disaggregated data at the rural level across countries; no such supports are found for the urban sector, however. These results suggest that rural regions in developing countries have been continuously facing higher costs of financial services and deficiency of modern economic and physical infrastructures. Because of existing financial barriers, people are still unable to access and use financial products and services offered by formal financial institutions. It is also possible that recipients of remittances in rural regions are attracted more towards informal methods of finance for various reasons, thereby causing a decline in the extent of using deposit instruments, or amount of savings in particular. 
Our third measure of institutional quality is the degree of business environment and regulatory framework. In Chapter 4, we examined the impact of remittances on the quality of business regulations by using a variable called the ease of starting a business. The results provide the evidence that remittances can contribute to entrepreneurial performance in the recipient economy through their favorable impact on financial institutions and business regulations. The results suggest that international money transfers generate positive incentives for both suppliers and demanders of financial services. Such incentives lead to attractive investment climate and thriving businesses. Though remittances are non-market private transfers, they are useful resources to broaden the scope of mainstream financial system, thereby contributing to the goal of inclusive development in the recipient countries.

\section{$5.2 \quad$ Policy implications}

In precise terms, the first essay in Chapter 2 shows that net increase in public welfare due to remittances is lower than potential size. So by worsening the quality of political institutions, remittances can have an adverse impact on growth and economic development. Similarly, the second essay in Chapter 3 suggests that remittances deteriorate inclusive finance. This may impede the goals of poverty alleviation and inclusive development. In contrast to the negative consequences of remittances observed so far, the analysis in third essay in Chapter 4 illustrates that remittances can broaden the scope of mainstream financial system by their favorable impact on financial institutions and business environment. Overall, the impact of remittances on institutional quality is, therefore, ambiguous. This ambiguity arises due to specific incentives generated by remittances inflows on the particular aspect of institutional quality under consideration.

The first policy implication of our findings is that active public-private partnership can be an important mechanism to maximize benefits from remittances and to avoid potential misallocation of public resources in the presence of remittances. Such collaborative efforts 
can significantly contribute to productive investment, both in private and public sectors. Recently, international organizations, financial agencies, and many governments have increased their focus on how to channelize flows of remittances through formal financial institutions. We believe that the results of this analysis are expected to contribute to these global efforts to redirect remittances inflows from current uses toward empowering households to increase their access to financial instruments and services. Also, uses of remittances toward this end are expected to avoid the potential negative consequences of governmental free-riding on the provision of public goods and services. The rise in remittances has, thus, brought both opportunities and challenges for the recipient countries in leveraging these financial transfers for poverty alleviation, entrepreneurial growth, and greater economic prosperity.

\section{$5.3 \quad$ Future research}

We suggest a number of potential avenues for future research. First, we used aggregated data on remittances to analyze their effects on institutional quality. Recently, economists have emphasized the use of worker's remittances as the best measure of remittances to draw valid inferences. It would be interesting to see whether above findings remain robust with this measure of remittances. Second, it would be important issue to explore what items or provisions of public goods suffer governmental free-riding by extending our analysis to incorporate those government expenditures. Third, our panel data analysis in Chapter 2 involves coastal area as an instrumental variable for remittances which is a time invariant variable. The results would be more realistic and convincing if a time variant instrument were used instead. Similar instrumental variables strategy is desirable to address the issue of endogeneity in Chapters 3 and 4 as well. Finally, it would also be useful to identify and employ a more comprehensive measure of financial inclusion, and a precise measure of entrepreneurial environment in the analysis. 